\title{
Zircon Geochronology of Ash Beds in the Marcellus Shale of the Appalachian Basin
}

Jessica M. Hayward

West Virginia University

Follow this and additional works at: https://researchrepository.wvu.edu/etd

\section{Recommended Citation}

Hayward, Jessica M., "Zircon Geochronology of Ash Beds in the Marcellus Shale of the Appalachian Basin" (2012). Graduate Theses, Dissertations, and Problem Reports. 138.

https://researchrepository.wvu.edu/etd/138

This Thesis is protected by copyright and/or related rights. It has been brought to you by the The Research Repository @ WVU with permission from the rights-holder(s). You are free to use this Thesis in any way that is permitted by the copyright and related rights legislation that applies to your use. For other uses you must obtain permission from the rights-holder(s) directly, unless additional rights are indicated by a Creative Commons license in the record and/ or on the work itself. This Thesis has been accepted for inclusion in WVU Graduate Theses, Dissertations, and Problem Reports collection by an authorized administrator of The Research Repository @ WVU. For more information, please contact researchrepository@mail.wvu.edu. 
Zircon Geochronology of Ash Beds in the Marcellus Shale of the Appalachian Basin

Jessica M. Hayward

Thesis submitted to the

Eberly College of Arts and Sciences

at West Virginia University

in partial fulfillment of the requirements

for the degree of

Master of Science

In

Geology

Jaime Toro, Ph.D., Chair

Dr. Timothy Carr, Ph.D.

Dr. Amy Weislogel, Ph.D.

Department of Geology and Geography

Morgantown, West Virginia

2012

Keywords: Marcellus Shale; Onondaga Limestone; Zircon; SHRIMP-RG

Copyright 2012 Jessica M. Hayward 


\section{ABSTRACT \\ Zircon Geochronology of Ash Beds in the Marcellus Shale of the Appalachian Basin Jessica M. Hayward}

Volcanic ash horizons, produced by arc magmatism in the Acadian orogeny, are interbedded with the Marcellus Shale and Onondaga Limestone of the Appalachian basin. Zircon grains from the ash layers are suitable for SIMS U-Th-Pb geochronology due to their resistant behavior against weathering and ability to record age of the eruptions.

A total of 24 Tioga ash layers within cores of the Middle Devonian Marcellus and Onondaga from six wells located in West Virginia and Pennsylvania were collected for $\mathrm{U}-\mathrm{Pb}$ dating. The ash horizons were recognized as thinly laminated tuffaceous shale with graded beds of white mica and pyrite, ranging in thickness between $0.5-14 \mathrm{~cm}$. Zircon grains were extracted from 16 of the ash horizons and analyzed using the Sensitive High Resolution Ion Micro Probe Reverse Geometry (SHRIMP-RG) method.

The zircon grains mounted on epoxy rounds were inserted in the SHRIMP RG to calculate $\mathrm{Pb}, \mathrm{U}$, and Th concentrations and obtain precise age constraints. ${ }^{206} \mathrm{~Pb} /{ }^{238} \mathrm{U}$ ages of all ash layers range between $380.9 \pm 2 \mathrm{Ma}$ to $403.8 \pm 4 \mathrm{Ma}$ (Frasnian to Emsian). Zircons containing inherited cores reflect ages of greater than $1.1 \mathrm{Ga}$ and are interpreted to originate from the regional basement. In some cases, zircons on the same ash horizon produced ages ranging from 390 to $400 \mathrm{Ma}$. With no evidence of $\mathrm{Pb}$ loss, it is interpreted that zircons reflect the longevity of the magmatic system and the younger age clusters represent eruption ages. Three distinct age groups are found from examination of population density plots including major peaks at 384.7, 390.9, and 394.95 Ma.

The age distribution over the foreland basin shows that the base of the Marcellus is diachronous. The ages of the lowermost ash horizons dated are mapped on the six well locations showing an age distribution trend. The base of the Marcellus is $402.1 \mathrm{Ma}$ in a well in northwestern West Virginia and becomes progressively younger to the southeast. In our well closest to the Appalachian front, the basal Marcellus is about $380.9 \mathrm{Ma}$. The

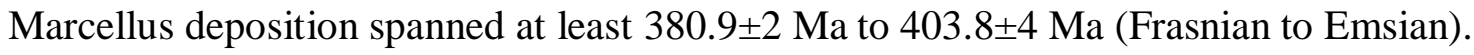

Rare earth element and trace element analyses show that the zircons originate from one source, with multiple eruptions occurring from 383.4 Ma to 402.85 Ma. The zircons are interpreted to originate from a continental granitoid origin, which is consistent with the concept of continental arc magmatism. The direction of the source is from the southeast with respect to the foreland basin, consistent with at the assumed paleo-wind directions in the Middle Devonian time. 
TABLE OF CONTENTS Page

ACKNOWLEDGEMENTS

LIST OF FIGURES

INTRODUCTION 1

STUDY AREA 3

GEOLOGIC BACKGROUND 4

$\begin{array}{ll}\text { METHODOLOGY } & 9\end{array}$

STRATIGRAPHY AND ASH DESCRIPTIONS 15

$\begin{array}{ll}\text { Stratigraphy } & 15\end{array}$

$\begin{array}{ll}\text { Ash Descriptions } & 20\end{array}$

ZIRCON ANALYSIS 25

RARE EARTH ELEMENT ANALYSIS 41

Trace Element Plots $\quad 41$

Rare Earth Element (REE) Concentration Plots 49

DISCUSSIONS AND CONCLUSIONS

Age Data $\quad 52$

Foreland Basin $\quad 54$

$\begin{array}{lr}\text { Source } & 57\end{array}$

REFERENCES

$\begin{array}{lr}\text { APPENDIX } 1 & 62\end{array}$ 


\section{ACKNOWLEDGEMENTS}

I would like to thank Dr. Jaime Toro, Dr. Amy Weislogel, and Dr. Timothy Carr for continual support and funding for my thesis project at West Virginia University. Their guidance was especially important in completing this study and preparing me for my future endeavors. I would also like to thank Joe Wooden at the USGS SHRIMP Lab at Stanford University for his exceptional knowledge and aid for the age dating process. Special thank you to Energy Corporation of America, Petroleum Development Corporation, EQT Corporation, Enerplus and CORELAB for access to core samples. More specifically, thank you to Pete Sullivan for access to the ECA Whipkey core and Pat Rush from CORELAB. Thank you to the WVU Advanced Energy Initiative for funding. Lastly, I would like to thank my incredible family and friends for their everlasting support during the completion of this thesis and in every aspect of my life. 
Figure 1. Study area within the Appalachian basin. 3

Figure 2. Paleogeography during the Middle Devonian. 4

Figure 3. Cross section of the regional tectonism during the Acadian orogeny. 5

Figure 4. Schematic stratigraphic cross section during the Middle Devonian. $\quad 7$

Figure 5. Schematic diagram showing oblique convergence during the Acadian orogeny. 7

Figure 6. Relevant stratigraphic column of the study area. 8

Figure 7. Zircon location of all ashes on three mounts. 10

Figure 8. Transmitted Light Microphotography and Scanning Electron Microscope Cathodoluminescence (SEM-CL).

Figure 9. Schematic diagram of SHRIMP RG including labels of design. 12

$\begin{array}{lr}\text { Figure 10. SHRIMP RG laboratory mass analyzer. } & 12\end{array}$

Figure 11. Type Log for Marcellus, Onondaga and Mahantango formations. 16

Figure 12. Overall cross section from A- A' including six well locations EQT 511391, 19 Goff \#55, Armstrong \#1, St. Whipkey \#1, Coldstream 1MH and Winner 4-8.

Figure 13. Winner 4-8 core Ash \#3. Displays three cyclic graded beds with pyrite, each 20 fining upward.

Figure 14. Winner 4-8 core Ash \#4 displaying very coarse white mica crystals.

Figure 15. Winner 4-8 core Ash \#1 displaying fine grained pyrite crystals.

Figure 16. Coldstream $1 \mathrm{MH}$ core Ash \#4 displaying graded bed of white mica and fossil hash

Figure 17. Isotopic ratios ${ }^{207} \mathrm{~Pb} /{ }^{206} \mathrm{~Pb}$ vs. ${ }^{238} \mathrm{U} /{ }^{206} \mathrm{~Pb}$ for 12 zircons from Ash \#5 of the 26 Coldstream \#1 well.

Figure 18. Weighted means plot of 11 zircons from Coldstream \#1 Ash \#5. 26

Figure 19. Concordia diagram displaying Goff \#55 well location ash horizon two. 27

Figure 20. Goff \#55 Ash 2, Grain 1 dated shown in Transmitted Light Microphotography (Left) and SEM-CL (Right) displaying grain damage 28

Figure 21. Goff \#55 Ash \#2 Concordia diagram with zircon outlier eliminated due to high Uranium concentrations. 
Figure 22. Average ${ }^{206} \mathrm{~Pb} /{ }^{238} \mathrm{U}$ age of 14 zircon crystals in Goff \#55 core,

Figure 23. U-Pb Concordia diagram plot of 13 inherited zircons Grenville in age

Figure 24. All wells showing ash numbers and depths. Ash thickness in inches included. 32

Figure 25. Probability density plot of all zircons dated removing outliers below $370 \mathrm{Ma} 33$ and above $425 \mathrm{Ma}$.

Figure 26. Cross section of six wells including ${ }^{206} \mathrm{~Pb} /{ }^{238} \mathrm{U}$ ages to appropriate ash layers. 35

Table 1. Compacted and decompacted sedimentation rates.

Table 2. Black Nose of the Atlantic Ocean black shale sedimentation rates study.

Figure 27. Location of Blake Nose of the Atlantic black shale sampling locations.

Figure 28. TOC (wt\%) vs. sedimentation rates in $\mathrm{m} / \mathrm{Ma}$.

Figure 29. U/Yb ratio versus $\mathrm{Hf}$ (ppm). Zircons plot above MORB field.

Figure 30. Geochemical discriminant diagrams for zircons.

Figure 31. Continental field outlined by Grimes et. al, 2007 with all zircons from this study plotted against $\mathrm{U} / \mathrm{Yb}$ vs. Hf (ppm).

Figure 32. Eu/Eu*v. Hf (ppm) plots all zircons below Eu/Eu* ratio of 1.

Represents negative europium anomaly.

Figure 33. Trace elements $\mathrm{Y} / \mathrm{Yb}$ versus $\mathrm{Th} / \mathrm{U}$ display the zircon fractionation trend during the crystallization process.

Figure 34. $\mathrm{Yb} / \mathrm{Gd} v \mathrm{~s}$. Th/U ratios of all zircons.

Figure 35. U/Ce vs. Th (ppm) plot shows difference between metamorphic rocks or anatectic melts vs. magmatic rocks.

Figure 36. Ce/Sm vs. Hf (ppm) shows points plotting beneath the Lower Limit Peninsular range pluton line.

Figure 37. Winner 41 Ash 4 REE zircon concentrations diagram.

Figure 38. Rare earth element concentrations for ocean crust zircon normalized to $\mathrm{C} 1$ chondrite

Figure 39. Coldstream Ash 1 REE zircon concentrations diagram.

Figure 40. Age distribution of the lowermost ashes of the Marcellus 


\section{INTRODUCTION}

The Middle Devonian Marcellus Shale and Onondaga Limestone units distributed throughout the Appalachian basin are being extensively studied due to the emerging unconventional shale gas play in the Marcellus Shale. Understanding the depositional environments and tectonic settings of the Onondaga and Marcellus formations gives insight to the geologic history and geographic extent of the organic-rich source rock that fuels natural gas deposits throughout the basin.

Volcanic ash horizons, produced by arc magmatism in the Acadian orogen, are interbedded with the Marcellus Shale and Onondaga Limestone. Zircon grains from the ash layers are suitable for SIMS U-Th-Pb geochronology due to their resistant behavior against weathering and ability to record age of the eruptions. If the zircon crystals are dated using this method, several conclusions can be made about the depositional history and tectonism in the Appalachian basin during the Acadian orogeny. The ages can be used to create time markers for stratigraphic correlation, identify major eruptions, and to understand the distribution and timing of deposition between the Onondaga Limestone and Marcellus Shale.

In this study individual concordant ${ }^{206} \mathrm{~Pb} /{ }^{238} \mathrm{U}$ ages from zircon crystals were obtained using the Sensitive High-Resolution Ion Micro Probe Reverse Geometry (SHRIMP RG) Method completed at Stanford University. Twelve to eighteen spots on individual zircons were analyzed to acquire average ages per ash horizon. Sixteen ash horizons found distributed through six cores were dated and correlated throughout western Pennsylvania and West Virginia. A rare earth element analysis and trace element compositions was also completed to help interpret whether there were several sources of arc magmatism during the Acadian orogeny. Defining an age constraint between ash horizons can provide insight to sedimentation rates within the Marcellus. 
Obtaining the absolute age of the Marcellus Shale in different parts of the basin will help determine whether or not deposition was synchronous or diachronous, providing insight to the depositional setting. These ages will be further interpreted to define a time span between ash horizons providing estimates of the rate of sedimentation of black shale. Correlating the ash beds between well locations can describe major eruption events that occurred during the Acadian orogeny. The trace element composition and rare earth elements that exist in the ash layers will help deduce whether there were one or many sources of volcanism. 


\section{STUDY AREA}

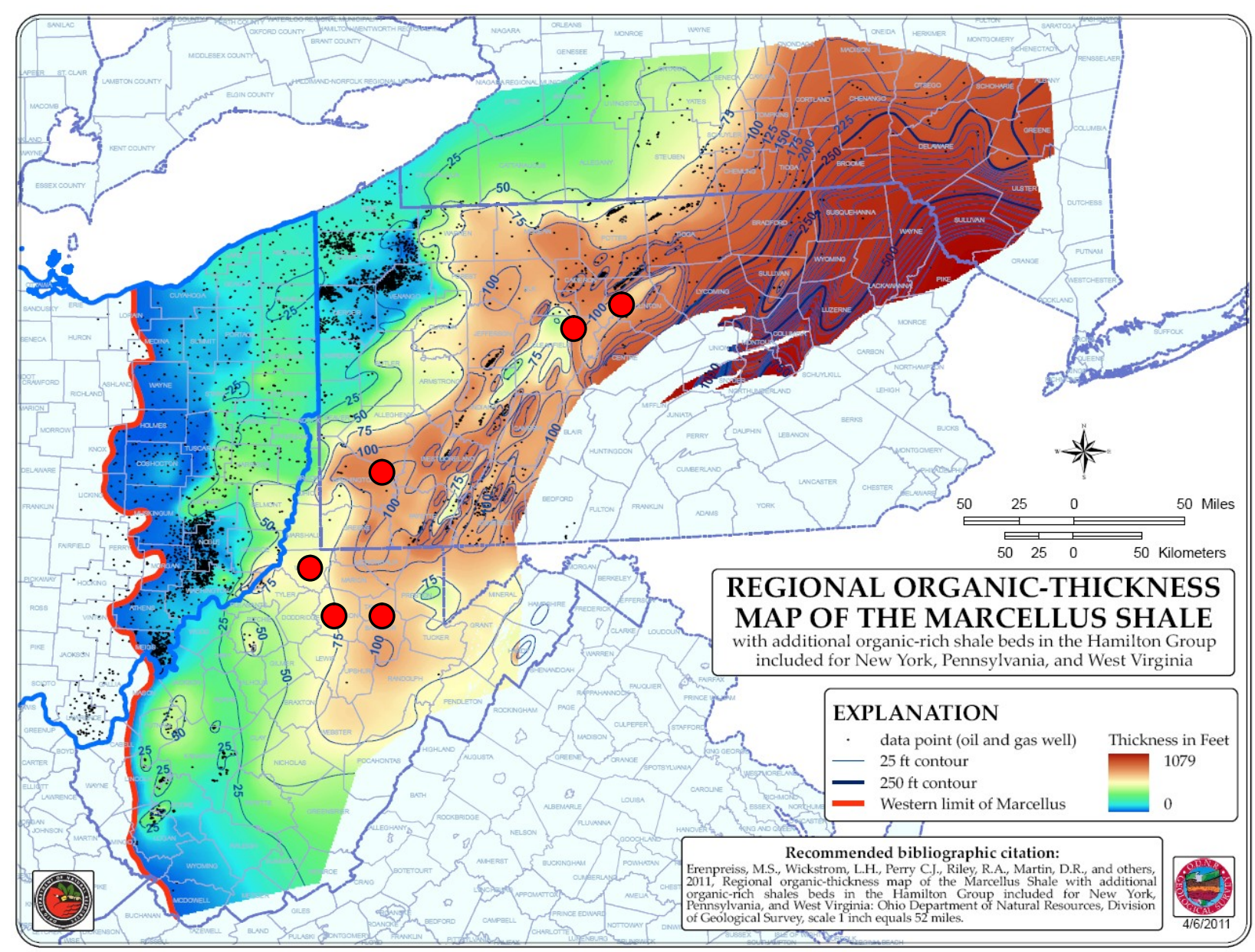

Figure 1. Study area within the Appalachian basin. Well locations in red. (taken from Erenpreiss et al., 2011)

The study area includes six counties located in northern West Virginia and western

Pennsylvania. Three cores were extracted from Wetzel County by EQT, Harrison County by

PDC, and Taylor County, West Virginia by PDC. Three Pennsylvania cores were drilled in

Greene County by ECA, Clearfield County by ECA, and Clinton County by Enerplus (Figure 1). 


\section{GEOLOGIC BACKGROUND}

The Acadian orogeny persisted from 403 to 325 million years ago with several episodes of tectonic subsidence and quiescence. Continued subduction of the Avalonian tectonic plate underneath the northeastern portion of Laurentia caused subsidence of an adjacent foreland basin and regional arc volcanic events (Ettensohn, 2004). The foreland basin was largely flooded by an epicontinental sea containing large deltas and alluvial deposits providing the setting for deposition of the Marcellus and Onondaga formations. Volcanism is recorded from New York to southern portions of the Appalachian basin. Ash-fall accumulated within the basin and was deposited as tuffaceous ash beds within the Marcellus Shale and Onondaga Limestone Formations. During the time of deposition, the atmospheric circulation and wind direction was flowing to the northwest below the equator in reference to Middle Devonian paleogeography of North America (Parrish, 1982). Figure 2 illustrates the paleogeography at the time of Marcellus deposition. Plate convergence was oblique in the northwest direction at a paleolatitude around 25 to 35 degrees south of the equator (Ver Straeten, 1994).

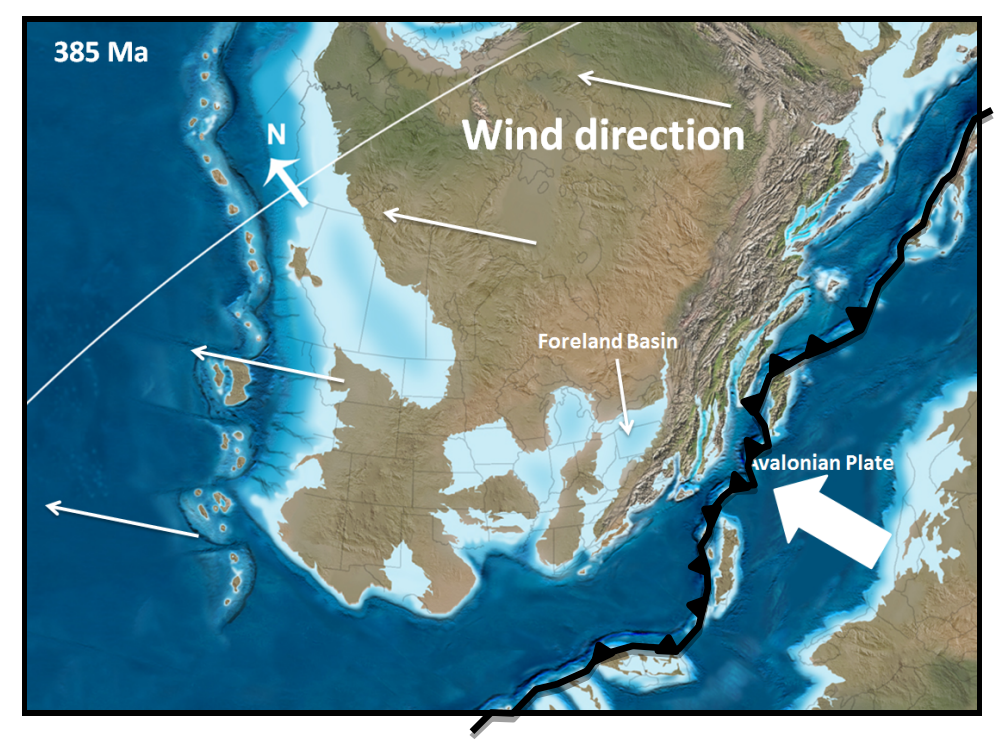

Figure 2. Middle Devonian (385 Ma) paleogeography of North America during the time of Marcellus deposition. (Edited from source Ron Blakey, NAU Geology, 2010) 
Figure 3 is a cross section depiction of the regional tectonism during the Acadian Orogeny. Ash-fall tephra is interpreted to have sourced to the east of the foreland basin. Volcanism is proposed to originate from the mountain chain that extended from Newfoundland to Alabama persisting from Late Silurian to Devonian (Ver Straeten, 2010).

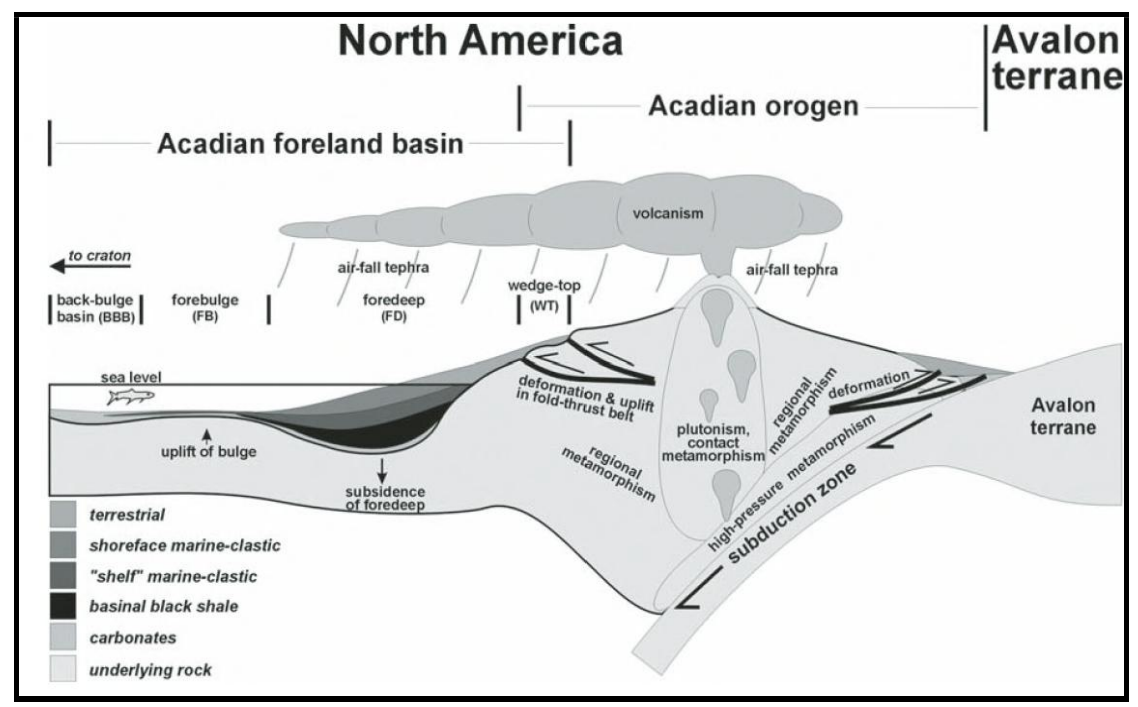

\section{Figure 3. Cross section of the regional tectonism during the Acadian Orogeny (Ver Straeten, 2010).}

As many as 80 or more bentonite ash beds were deposited during the Lower to Middle Devonian (Lochkovian-Eifelian), but only 8 of the total ashes are found within the Tioga Kbentonite cluster (Ver Straeten, 2004). The Tioga K-bentonite cluster occurs in the upper portion of the carbonate dominated Onondaga Formation and basinwide equivalents, and in the lower portions of the marine organic-rich black-shale-dominated Marcellus Shale. The ashes are distinguished by tan layers containing phenocrysts such as biotite or white mica, implying that the beds are of volcanic origin (Ver Straeten, 2004). Many of the ashes are thin, only a few centimeters thick and can be observed in outcrop and wells. Ash beds exhibit physical reworking of ash material from turbidity occurring in a shelf environment (Ver Straeten, 2004). All of the ash beds described in core exhibit graded bedding, with coarser white mica grains at the base 
progressively grading upward to finer grains. The graded bedding is attributed to falling ash that occurred during deposition. Pyrite is distributed throughout the ashes, typically found in higher concentrations towards the base of the ash layer.

The foreland basin that was developed during the orogenic loading was oriented northeast to southwest. Four major successions of deposition occurred during the Acadian Orogeny, allowing distinct basinal black shales, major carbonates, and unconformities to form (Ettensohn, 1987). One of these black shales that accumulated during an overdeepening period or increased subsidence was the Marcellus Shale. Figure 4 is a schematic stratigraphic section from eastcentral New York to north-central Ohio. Four tectophases are represented to occur between the Devonian and Mississippian time periods (Ettensohn, 2004). The second tectophase resulted in the clastic wedge including the Onondaga Limestone and the Hamilton Group which is subdivided into the Mahantango Shale and Marcellus Shale. The development of regional unconformities was associated with collision events, while widespread carbonate deposition was attributed to tectonic quiescence.

Figure 5 displays the distribution of the clastic wedges shed onto the North American craton during the Acadian orogeny. The three major clastic wedges shown include the Early and Middle Devonian (E), Catskill (C), and Pocono-Price (P). The first tectophase includes the Early/Middle Devonian clastic wedge collision and mostly affects areas such as Maine and the Canadian maritime provinces. The Catskill wedge occurred during the second tectophase and represents the southward migration of deformation that affected the New York promontory. The last Pocono-Price wedge had continuing effects during the third and fourth tectophase that occurred during the Late Devonian and Early Mississippian. Deposition of the Marcellus Shale and Onondaga Limestone occurred on the western margin of the Catskill clastic wedge. 


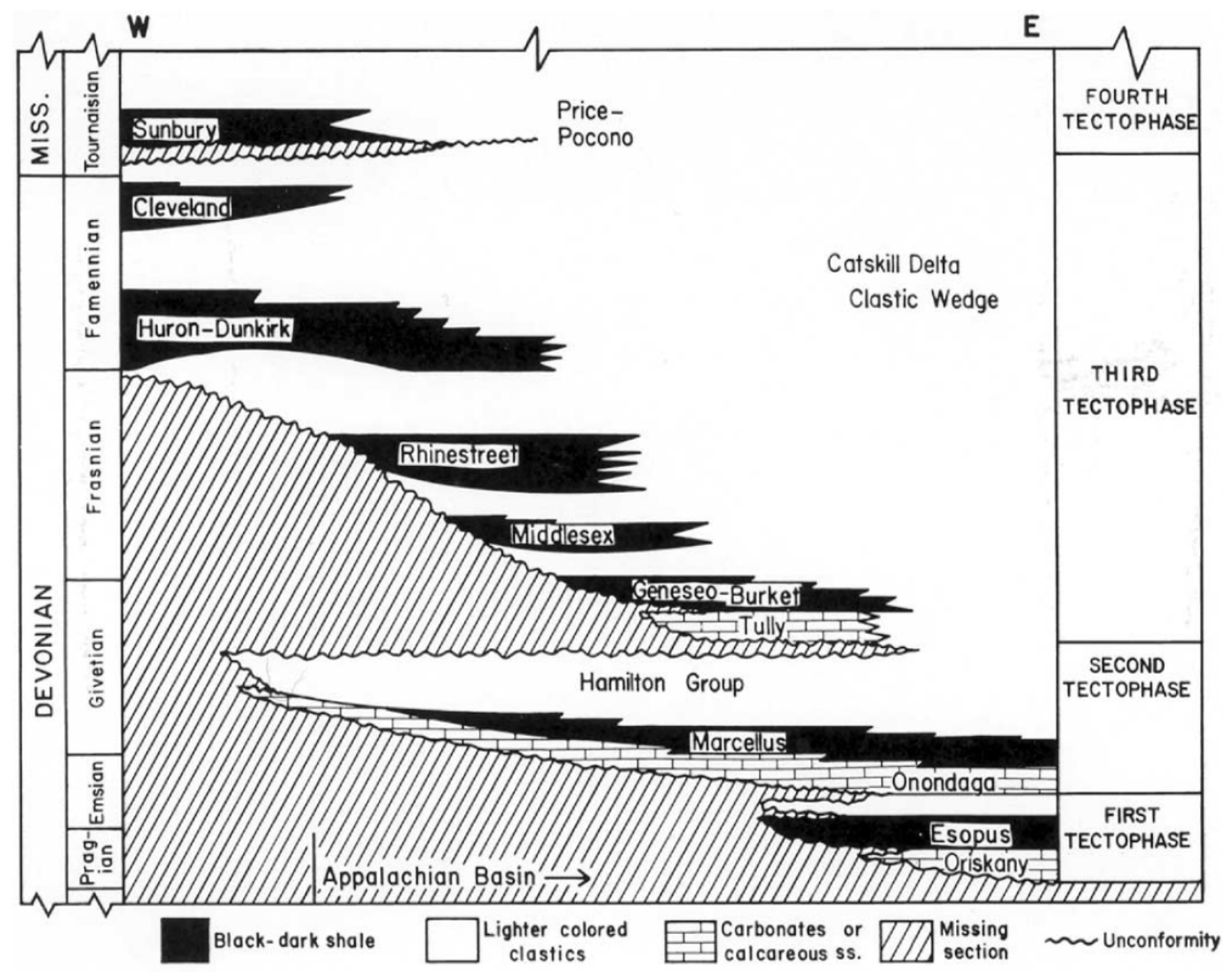

Figure 4. Schematic stratigraphic cross section of the four tectophases that developed during the Devonian and Missisippian time periods (Ettensohn, 2004).

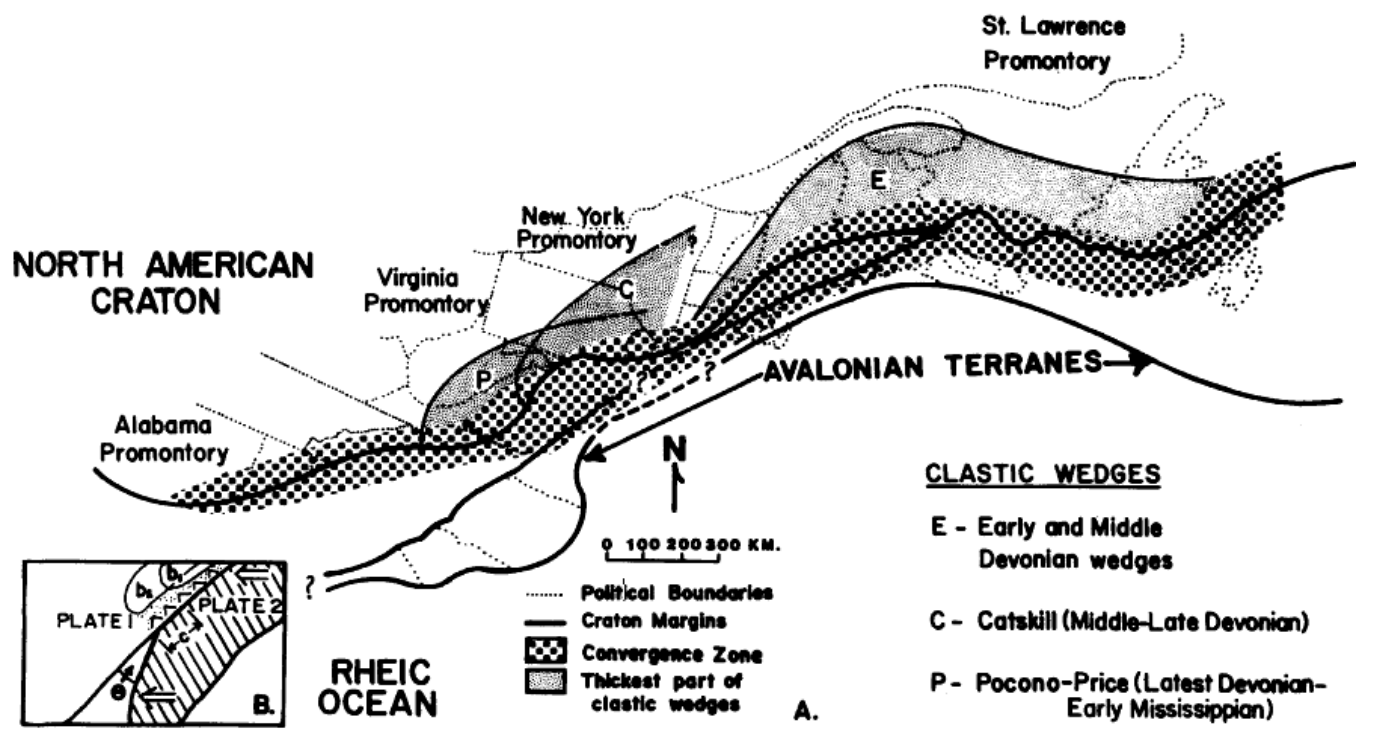

Figure 5. Schematic diagram showing the oblique convergence between the Avalonian terranes and southeastern margin of Laurentia during the Acadian orogeny (Ettensohn, 1987). 


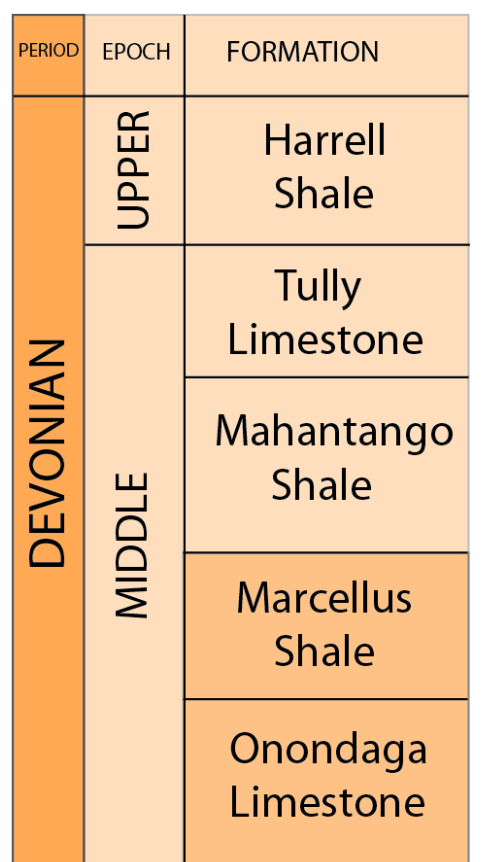

Figure 6. Relevant stratigraphic column of the Study Area
The resulting formations that will be discussed for the purpose of this study are the Onondaga Limestone deposited during tectonic quiescence, and the Marcellus Shale deposited during increased subsidence. Figure 6 illustrates these formations in stratigraphic succession in relation to overlying formations such as the Mahantango Shale, Tully Limestone, and Harrell Shale. The Harrell Shale is dark gray laminated shale, which includes the Tully Limestone at the base, with a total relative thickness between 140-300 feet (Geologic Map Legends, 1968).

The Hamilton Group that was deposited during the second tectophase previously described includes the Marcellus Shale and the Mahantango Shale. The thickness of the Mahantango

Shale ranges over the basin from 0-250 feet, which typical relative thicknesses in this study area of up to 150 feet. The Marcellus Shale is recognized as organic rich black and gray shale, devoid of oxygen during deposition, with sparse records of fossil existence. Average thickness in this study area for the Marcellus Shale is between 50-140 feet. The top of the Onondaga Limestone is interpreted to be a transgressive surface leading into Marcellus deposition, with an average relative thickness of 150-180 feet (Lash, 2008). 


\section{METHODOLOGY}

Ashes from six cores were acquired from several petroleum companies including Petroleum Development Corporation (PDC), Energy Corporation of America (ECA), Enerplus, EQT Corporation, and CORELAB. The 24 ash horizons were recognized as thinly laminated tuffaceous shale ranging in thickness between 0.5 and 14 centimeters. Fining upward graded beds of white mica and pyrite are a characteristic feature of the ash beds described in the six cores. The ash horizons are reworked and dense, with high concentrations of pyrite. Sixteen ash horizons out of 24 were chosen to extract zircon crystals for the U-Pb dating process.

The zircons extraction process includes a series of removal techniques including crushing, gravity separator Gemini Table, sieves (60 mesh and 100 mesh), Frantz magnetic barrier separator, and heavy liquid separation with methylene iodide (MEI). The first step in the zircon extraction process is to crush and grind the ash layers. The ash layers are crushed using a rock hammer and laboratory disc mill. Once the ashes are reduced to small particles, the Gemini Table is used to separate lighter minerals from the heavier minerals. Grains are sieved to a 60 mesh $(250 \mu \mathrm{m})$ and then prepared with a Frantz magnetic barrier separator that splits zircons from other ferromagnetic impurities. $20 \%$ nitric acid is used to remove pyrite. The zircons may be separated in a final step of heavy liquid separation with methylene iodide (MEI), which will cause zircon to sink to the bottom, while lighter minerals float to the top. Zircons are then picked from the sample to be prepared for the dating process under an optical microscope and then mounted on an epoxy mold.

The Uranium-Lead dating analysis was completed by the USGS - Sensitive High Resolution Ion Micro Probe Reverse Geometry (SHRIMP RG) method at Stanford University facility. Samples are initially prepared and mounted on a $25.4 \mathrm{~mm}$ cylindrical epoxy mold to 
surround the zircon grains. The zircons are aligned in rows surrounding a standard sample R33 with a known age of 419 Ma shown in Figure 7 on Mounts \#1, 2, 3.

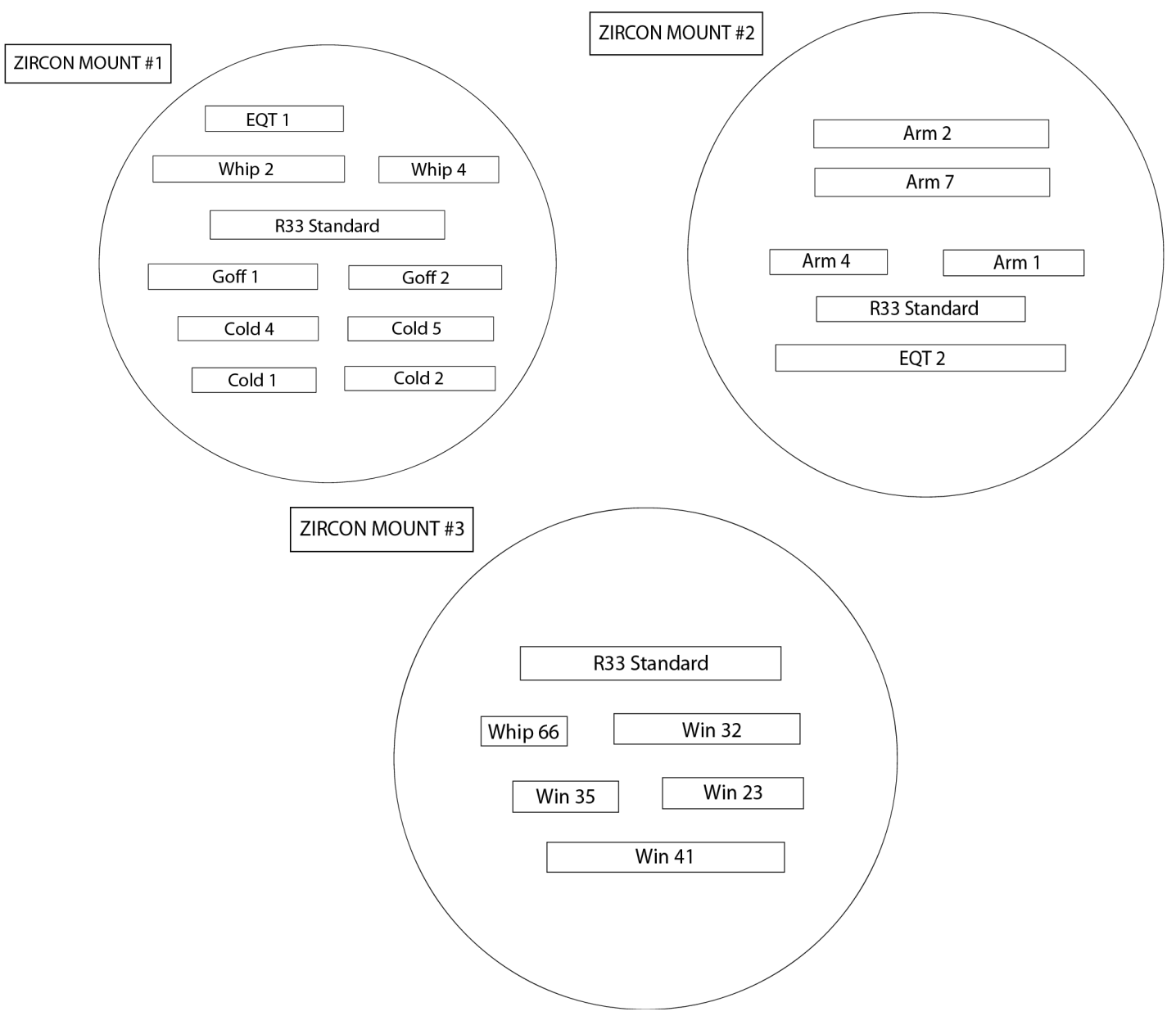

Figure 7. Zircon location of all ashes on three mounts displaying their location in relation to the Standard and other ashes.

The sample is then polished and thoroughly cleaned in an EDTA solution and de-ionized water to allow the application gold in a Denton sputter coater. Before placing the epoxy into the SHRIMP RG, the zircon grains are imaged by Transmitted Light Microphotography and Scanning Electron Microscope - Cathodoluminescence (SEM-CL) to visualize internal features (Figure 8). Figure 8 displays Goff \#55, Ash 2 at a depth of 7231.24 feet. The SEM-CL image includes the number of grains that were dated and their location that the primary ion beam was situated. 

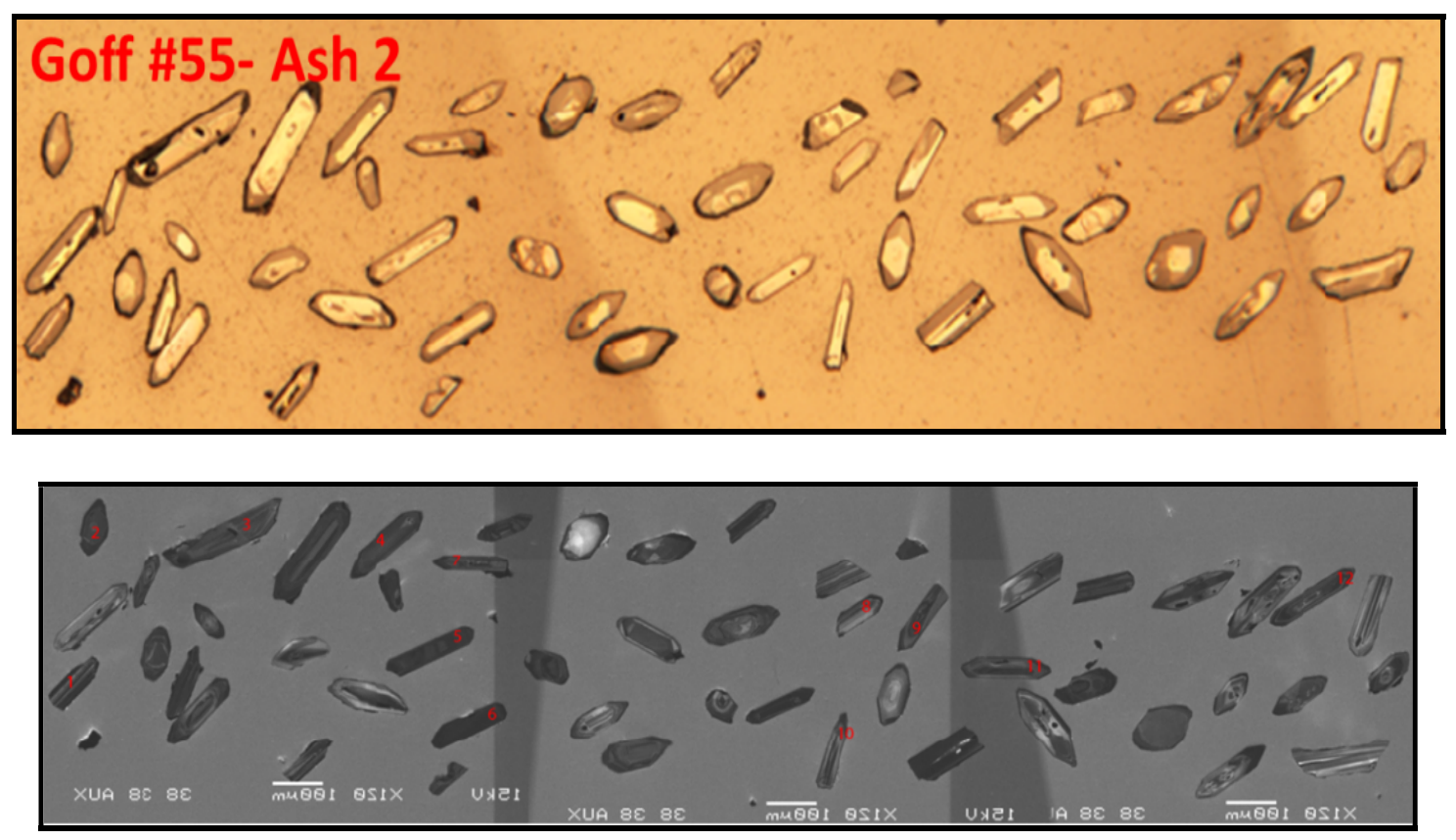

Figure 8. Upper image captured by Transmitted Light Microphotography. Lower image captured by Scanning Electron Microscope - Cathodoluminescence. Red numbers show analyzed spots.

To begin the dating process in the SHRIMP RG, the epoxy round is placed in a sample chamber near the primary column which produces the primary $\left(\mathrm{O}_{2}\right)^{1-}$ ion beam. The source chamber location is shown as the Sample Lock in Figure 9, which displays a SHRIMP RG schematic diagram including all the contents of the machine (SHRIMP RG, 2011). The primary ion beam is focused to a 10 to $30 \mu \mathrm{m}$ diameter on the surface of the zircons at chosen locations. The beam will cause secondary ions to sputter from the sample in the direction of the QQH chamber which will redirect the ions through the magnetic sector. The secondary ions are focused, filtered and measured according to their energy and mass. Detectors found in the collector portion of the SHRIMP RG machine will measure concentrations of Uranium, Lead, and Thorium species. $\mathrm{Zr}, \mathrm{Hf}, \mathrm{Si}, \mathrm{O}, \mathrm{H}$ and rare earth elements are collected and measured as well. 


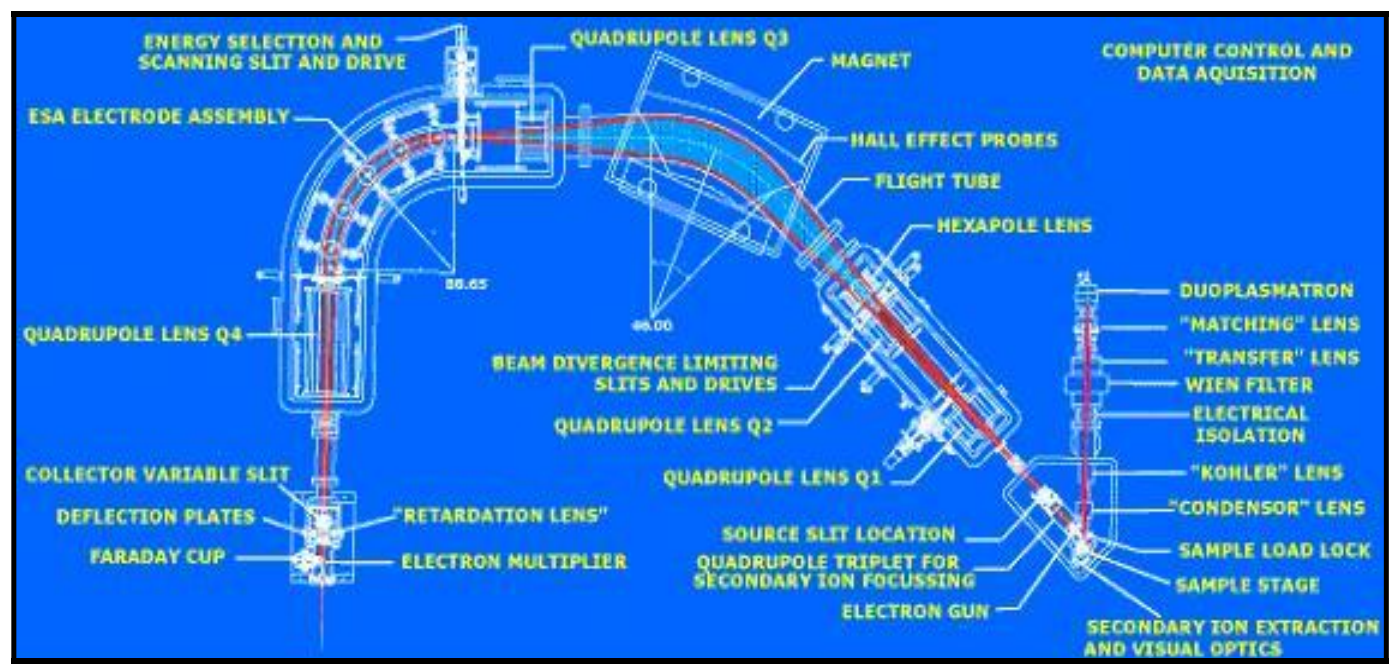

Figure 9. Schematic diagram of SHRIMP RG including labels of each part of the SHRIMP RG design. (SHRIMP RG, 2012).

All of the measurements were then collected and processed using the software package SQUID 1.03 (Ludwig, 2001). Figure 10 displays the computer technology used at the SHRIMP RG laboratory.

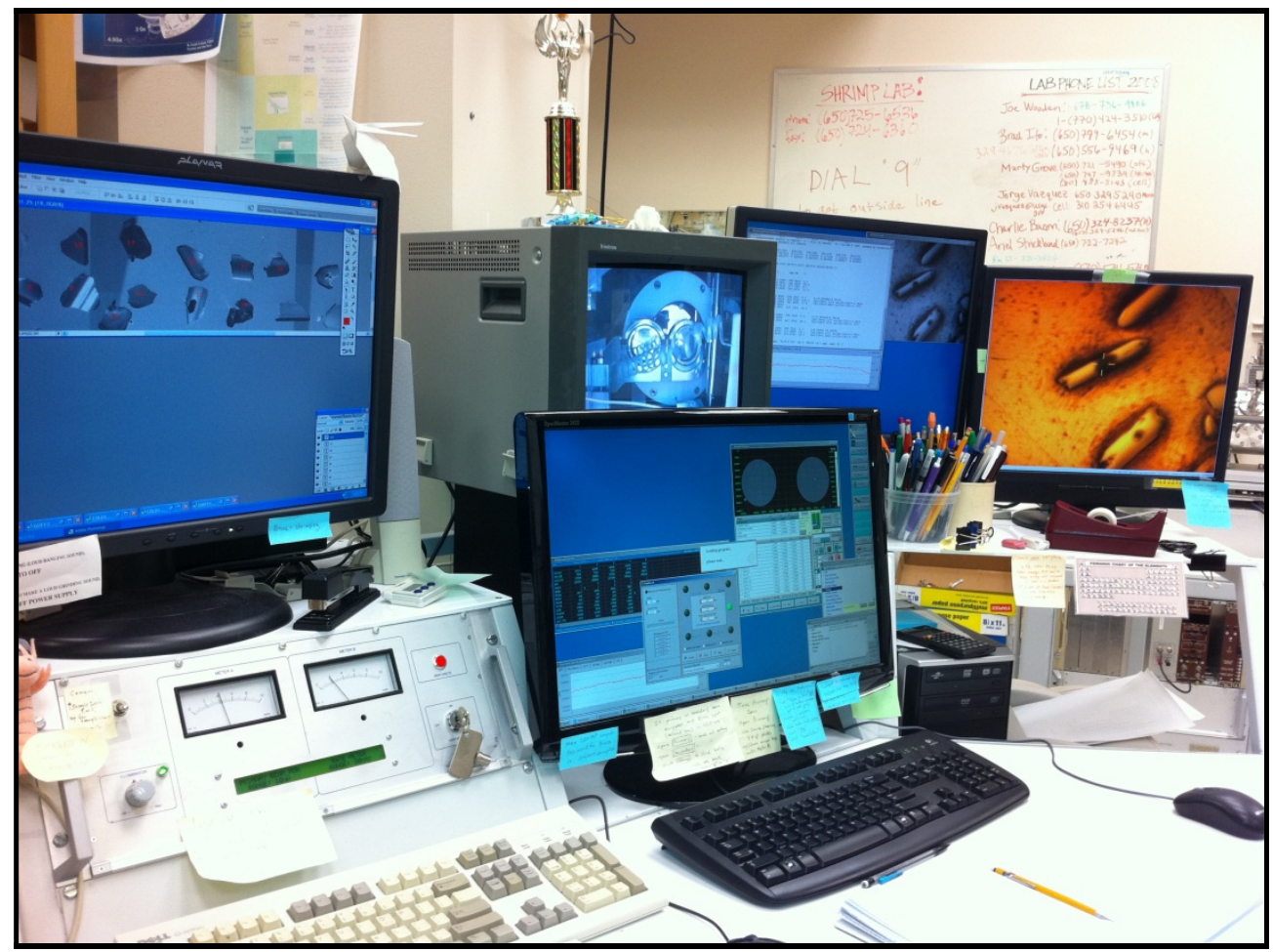

Figure 10. SHRIMP RG laboratory mass analyzer technology displaying spot locations on specific zircon grains. 
All of the monitors were used to choose spot locations on the zircons and collect all of the data that is compiled to calculate isotopic ratios. Isotopic ratios were reduced using ISOPLOT to then create reported ages for each zircon (Ludwig, 2001). The ages are based on histogram plots of the weighted mean ${ }^{207} \mathrm{~Pb}$-corrected ${ }^{206} \mathrm{~Pb} /{ }^{238} \mathrm{U}$ age plots.

Important precautions must be considered when using the SHRIMP RG method for dating volcanic ashes. Ages produced may not be reliable if the primary ion beam is not situated correctly on the surface of the zircon crystal. Zircons are not representative of eruption ages if they have been subjected to lead loss or contain an inherited core. Zircons are subjected to lead loss when the grains are damaged by radiation from decay of uranium within the grains. Radiation damage will distort the crystal lattice, causing easier pathways for lead to diffuse from the crystal and it is most prevalent in zircons with high U concentrations. The SEM-CL images are effective in displaying grains that have cracks or damaged crystal lattices. SEM-CL images was used in the analysis to choose grains before dating that seem to have moderate uranium concentrations and lack of damaged grains. To avoid disrupted grain behavior, grains that are unclear or contain cracks are not dated during the dating process. To minimize the effects of lead loss, the primary ion beam is placed away from the outer surfaces of the grains, which may contain increased concentrations of uranium.

Inherited cores are common in zircons of volcanic rocks and do not represent the true age of the volcanic rock, but relate to the age of the basement. Original zircon xenocrysts become the core for new zircon overgrowth. Different portions of the grain will yield different ages based on the location of the core within the zircon. Inherited cores are common in ash deposits due to the incorporation of country rock into the magma chamber (Bowring and Schmitz, 2003). Zircons that seem to have visible internal spherical cores are avoided due to the risk of inheritance. In the 
Tioga ash samples, zircons with inherited cores tend to be equant in shape, while entirely new volcanic zircons are often elongated needles. The primary ion beam should not be placed directly in the center of the inherited cores, but on the outer edges to date the overgrowth age.

Trace element analyses for Rare earth elements (REE), P, Y, Hf, Th, and U in zircons were analyzed simultaneously with the $\mathrm{U}-\mathrm{Pb}$ isotope analysis. These measurements were collected and compiled into REE concentration plots per each ash horizon and trace element plots including Eu/Eu* vs. Hf, Yb/Gd vs. Th/U, U/Ce vs. Th, U/Yb vs. Hf, Y/Yb vs. Th/U, Yb vs. Y, Ce/Sm vs Hf, and Ce/Sm vs. Yb/Gd. 


\section{STRATIGRAPHY AND ASH DESCRIPTIONS}

\section{Stratigraphy}

The Onondaga and Marcellus formations are the two formations of focus in this study interval. Extensive research has been completed to characterize the sedimentology and depositional geometry of Devonian basin including the Onondaga and Marcellus formations and has been documented in published literature (Sexton, 2011; Boyce, 2010; Johnson et al., 1985; Werne et al., 2002; Sageman et al., 2003; Authur and Sageman, 2004; Bartholomew and Brett, 2007; Ver Straeten, 2007; Brett et al., 2007; Lash and Engelder, 2011). For the purpose of this study, a general introduction to sequence stratigraphy will be presented for comparison to the six well locations from western Pennsylvania and northern West Virginia.

The Onondaga Limestone is described as a very fine grained to crystalline, light to dark brownish gray, somewhat argillaceous and cherty limestone (Fettke, 1961). The paleontological study completed shows that the Onondaga Limestone contains fossils including trilobites, corals, brachiopods, crinoids and trace fossils (Lindholm, 1969). The Onondaga varies in thickness across the Appalachian basin, but can generally be correlated across from New York to Virginia to central Ohio (Ver Straeten, 2007). Deposition of the Onondaga Limestone ceased due to a basin-wide rapid transgression and the deposition of the Marcellus Shale (Lash and Engelder, 2011). Eight of the sixteen total ash horizons dated were found to exist in the Onondaga Limestone of the six wells in this study. The ashes are located in the uppermost several feet of the Onondaga Limestone. Figure 11 displays a type log with a gamma ray interpretation of the Onondaga Limestone found in Armstrong \#1 well in Taylor County, WV. Ash \#7 was found at 7788.5 feet, only 7 feet from the top of the Onondaga Limestone at 7781 feet. The type log is consistent with the lithology description given by Fettke, 1961. 


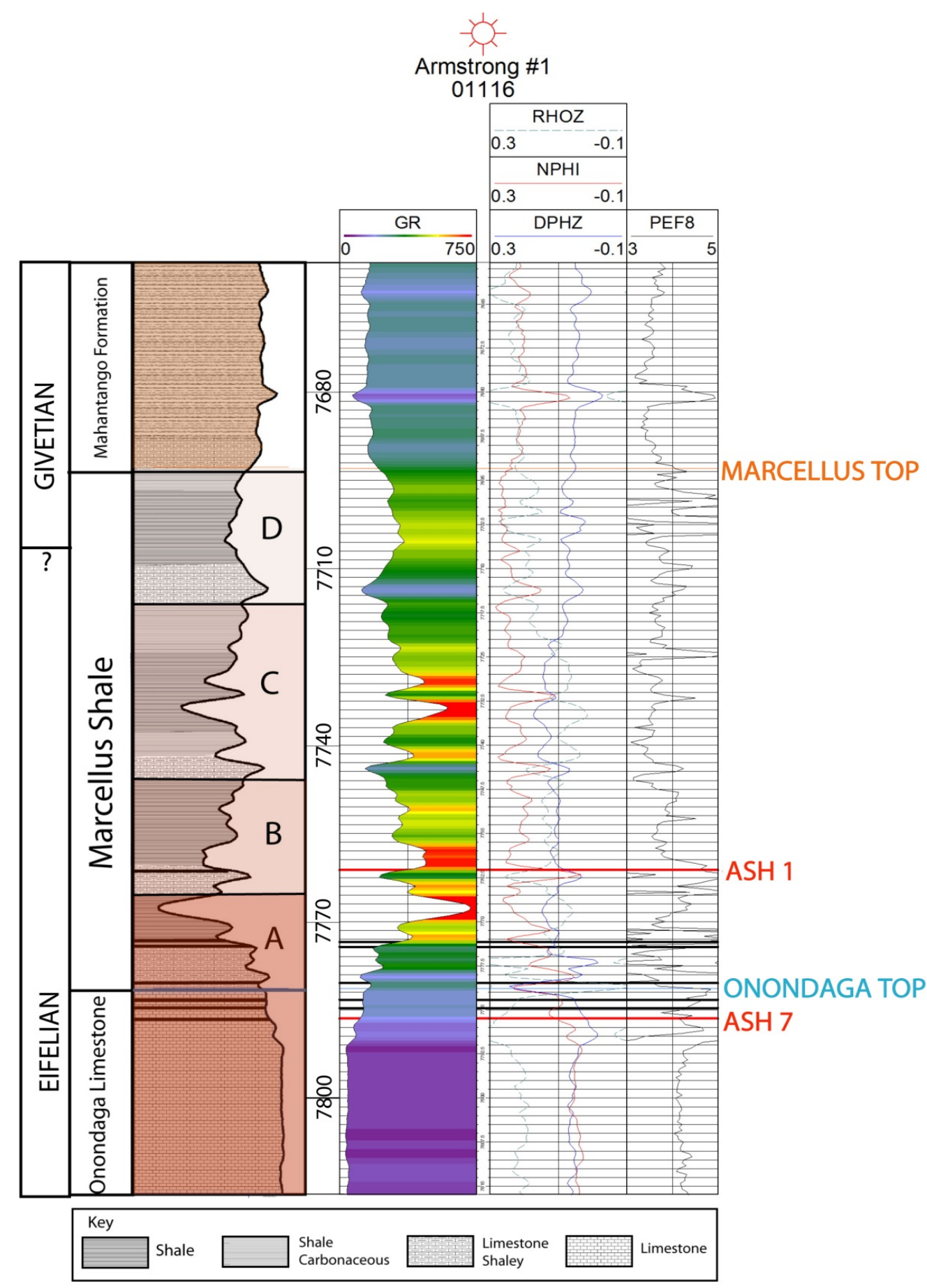

Figure 11. Type Log for Marcellus, Onondaga and Mahantango formations. The Marcellus interval is coarsening upward from black shale to limey shale units. Marcellus is shown separated into four parasequences, A, B, C, D. The top of each parasequence is marked by the base of the limey unit. Black lines are ashes that have not been dated and red lines are dated ashes. Ash 1 is 403.8 $\pm 4.0 \mathrm{Ma}$ and Ash 2 is 402.1 \pm 1.8 Ma. Log tracks include GR-Gamma Ray in API, RHOZ -Bulk density in $\mathrm{g} / \mathrm{cm}^{3}$, NPHI - neutron porosity in v/v_decimal and DPHZ - density porosity v/v_decimal. 
The Marcellus Shale varies greatly across the Appalachian basin in thickness and lithology. The Marcellus Shale has two subgroups including the Union Springs and Oatka Creek formations. The Union Springs formation in western Pennsylvania and northern West Virginia is a highly organic, calcareous mudstone containing abundant skeletal lags (Sagemen et al., 2003). The Oatka Creek formation changes over the basin from New York to West Virginia as a fossiliferous limestone and dark shale, to a dark grey and black shale interval (Ver Straeten and Brett, 2006). Figure 11 displays the type log including the Marcellus Shale up to the overlying Mahantango Formation. The Marcellus interval is shown separated into four parasequences A, B, C, D. The top of each parasequence is marked by the base of a limey unit. The overall interval is coarsening upward from black shale to limey shale units, then overlain by the Mahantango Shale. This method of separating four parasequences is consistent with the Lash and Engelder, 2011 sequence stratigraphic interpretation of transgressive and regressive systems tracts. Each parasequence represents an overall regression. Maximum regressive surface chosen by Lash and Engelder, 2011 are placed at the gamma-ray minimum, while maximum flooding surfaces are placed at a gamma-ray peak, which is a short distance above the maximum regressive surface. All of the ashes found in the Marcellus Shale in the six wells fall into the parasequence A, which is the base of the Marcellus Shale, except for Ash \#1 in the Armstrong \#1 well which falls in parasequence B.

An overall cross section of six wells including EQT 511391, Goff \#55, Armstrong \#1, St. Whipkey \#1, Coldstream 1MH and Winner 4-8 are shown in Figure 12. Twenty four ashes are drawn at depth with the dated ashes in light blue and the non-dated ashes in black. A gamma ray color fill in rainbow displays a correlation between well locations. High API values above 370 are shown in red. These areas represent zones of extremely black, organic rich shale. API values 
ranging from 190-290 in green represent black shale units. API values in purple between 0-120 in this particular cross section are limey to limestone units. 8 of the 16 dated ashes are located at the top of the Onondaga Limestone and 8 are found in the base of the Marcellus Shale. 

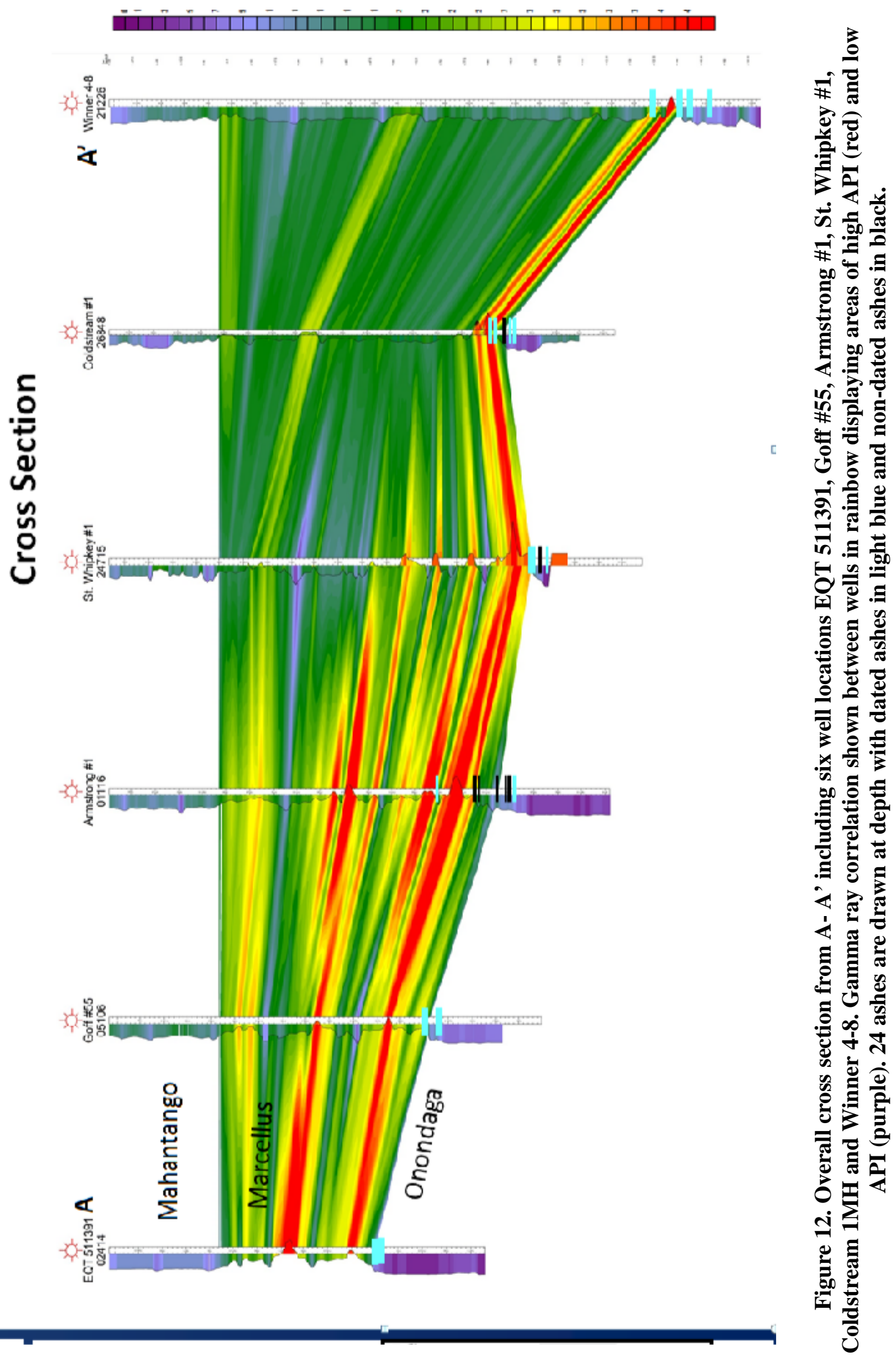


\section{Ash Descriptions}

All ash horizons range in thickness from 0.24-5.51 inches with an average of 1.8 inches in thickness. Key characteristics that distinguish ash from shale include abrupt contacts, graded bedding, pyrite, white mica, and fossil hash surfaces. A diagnostic feature for ash layers includes graded bedding attributed to either falling ash through the water column or turbidity flow. An example of this feature is shown in Figure 13, which displays the Winner 4-8 core Ash $\# 3$ at 1.57 inches thick. The image on the top in Figure 13 allows visualization of three cyclic graded ash beds that are fining upward. The image on the bottom in Figure 13 enhances and outlines the contacts between the three graded beds within the Winner 4-8 Ash \#3 layer at a depth of 8035.4 feet. The top and base of the ash is outlined in yellow displaying a sharp contact between ash and shale. At the base of the Winner 4-8 Ash \#3 layer a pyrite bed with coarser pyrite crystals is visible.

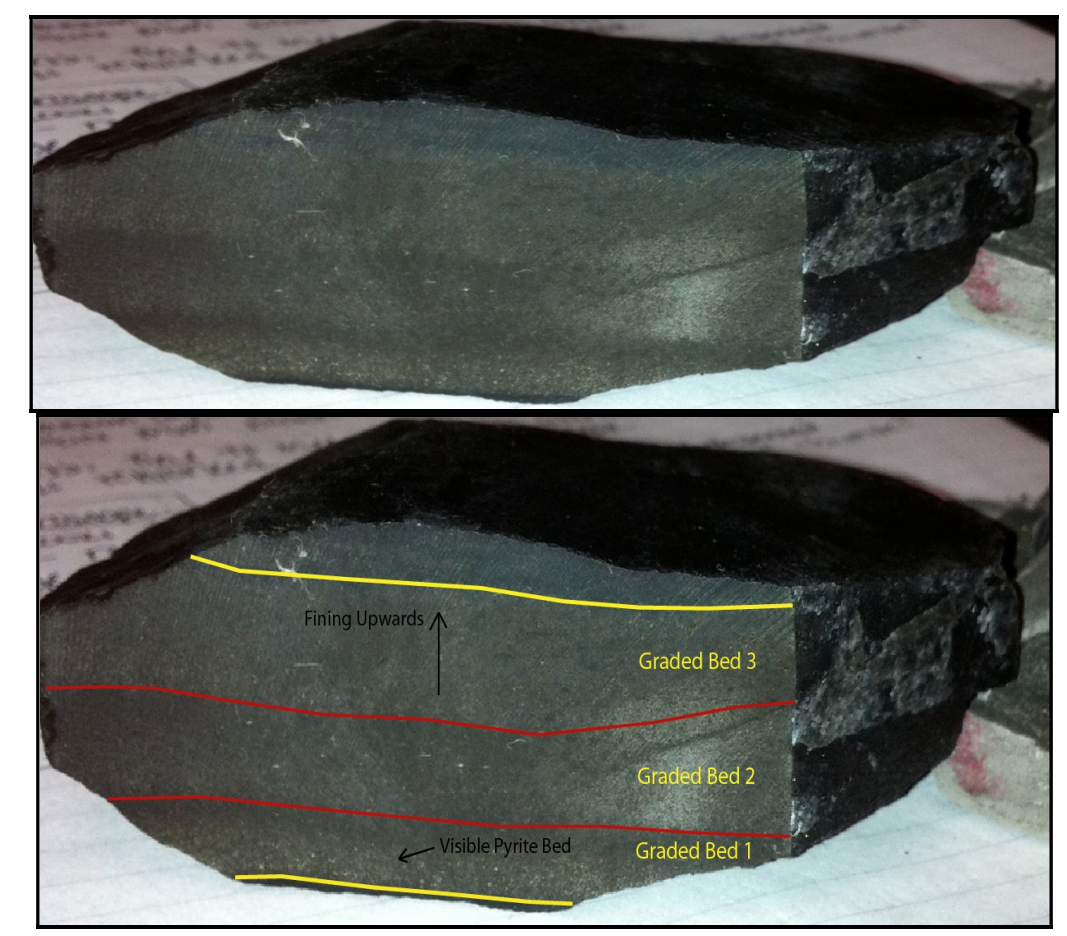

Figure 13. Winner 4-8 core Ash \#3. Displays three cyclic graded beds with pyrite, each fining upward. 
Another important diagnostic feature found in all ash layers in this study contains an increased concentration of white mica crystals, which implies a volcanic origin. White mica crystals may vary in size from very fine to very coarse sized crystals. Typically, coarser crystals will be found at the base of the ash layer up to $1 \mathrm{~mm}$ in length, while white mica will fine upward to the top of the ash horizon. White mica may not be visible to the naked eye, so inspection under a microscope or hand lens is necessary. Mica is found to either be completely distributed throughout the ash layer, or may only exist as a thin layer at the base of the ash. An example of an ash with large white mica crystals includes Figure 14 that displays Winner 4-8 core Ash \#4 at a depth of 8041.5 feet. Very coarse white mica crystals are found on both surfaces of the ash horizon that is located at the base of the ash. This particular ash has two graded bedding events also visible in Figure 14.

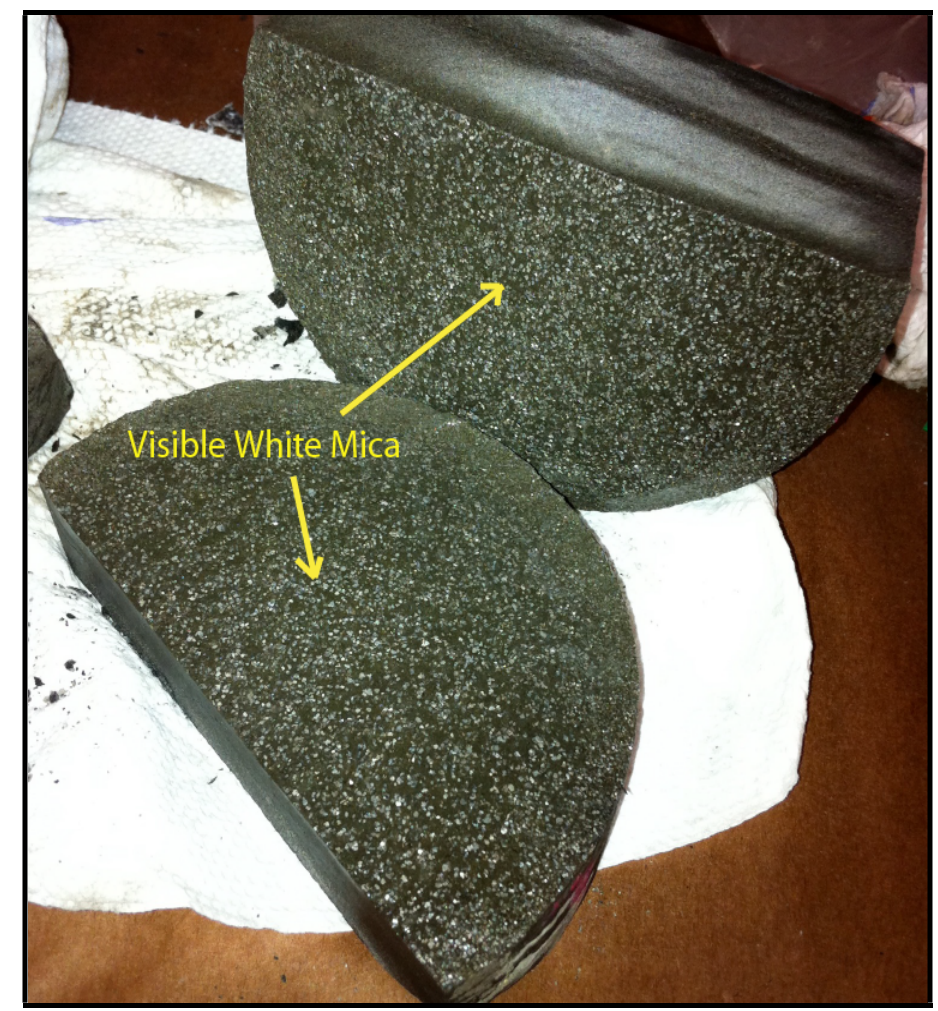

Figure 14. Winner 4-8 core Ash \#4. Displays very coarse white mica crystals on both surfaces of ash horizon at the base of the ash layer. 
Most ash layers described contain large concentrations of pyrite crystals. Pyrite is found to either be distributed throughout the entire ash layer, only at the base, accumulations in fractures in shale and ash layers, or completely absent. Pyrite crystals tend to be much smaller than white mica crystals in most core. Typically pyrite will be found in higher concentrations and with larger size crystals at the base of graded ash beds. Pyrite will fine upward due to graded bedding from very fine to medium pyrite crystals in size. Pyrite may not be visible to the naked eye, so inspection under a microscope or hand lens is necessary. An example of visible pyrite distributed at the base of a graded ash bed is found in Figure 15. Winner 4-8 core Ash \#1 layer at depth 8023.5 feet exhibits fine grained pyrite crystals at the base of the ash that has a contact line drawn in between the ash bed and shale. Pyrite may also be found as pyrite nodules on the edges or within the core.

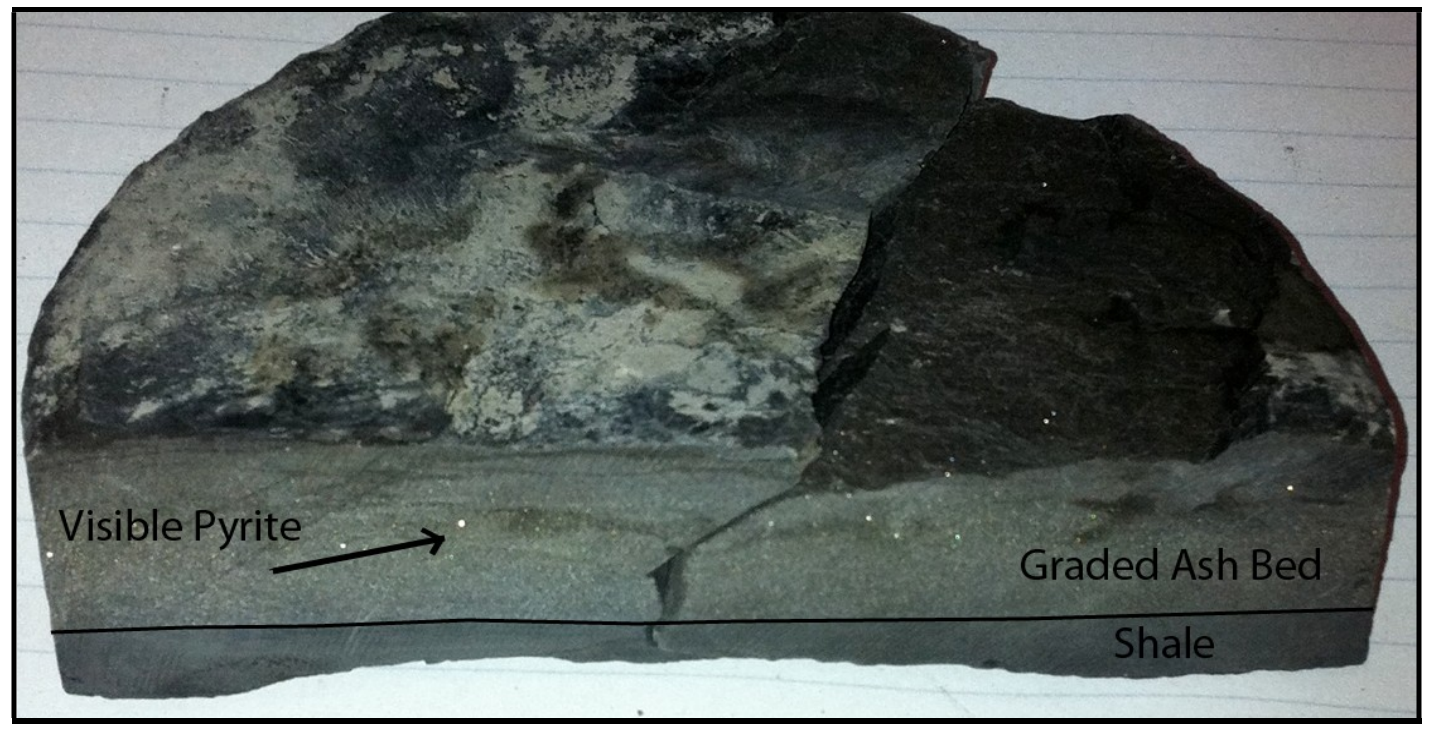

Figure 15. Winner 4-8 core Ash \#1. Displays fine grained pyrite crystals distributed throughout ash horizon. Abrupt contact at the base of the ash is visible.

Several other common features found on some ash layers include fossil hash, slickenlines, and calcite veins. Four cores including Coldstream 1MH Ash \#4, Coldstream 1MH Ash \#5, Armstrong \#1 Ash \#7, and Winner 4-8 Ash \#3 all contain micofossil hash. Fossils found 
in these four ashes include 2-3 mm brachiopods in length, up to $3 \mathrm{~mm}$ in length tentaculites, and up to $3 \mathrm{~mm}$ in length straight cephalopods. Microfossils are clearly visible under a microscope or hand lens. An example of a core that includes a layer of fossil hash can be seen in Figure 16.

Coldstream 1MH Ash \#4 displays graded bedding of white mica at the base of the ash layer.

Micofossils are found at the top of the ash layer and include fossils such as $3 \mathrm{~mm}$ tentaculites and $3 \mathrm{~mm}$ straight cephalopods.

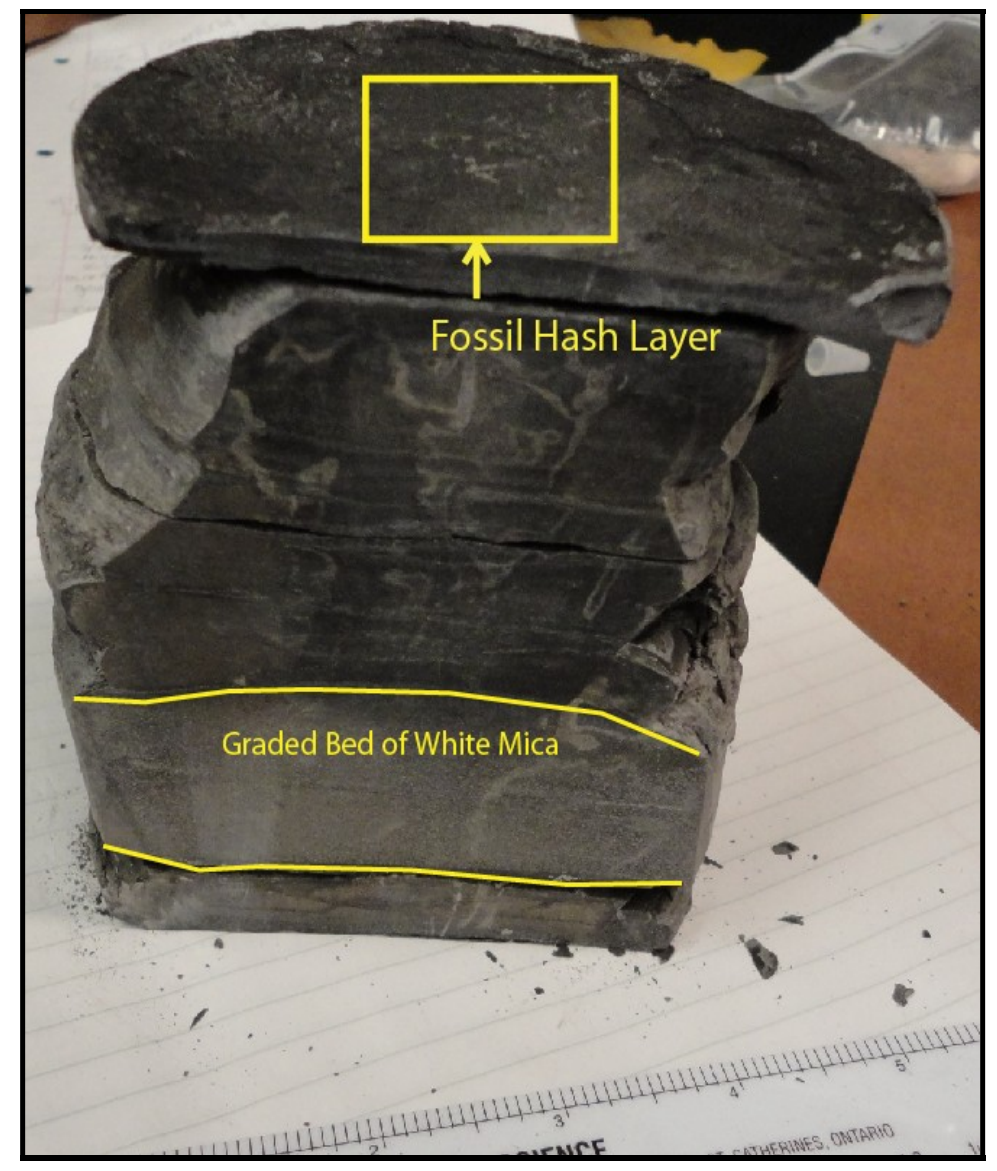

Figure 16. Coldstream 1MH core Ash \#4. Displays graded bed of white mica at the base of the ash. Fossil hash found at the top of the ash layer.

Fossils are extremely abundant and silver metallic in color. The micofossil hash layers found in these four cores may be attributed to the ash falling through the water column and destroying the 
sensitive environment these organisms were once living in, allowing them to fall through the water column as well.

Slickenlines and calcite veins within fractures are commonly found in the Marcellus

Shale and Onondaga Limestone described from all six cores. All surfaces of the ash layers were tested with HCL and the only reaction took place on both slickenlines and calcite veins.

Complete ash descriptions for every core can be found in Appendix I. 


\section{ZIRCON ANALYSIS}

The decay of the naturally occurring isotopes of Uranium will produce specific geochronometers. The decay of ${ }^{238} \mathrm{U}$ to ${ }^{206} \mathrm{~Pb}$ can be described as a function of time by the equation $\frac{206_{P b}}{238_{J}}=e^{\lambda t}-1$ (Faure, 1986). Using this equation, zircons that are Uranium-bearing minerals can yield concordant dates, which is the point at when two geochronometers agree with each other such as ${ }^{238} \mathrm{U} /{ }^{206} \mathrm{~Pb}$ and ${ }^{235} \mathrm{U} /{ }^{207} \mathrm{~Pb}$. Zircons that contain a very high ${ }^{238} \mathrm{U} /{ }^{204} \mathrm{~Pb}$ ratio can provide special geochronological opportunities that allow a Concordia diagram to be developed (Faure, 1986). The Concordia diagrams using zircons in this study plots ${ }^{207} \mathrm{~Pb} /{ }^{206} \mathrm{~Pb}$ vs. ${ }^{238} \mathrm{U} /{ }^{206} \mathrm{~Pb}$ ratios that are proportional to time. The concordia curve produced is the locus of points where the ${ }^{238} \mathrm{U} /{ }^{206} \mathrm{~Pb}$ ratio age equals the ${ }^{207} \mathrm{~Pb} /{ }^{206} \mathrm{~Pb}$ ratio age.

Concordia diagrams and weighted mean plots were made for all sixteen samples. Plot comparisons of ${ }^{207} \mathrm{~Pb} /{ }^{206} \mathrm{~Pb}$ vs. ${ }^{238} \mathrm{U} /{ }^{206} \mathrm{~Pb}$ ratios were made to test the concordance of individual zircon crystal ages per horizon. Figure 17 displays the isotopic ratios for 12 zircons from Ash \#5 of the Coldstream \#1 well. All square points in blue represent ages that are concordant and do not have large errors in age. Red circles represent ages that fall too far from the concordia line or are not correlative with the concordant points. Points that fall too far from the concordia line are considered discordant dates.

A weighted mean plot of individual zircons are also created for each ash horizon including all zircons from that ash. The weighted means plots are useful in displaying errors for each age and calculating the average means of overlap between zircons. The average age is then calculated based on the most coherent group of ages produced. Figure 18 displays Coldstream well \#1 Ash \#5 weighted means of 11 of the 12 zircons dated. One zircon was left out due to the

age being abnormally too high at $447.4 \pm 5.2 \mathrm{Ma}$ and having high ${ }^{204} \mathrm{~Pb}$, which is an indication of 
contamination by non radiogenic (common) $\mathrm{Pb}$. The most coherent group was produced from 8 ashes and calculated an age of $396.7 \pm 3.0 \mathrm{Ma}$ and is interpreted as the eruption age of the ash.

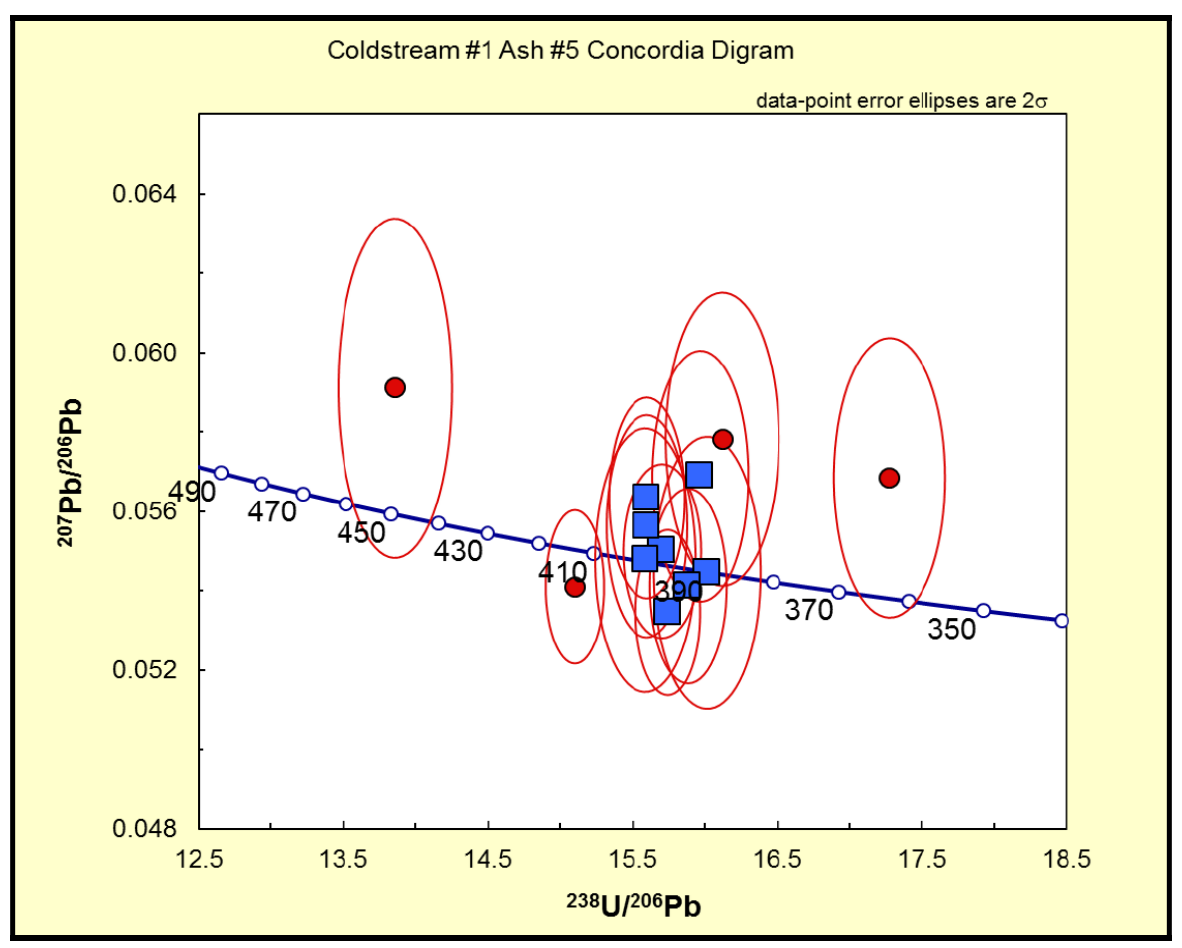

Figure 17. Isotopic ratios ${ }^{207} \mathrm{~Pb} /{ }^{206} \mathrm{~Pb}$ vs. ${ }^{238} \mathrm{U} /{ }^{206} \mathrm{~Pb}$ for 12 zircons from Ash \#5 of the Coldstream \#1 well. Blue square points represent concordant ages, while red circles represent disconcordant ages.

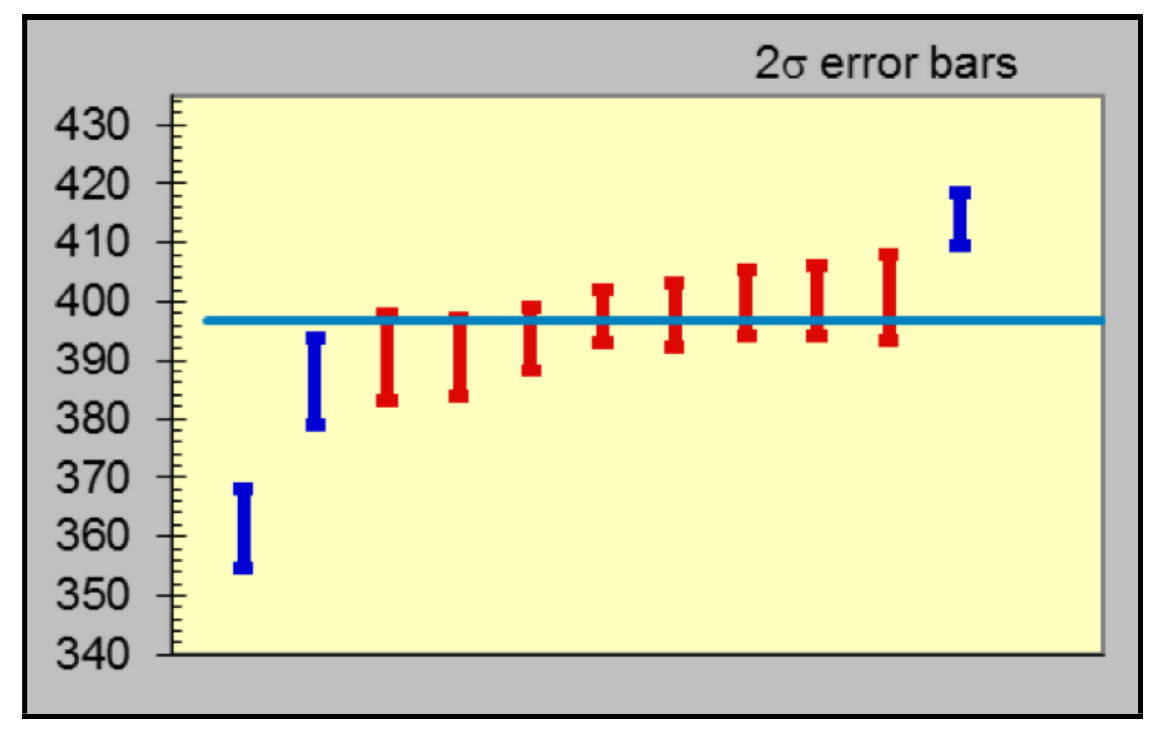

Figure 18. Weighted means plot of 11 zircons from Coldstream \#1 Ash \#5. The coherent group of 8 ashes produced an age of 396.7 \pm 3.0 Ma. Ages are calculated from ${ }^{238} \mathrm{U} /{ }^{206} \mathrm{~Pb}$ ages $(\mathrm{Ma})$. 
Another example of a calculated age completed by the SHRIMP RG includes Goff \#55 Ash \#2. Plot comparisons of ${ }^{207} \mathrm{~Pb} /{ }^{206} \mathrm{~Pb}$ vs. ${ }^{238} \mathrm{U} /{ }^{206} \mathrm{~Pb}$ ratios were made to test the concordance of individual zircon crystal ages per horizon. Figure 19 displays the isotopic ratios for 15 zircons from Ash \#2 of the Goff \#55 well. Points that fall too high or low around the concordia line will be eliminated due to lead loss or inheritance. In this example, a discordant point that falls above the concordia line at the age of $324.2 \pm 2.2 \mathrm{Ma}$ has a high uranium concentration of $499 \mathrm{U} \mathrm{ppm}$. Uranium decay process causes damage to the crystal lattice allowing lead to leach out easier. Lead loss will produce an underestimated age, or younger age, in comparison to the other zircons tested, in this case the age can be discarded.

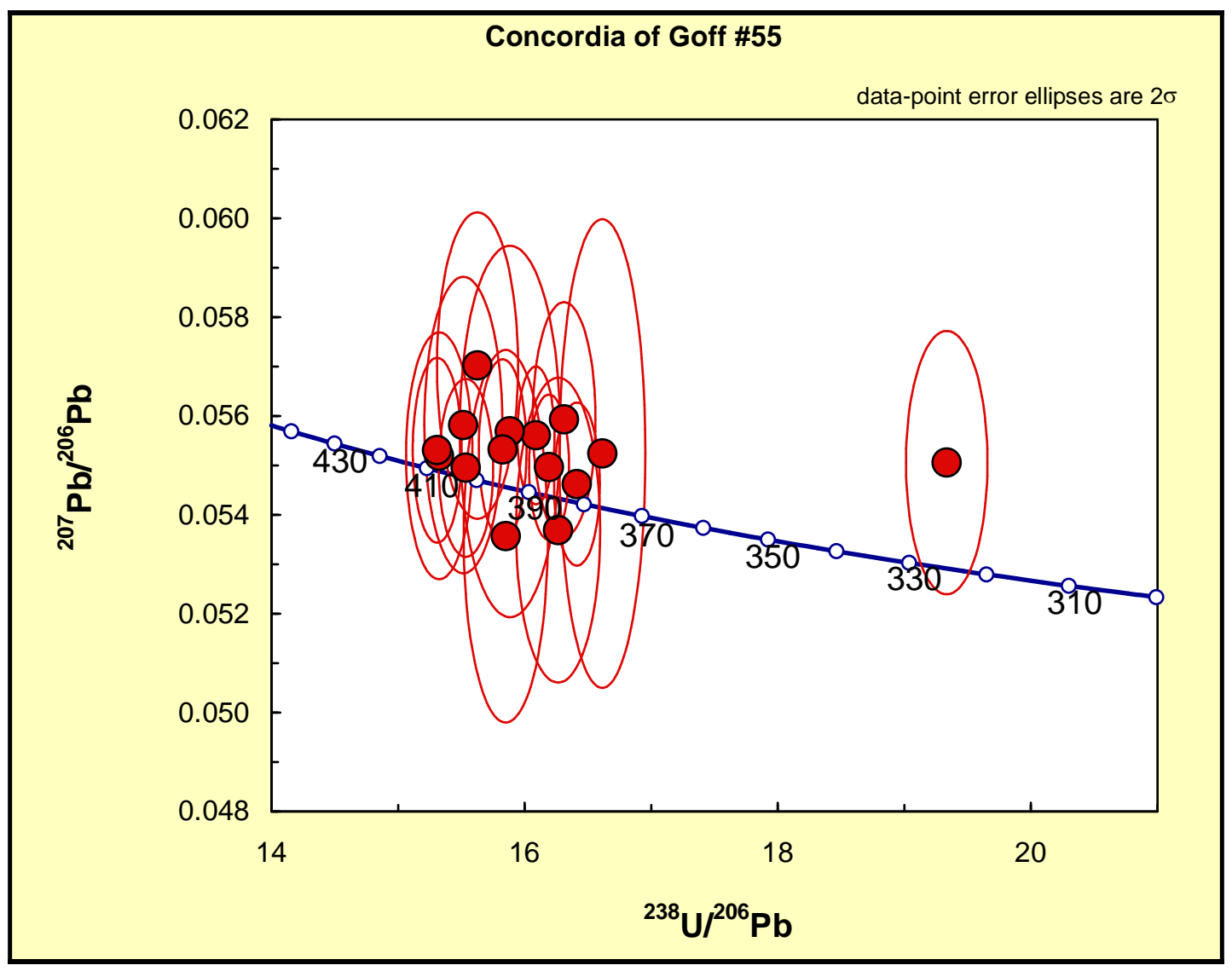

Figure 19. Concordia diagram displaying Goff \#55 well location, ash horizon two. Outlier age shown at 324.2 Ma. Error included as red ellipses. 
Figure 20 displays the actual zircon Grain \#1 that was dated pictured by Transmitted Light Microphotography and SEM-CL imaging. The Microphotography image captures locations on the zircon that may contain cracks or broken areas of the crystal. The SEM-CL does not capture this as well, but displays the location that the primary ion beam was placed when the analysis was being completed. These images help visualize physical features on the grains that should be avoided before dated, therefore reducing the risk of producing an unreliable age.
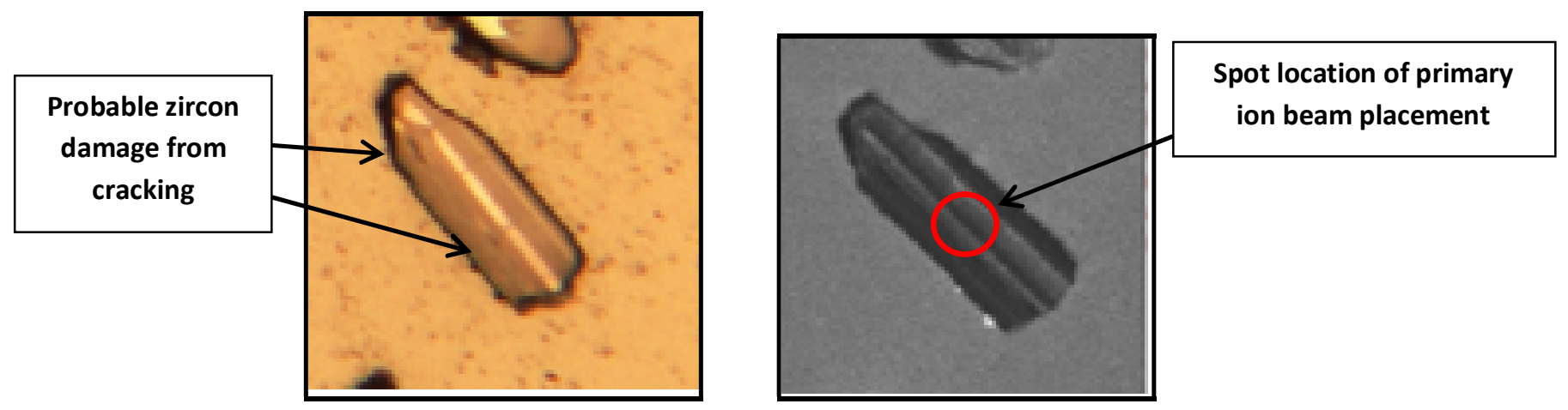

Figure 20. Goff \#55 Ash 2, Grain 1 dated shown in Transmitted Light Microphotography (Left) and SEM-CL (Right) displaying grain damage

With Grain 1 eliminated, the new Goff \#55 Ash \#2 concordia diagram shown in Figure 21 displays 14 zircon ages plotted over the concordia line with error included as red ellipses. Goff \#55 Ash \#2 does not display a single cluster of zircons that have similar ages. Most other ash horizon concordia plots produce an obvious group of ages that are concordant.

Due to the fact that an obvious cluster of zircon ages are not produced from the concordia diagram of Goff \#55 Ash \#2, another method of producing an accurate understanding of the ages must be produced. A weighted means diagram of Goff \#55 Ash \#2 in Figure 22 plots the 14 ages with error to depict whether there are similarities with any of the ages. 


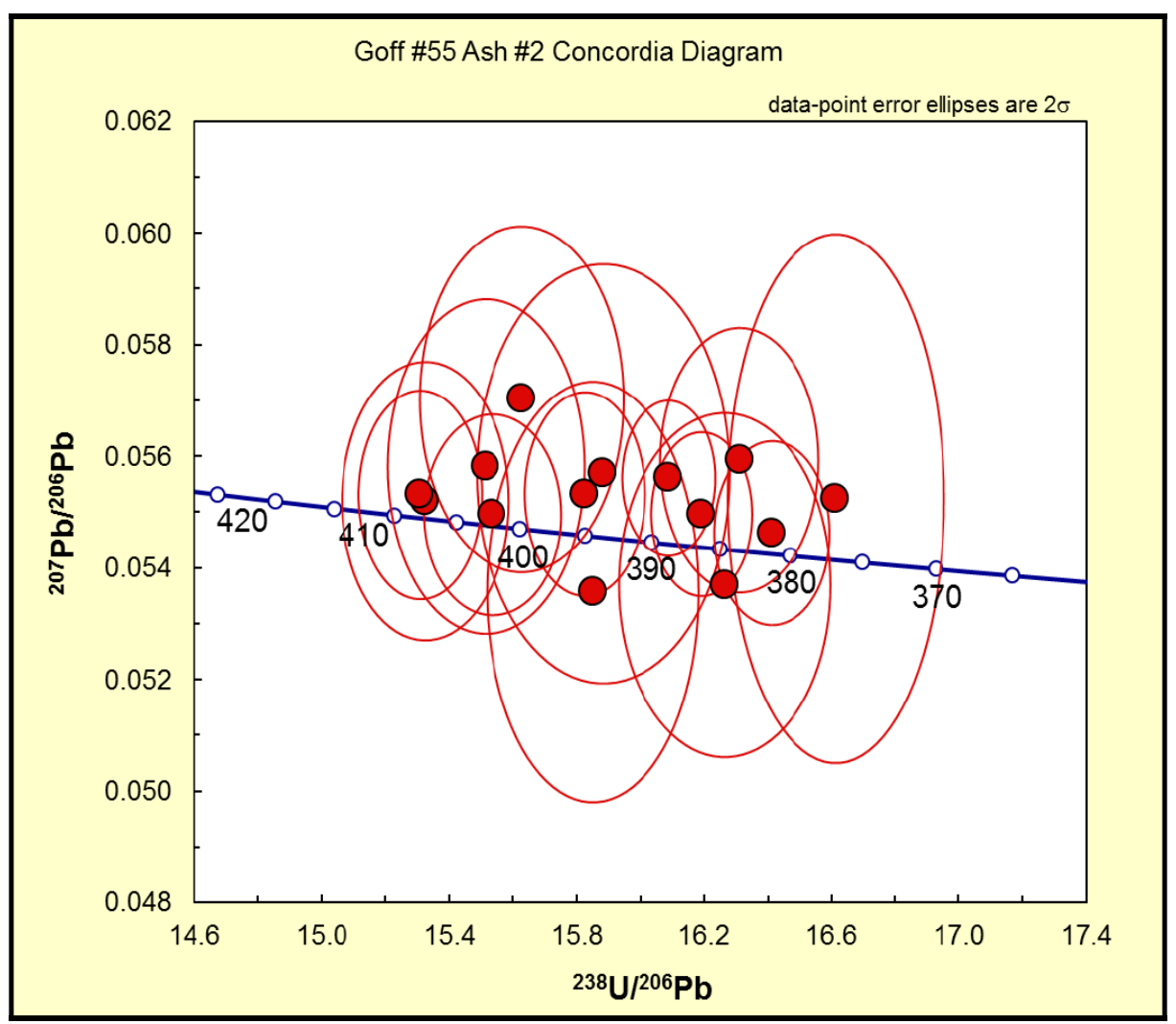

Figure 21. Goff \#55 Ash \#2 Concordia diagram with zircon outlier eliminated due to high Uranium concentrations.

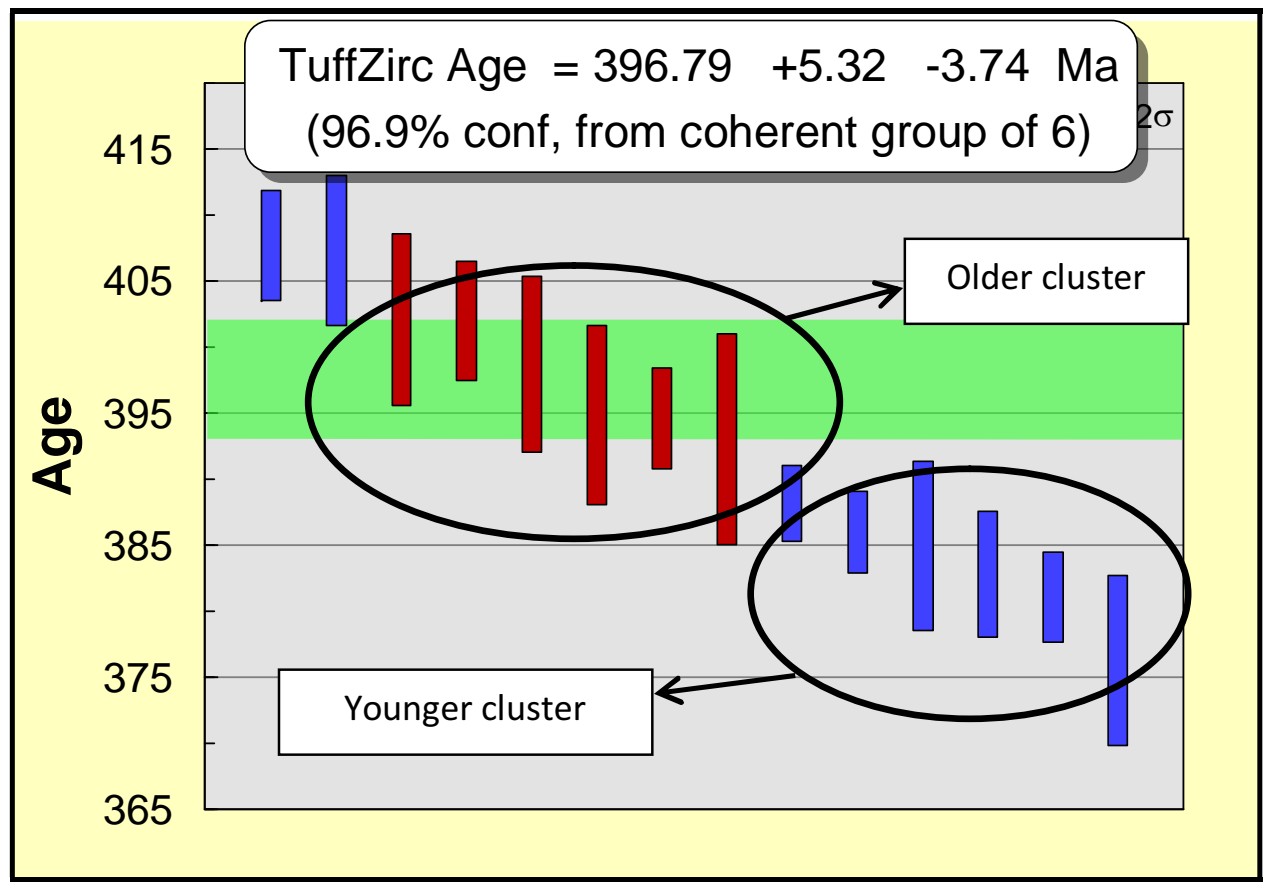

Figure 22. Average ${ }^{206} \mathrm{~Pb} /{ }^{238} \mathrm{U}$ age of 14 zircon crystals in Goff \#55 core, ash horizon two, with weighted means and error included. Older and younger clusters are labeled. 
The average age of $396.79 \pm 2.6 \mathrm{Ma}$ is calculated based on the most coherent group of ages. The coherent group does not appear to be the youngest cluster of ages, but several of the younger ages have high concentrations of uranium. The younger cluster should not be chosen as a reliable average age for this analysis due to lead loss occurring in several of the younger grains.

It must be noted that on one single ash horizon, zircon individual concordant ${ }^{206} \mathrm{~Pb} /{ }^{238} \mathrm{U}$ ages can span in age from 10-20 million years. As seen in all ash horizons dated, ages for one ash layer do not cluster within a small 1 million year window. A large range of 10-20 million year age differences in one horizon is interpreted to represent the longevity of the magmatic system. The youngest coherent group of zircon crystals per horizon represents the best estimate of age of eruption, which would correlate with the depositional age in the basin. Older zircons may be reworked from earlier crystallization events in the magma chamber or the walls of the volcano. Although in the last example the youngest cluster was not chosen, other examples provide evidence of correct age clusters that represent eruption ages.

Thirteen zircons were discovered in 7 different ashes to have inherited cores that were dated to be much older in age than the rest of the zircons. The ${ }^{206} \mathrm{~Pb} /{ }^{238} \mathrm{U}$ ages range from 1001.5 $\pm 6.6 \mathrm{Ma}-1517.2 \pm 22.9 \mathrm{Ma}$. The figure displaying the zircons per 7 ashes can be found in Appendix I. The average age of the thirteen zircons with inherited cores is 1131.2 Ma. Figure 23 displays the U-Pb Concordia for all the inherited cores. The oldest zircon of 1517.2 $\pm 22.9 \mathrm{Ma}$ should be eliminated due to very large error. The inherited ages correlate well with typical Grenville Orogeny ages. The Grenville deformation occurred with an arc-continent collision at 1.3-1.2 Ga and a continent-continent collision at 1.1-1.05 Ga. Due to the location of the Grenville terrane, the inherited zircons are interpreted to source from this orogeny and exist within the basement of the Acadian arc (Streepey, 2004). 


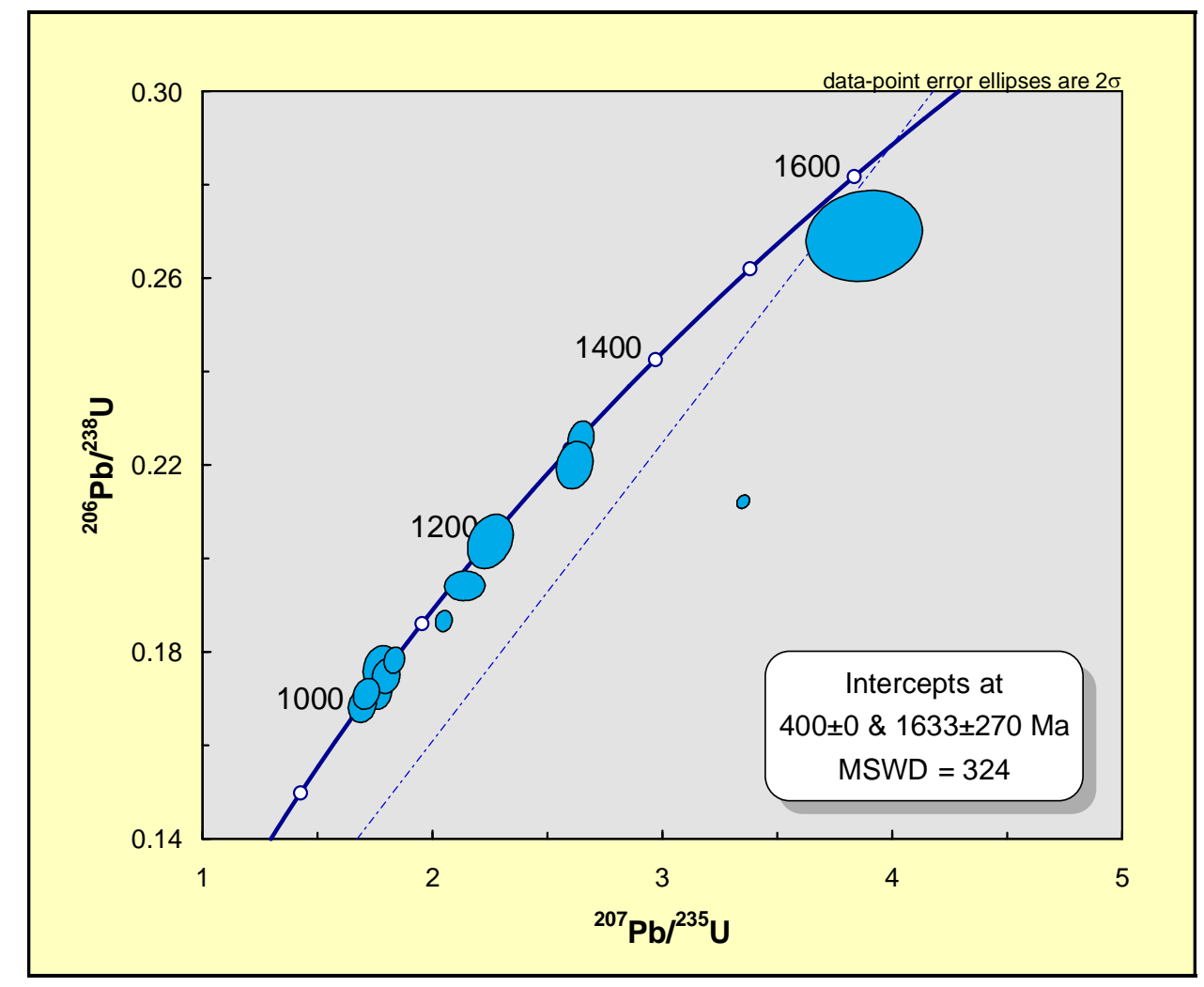

Figure 23. U-Pb Concordia plot of 13 inherited zircon ages from the Grenville basement rock of the Acadian arc.

Figure 24 is a table showing all ashes dated from six wells. The ash numbers are given with the depths in feet and thicknesses in inches of each ash horizon. The average ${ }^{206} \mathrm{~Pb} /{ }^{238} \mathrm{U}$ age in millions of years is given for each ash layer excluding the inherited ages. The thinnest ash is 0.24 inches, the thickest is 5.51 inches and the average thickness is 1.83 inches. Ages range from the youngest at $380.9 \pm 2.0 \mathrm{Ma}$ to the oldest $403.8 \pm 4.0 \mathrm{Ma}$. The oldest ash horizons tend to come from the western to northwestern portion of the cross section, while the youngest tend to come from the east to southeast areas of the well locations. 


\begin{tabular}{|c|c|c|c|c|}
\hline Well Name & $\begin{array}{c}\text { Ash Number } \\
\text { (core depth in ft) }\end{array}$ & $\begin{array}{c}\text { Ash Thickness } \\
\text { (inches) }\end{array}$ & $\begin{array}{c}\text { Weighted Mean } \\
{ }_{23} \mathbf{U} \text { / }{ }^{206} \mathbf{P b}\end{array}$ & MSWD \\
\hline EQT 511391 & $1(7114.0)$ & 0.47 & $403.8 \pm 4.0$ & 3.02 \\
Goff \#55 & $2(7117.05)$ & 2.36 & $402.1 \pm 1.8$ & 1.42 \\
& $1(7227.45)$ & 3.15 & $385.24 \pm 2.8$ & 1.28 \\
Armstrong \#1 & $2(7231.24)$ & 0.866 & $396.79 \pm 2.6$ & 1.59 \\
& $1(7755.27)$ & 0.24 & $384.2 \pm 2.4$ & 0.25 \\
St. Whipkey \#1 & $7(7780.46)$ & 0.48 & $380.9 \pm 2.0$ & 1.72 \\
& $2(7893.6)$ & 2.17 & $390.0 \pm 2.1$ & 0.1 \\
Coldstream \#1 & $4(7897.5)$ & 0.787 & $389.9 \pm 2.1$ & 105 \\
& $1(7165.7)$ & 1.18 & $400.74 \pm 2.2$ & 0.57 \\
& $2(7157.2)$ & 1.97 & $394.0 \pm 1.3$ & 1.2 \\
Winner 4-8 & $4(7162.4)$ & 3.94 & $398.5 \pm 1.3$ & 1.2 \\
& $5(7163.5)$ & 0.98 & $396.7 \pm 2.0$ & 1.7 \\
& $1(8023.5)$ & 0.88 & $383.6 \pm 1.4$ & 0.74 \\
& $2(8032.6)$ & 2.76 & $391.1 \pm 1.5$ & 1.59 \\
& $3(8035.4)$ & 1.57 & $391.0 \pm 3.1$ & 5.24 \\
\hline
\end{tabular}

Figure 24. All wells showing ash numbers and depths. Ash thickness in inches included. Average ${ }^{206} \mathrm{~Pb} /{ }^{238} \mathrm{U}$ age in millions of years for each ash horizon and MSWD included.

Compiling all of the ages from every zircon dated using the SHRIMP RG method will

produce a binned frequency diagram. Binned frequency diagrams are a common method for displaying age data. Modes, ranges and proportions can be related to timing, duration and relative significance of geologic events, in this case eruption ages (Fedo, Sircombe, Rainbird, 2003). The combination of a binned frequency diagram and a probability density distribution is shown in Figure 25. Using the probability density distribution will eliminate problems that arise from using just a histogram. Errors in the age data are included and produce a probability distribution of the entire sample that may vary with each individual age (Fedo, Sircombe, and Rainbird, 2003). Figure 25 contains all of the zircons dated but removes outliers below $370 \mathrm{Ma}$ and above $425 \mathrm{Ma}$. Each bin represents one million years and the number of zircon ages that fit within that bin. Major peaks are found at 384.7, 390.0, and 394.95 Ma. Minor peaks are found at 383.4, 399.0, 402.85, and 408.0 Ma. 


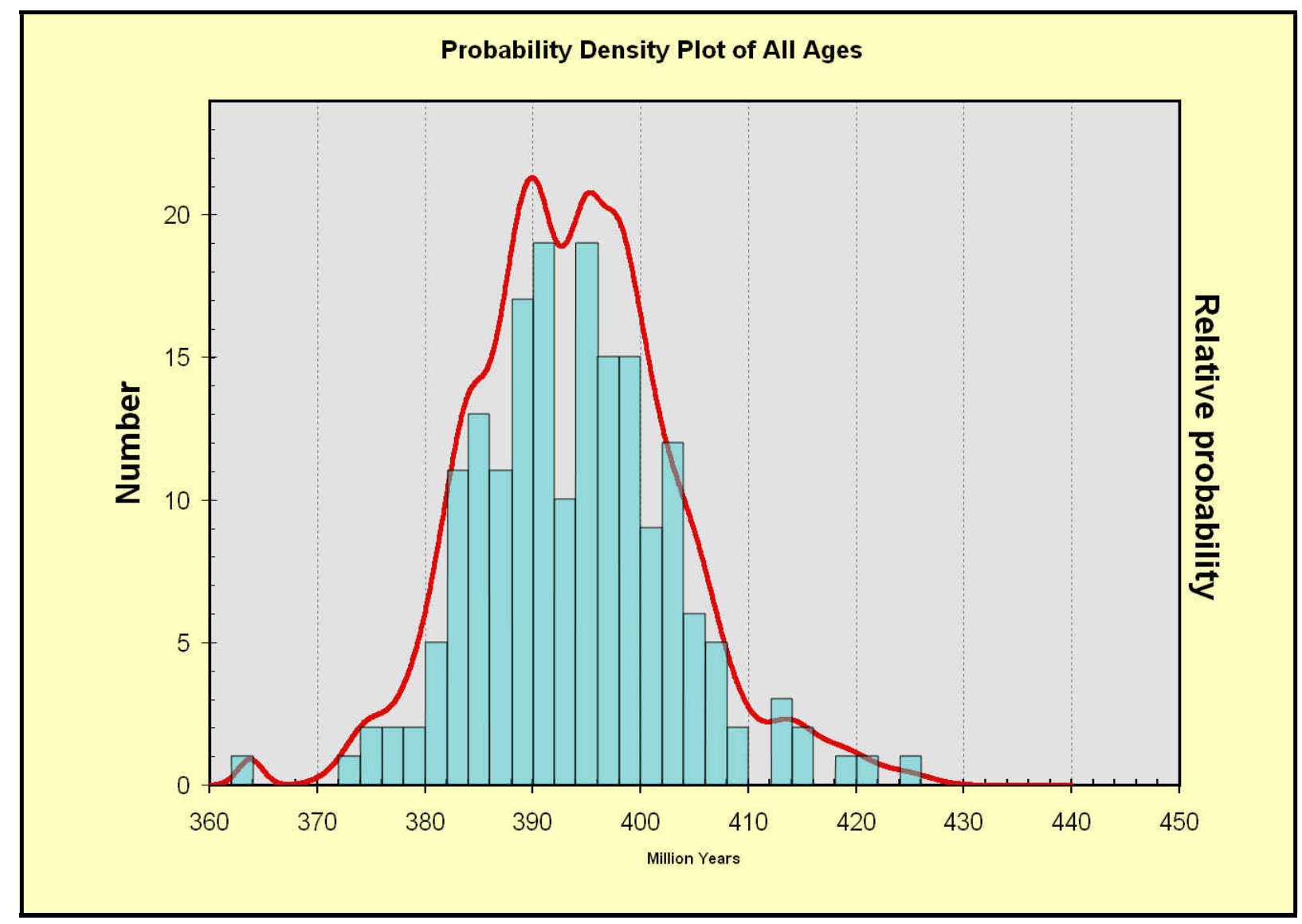

Figure 25. Probability density plot of all zircons dated removing outliers below $370 \mathrm{Ma}$ and above 425 Ma. Major peaks are found at 384.7, 390.0, and 394.95 Ma. Minor peaks are found at 383.4, 399.0, 402.85, and 408.0 Ma.

Placing the corresponding ${ }^{206} \mathrm{~Pb} /{ }^{238} \mathrm{U}$ age to the appropriate ash layer on the cross section in Figure 26 helps visualize the time duration between ashes. The uppermost and lowermost ashes are displayed for each individual well. Most wells display ashes that are younger at stratigraphically higher depths, which is the expected result. Two stratigraphically higher ash layers have older ages than deeper ashes, which presents a problem with the analysis. For example, the Armstrong \#1 well has two ash layers that were dated, Ash 1 at 7755.27 feet and Ash 2 at 7780.46 feet, with ages of 384.2 $\pm 2.4 \mathrm{Ma}$ and 380.9 $\pm 2.0 \mathrm{Ma}$. The shallower Ash 1 is 4 million years older than Ash 2, and the ages do not overlap even with a \pm 2.4 million year error. Ashes that are shallower should represent ages that are younger, which conflicts with the given 
data in the Armstrong \#1 well affecting the interpretation of the eruption age of ashes. Wells such as EQT 511391 and St. Whipkey \#1 also have shallow ashes with older ages, but the age errors fall within each other allowing these ages to be statistically equivalent. 


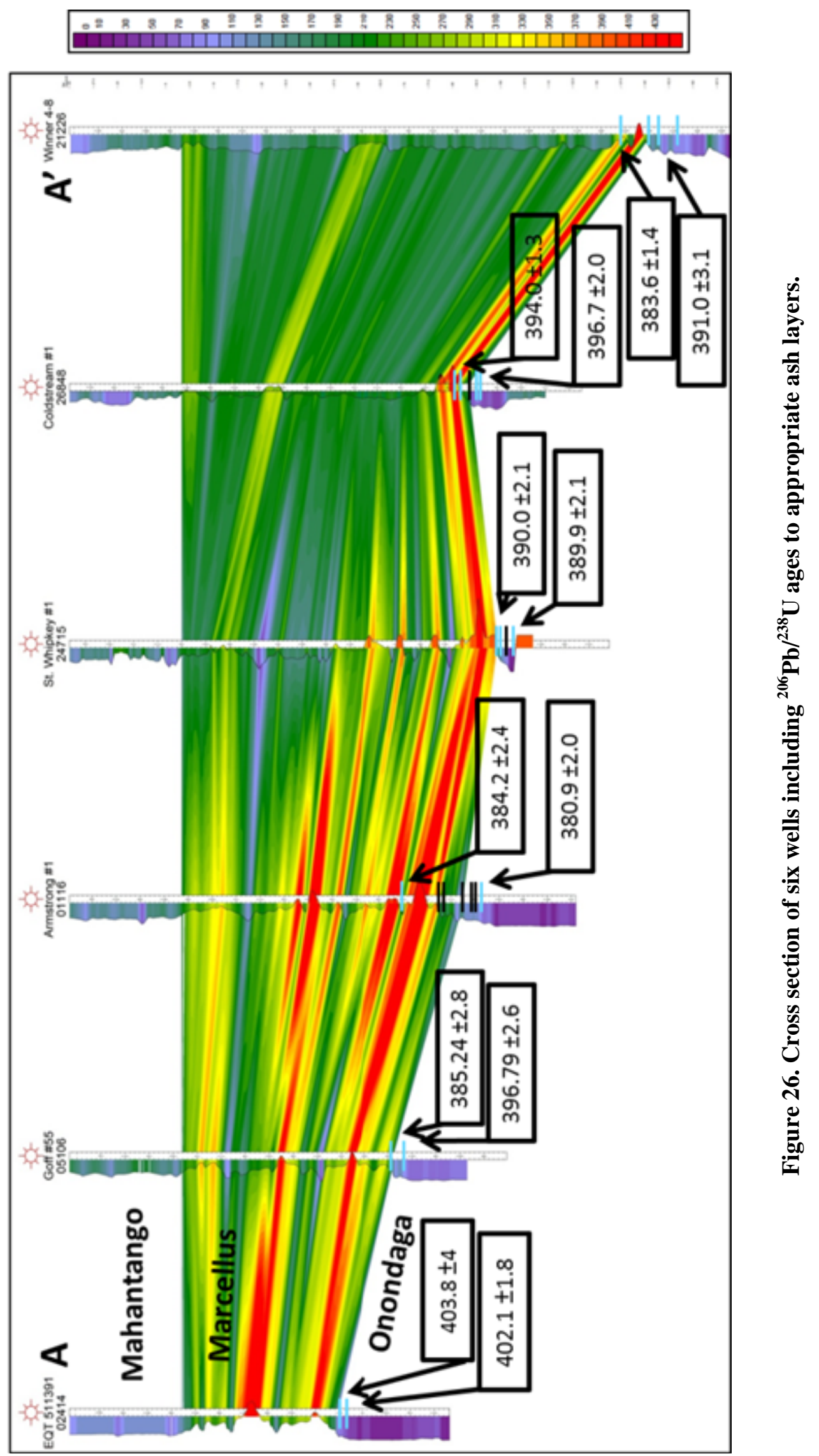


Despite problematic age data for EQT 511391 and Armstrong \#1 wells, estimations of sedimentation rates can be inferred from the uppermost and lowermost ashes of each well. Compacted and decompacted sedimentation rates were calculated using two equations.

Compacted sedimentation rates are calculated using the equation:

$$
\text { Sedimentation rate }=\frac{\text { thickness }}{\text { age }}
$$

Decompacted sedimentation rates are calculated using the equation to solve for initial thickness which can then be used in the original compacted sedimentation rate equation:

$$
\frac{d_{\text {pd }}}{d_{\text {initial }}}=\frac{1-\emptyset_{\text {initial }}}{1-\emptyset_{\text {pd }}}
$$

$\mathrm{dpd}=$ Present day thickness

dinitial $=$ Initial thickness

$\varnothing \mathrm{pd}=$ Present day porosity

øinitial $=$ Initial porosity before burial $=70 \%($ Lash Field Trip Guide, 2008)

The $\mathrm{d}_{\text {initial }}=$ Initial thickness is then solved for and placed into the compaction equation to solve for the accurate decompacted sedimentation rates in ranges. Table 1 displays the compacted sedimentation rates for all six wells, the average sedimentation rates of the compacted rates, the decompacted sedimentation rates, and the average sedimentation rates of the decompacted rates. Compacted sedimentation rates for all wells are smaller than decompacted sedimentation rates. Average sedimentation rates of compacted sediment not including errors range from $0.33 \mathrm{ft} / \mathrm{my}$ to $7.6 \mathrm{ft} / \mathrm{my}$. Average sedimentation rates of decompacted sediment range from $0.98 \mathrm{ft} / \mathrm{my}$ to $21.7 \mathrm{ft} / \mathrm{my}$. Sedimentation rates whether compacted or decompacted varied throughout the Appalachian basin. 


\begin{tabular}{|c|c|c|c|c|}
\hline Well Name & $\begin{array}{c}\text { Compacted } \\
\text { Sedimentation } \\
\text { Rates }\end{array}$ & $\begin{array}{c}\text { Average Sed } \\
\text { Rates not } \\
\text { including } \\
\text { errors }\end{array}$ & $\begin{array}{c}\text { Decompacted } \\
\text { Sedimentation Rates }\end{array}$ & $\begin{array}{c}\text { Average Sed } \\
\text { Rates not } \\
\text { including } \\
\text { errors }\end{array}$ \\
\hline $\begin{array}{c}\text { EQT 511391 } \\
\text { (Ash 1 to 2) }\end{array}$ & $\begin{array}{c}0.29 \mathrm{ft} / \mathrm{my} \text { to } 4.3 \\
\mathrm{ft} / \mathrm{my}\end{array}$ & $1.3 \mathrm{ft} / \mathrm{my}$ & $0.84 \mathrm{ft} / \mathrm{my}$ to $3.7 \mathrm{ft} / \mathrm{my}$ & $1.53 \mathrm{ft} / \mathrm{my}$ \\
\hline $\begin{array}{c}\text { Goff \#55 } \\
\text { (Ash 1 to 2) }\end{array}$ & $\begin{array}{c}0.19 \mathrm{ft} / \mathrm{my} \text { to } 0.62 \\
\mathrm{ft} / \mathrm{my}\end{array}$ & $0.33 \mathrm{ft} / \mathrm{my}$ & $0.57 \mathrm{ft} / \mathrm{my}$ to $1.8 \mathrm{ft} / \mathrm{my}$ & $0.98 \mathrm{ft} / \mathrm{my}$ \\
\hline $\begin{array}{c}\text { Armstrong \#1 } \\
\text { (Ash 1 to 7) }\end{array}$ & $\begin{array}{c}3.3 \mathrm{ft} / \mathrm{my} \text { to } 22.9 \\
\mathrm{ft} / \mathrm{my}\end{array}$ & $7.6 \mathrm{ft} / \mathrm{my}$ & $9.3 \mathrm{ft} / \mathrm{my}$ to $65.1 \mathrm{ft} / \mathrm{my}$ & $21.7 \mathrm{ft} / \mathrm{my}$ \\
\hline $\begin{array}{c}\text { St. Whipkey \#1 } \\
\text { (Ash 2-4) }\end{array}$ & $\begin{array}{c}0.95 \mathrm{ft} / \mathrm{my} \text { to } 39 \\
\mathrm{ft} / \mathrm{my}\end{array}$ & $2.0 \mathrm{ft} / \mathrm{my}$ & $2.7 \mathrm{ft} / \mathrm{my}$ to $116.9 \mathrm{ft} / \mathrm{my}$ & $2.9 \mathrm{ft} / \mathrm{my}$ \\
\hline $\begin{array}{c}\text { Coldstream \#1 } \\
\text { (Ash 2 to 4) }\end{array}$ & $\begin{array}{c}0.73 \mathrm{ft} / \mathrm{my} \text { to } 2.74 \\
\mathrm{ft} / \mathrm{my}\end{array}$ & $1.2 \mathrm{ft} / \mathrm{my}$ & $2.2 \mathrm{ft} / \mathrm{my}$ to $8.2 \mathrm{ft} / \mathrm{my}$ & $3.5 \mathrm{ft} / \mathrm{my}$ \\
\hline $\begin{array}{c}\text { Winner 4-8 } \\
\text { (Ash 1 to 4) }\end{array}$ & $\begin{array}{c}0.9 \mathrm{ft} / \mathrm{my} \text { to } 1.98 \\
\mathrm{ft} / \mathrm{my}\end{array}$ & $1.2 \mathrm{ft} / \mathrm{my}$ & $6.8 \mathrm{ft} / \mathrm{my}$ to $53.7 \mathrm{ft} / \mathrm{my}$ & $10.8 \mathrm{ft} / \mathrm{my}$ \\
\hline
\end{tabular}

Table 1. Compacted and decompacted sedimentation rates for all six wells including the average sedimentation rates without errors.

The sedimentation rates found in this study can be related to several other black shale sedimentation rate studies. A study completed in Blake Nose of the Atlantic Ocean off the east coast of Florida (Barker, 2001). Figure 27 displays five sampling locations completed in Blake Nose. The sedimentation rates range from $19.7 \mathrm{ft} / \mathrm{my}-141 \mathrm{ft} / \mathrm{my}$, which are higher than the values found in the Marcellus Shale. Paleo-water depth and the location of the black shale accumulation within a basin must be taken into consideration when observing sedimentation rates. Shown in Table 2, is the location of each sample in reference to the paleo shelf break, paleo-water depth, and measured TOC. 


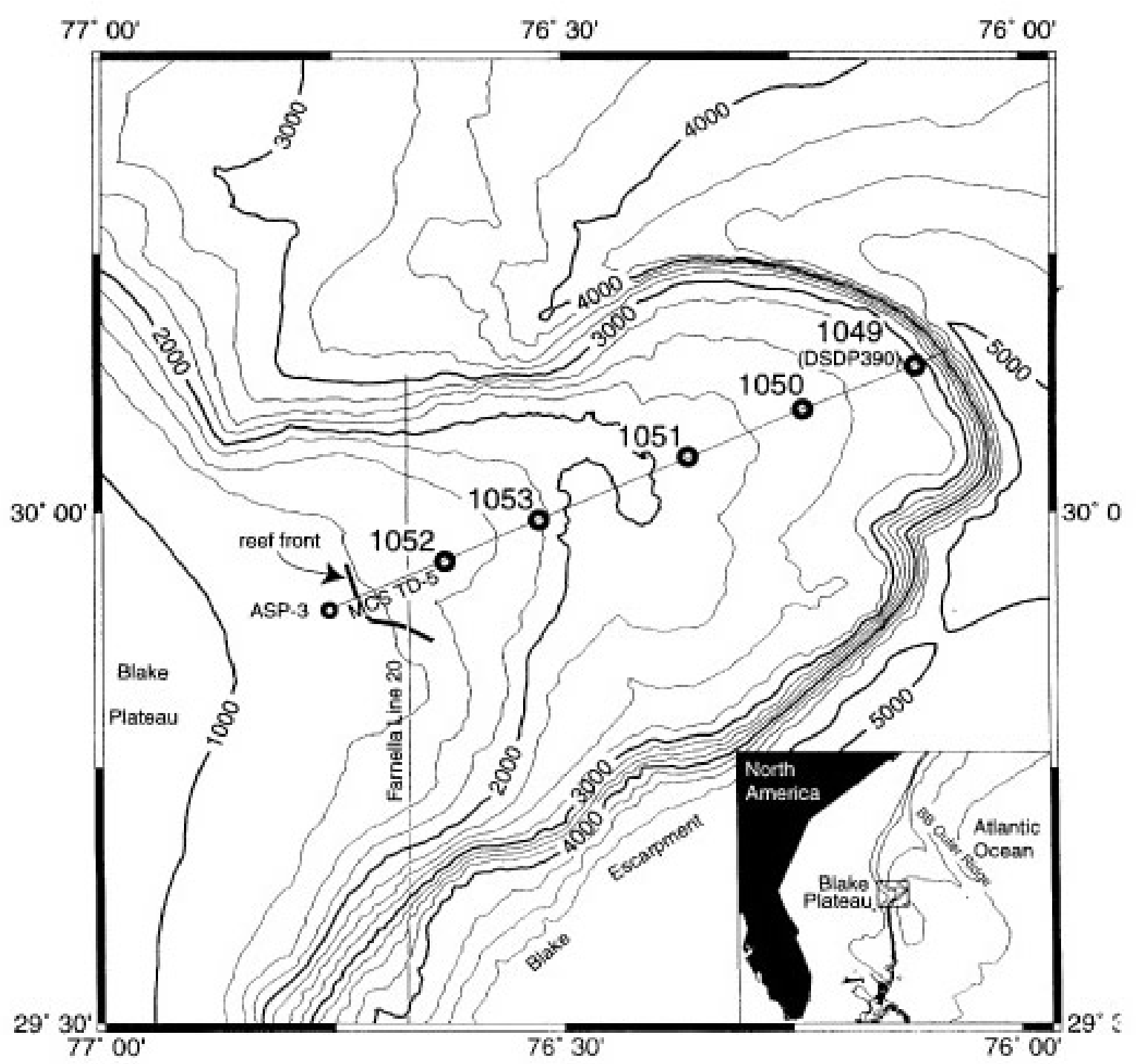

Figure 27. Location of Blake Nose of the Atlantic black shale sampling locations. (taken from Barker, 2001).

\begin{tabular}{|c|c|c|c|c|}
\hline Location & $\begin{array}{c}\text { Distance to shelf } \\
\text { break }\end{array}$ & Paleo-water depth & Sedimentation Rates & $\begin{array}{c}\text { Mean TOC } \\
(\mathbf{w t} \%)\end{array}$ \\
\hline $1052 \mathrm{E}$ & $20 \mathrm{~km}$ & $100-200 \mathrm{~m}$ & $43 \mathrm{~m} / \mathrm{Ma}=141 \mathrm{ft} / \mathrm{Ma}$ & 0.6 \\
\hline $1050 \mathrm{C}$ & $50 \mathrm{~km}$ & $\sim 1500 \mathrm{~m}$ & $17 \mathrm{~m} / \mathrm{Ma}=55.8 \mathrm{ft} / \mathrm{Ma}$ & 0.7 \\
\hline $1049 \mathrm{~A}$ & $60 \mathrm{~km}$ & $1500 \mathrm{~m}$ & $6 \mathrm{~m} / \mathrm{Ma}=19.7 \mathrm{ft} / \mathrm{Ma}$ & 4.6 \\
\hline
\end{tabular}

Table 2. Blake Nose of the Atlantic Ocean black shale sedimentation rates study (taken from Barker, 2001). 
The study shows that at increasing water depths and distance from the shelf edge, sedimentation rates will decrease and mean Total Organic Carbon (TOC) will increase. There is an inverse relationship between TOC and sedimentation rates of black shales (Ibach, 1980). As sedimentation rates increase, TOC will decrease due to the introduction of oxygen, aerobic microbial degradation of organic matter and the dilution effect of the clastic material. Low sedimentation rates generate higher TOC, which then allows an increase in hydrocarbon generation. This is valuable information for researchers trying to locate hydrocarbons for drilling.

A study completed by the Deep Sea Drilling Project provided average sedimentation rates of black shales around the world to be between $4 \mathrm{~m} / \mathrm{Ma}-230 \mathrm{~m} / \mathrm{Ma}(13 \mathrm{ft} / \mathrm{Ma}-754 \mathrm{ft} / \mathrm{Ma})$ (Ibach, 1980). Although these sedimentation rates seem high, they are taken from a variety of depositional settings including inland sea, marginal back-arc basin, active and passive continental margins, and deep ocean basin environments. To place the sedimentation rates of the Marcellus into perspective to other basins, the depositional environment must be compared. Shallow waters close to a sediment source will provide high sedimentation rates and low TOC values. Deep waters with little sediment influx will produce low sedimentation rates and high TOC values. With the data from this study, the Marcellus black shale with sedimentation rates between $1 \mathrm{ft} / \mathrm{my}$ to $22 \mathrm{ft} / \mathrm{my}$ would then be placed in a deep water environment with little sediment accumulation allowing the preservation of the fine grained ash beds.

Figure 28 compares the sedimentation rates in $\mathrm{m} / \mathrm{Ma}$ and TOC (wt $\%$ ) values of the black shale measured in the Deep Sea Drilling Project versus the Marcellus Shale values. The black shales of the Blake Nose project produce a trend visible from three data points. As sedimentation rates decrease, TOC (wt $\%$ ) will increase. The Marcellus point was plotted using an average 
sedimentation rate of $3 \mathrm{~m} / \mathrm{Ma}$ and average $8 \mathrm{wt} \%$ TOC. The Marcellus point plots on trend with the three black shale points from the Deep Sea Drilling Project. Figure 28 implies that the Marcellus sedimentation rates and TOC values fall within an acceptable and realistic range of values when compared to other locations in other basins.

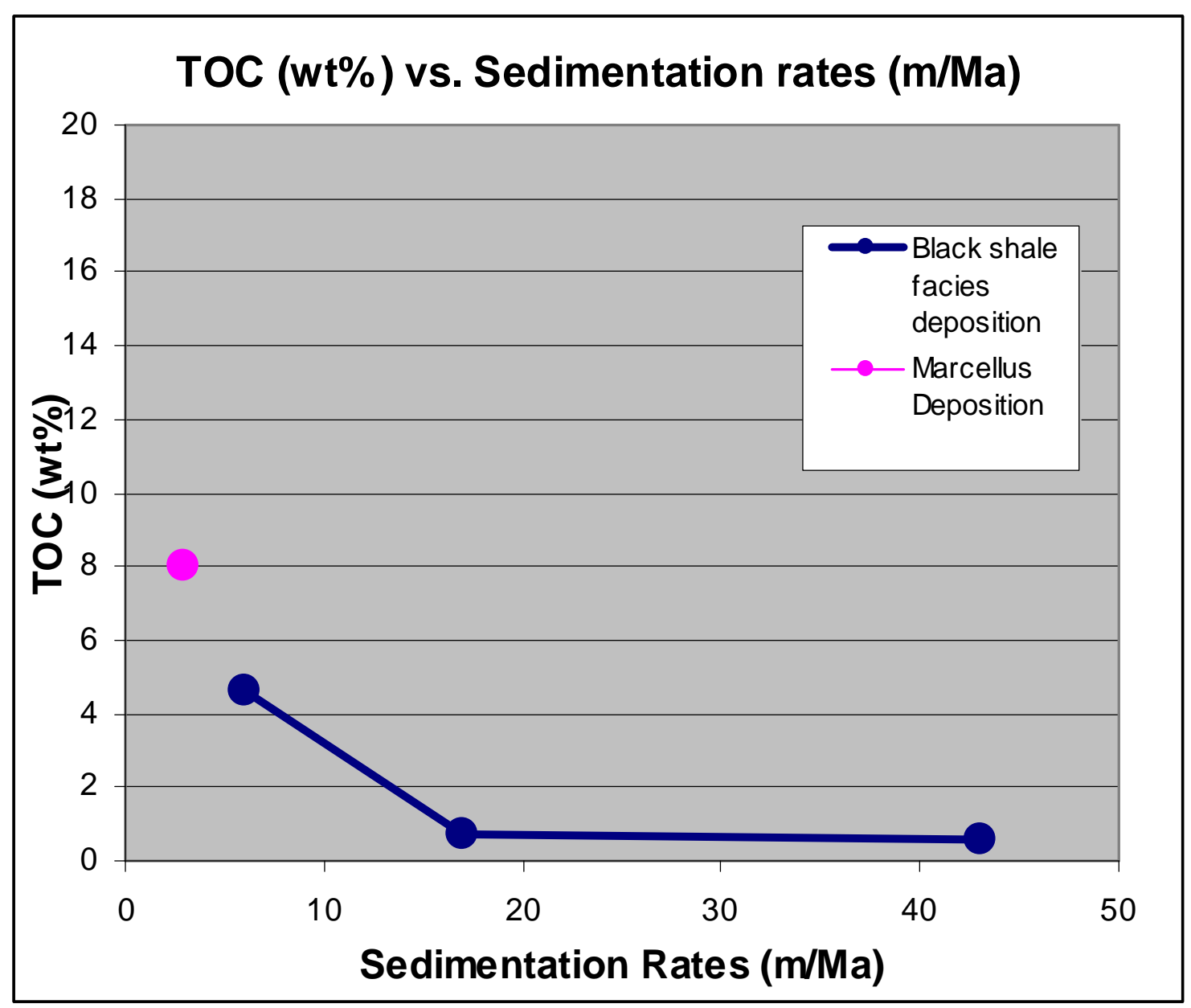

Figure 28. TOC (wt\%) vs. sedimentation rates in $\mathrm{m} / \mathrm{Ma}$. Blue line represents the black shale deposits measured in Blake Nose. The pink point represents the Marcellus TOC (wt\%) and sedimentation rates calculated in this study. 


\section{RARE EARTH ELEMENTS}

\section{Trace Elements Plots}

Zircon is a common accessory mineral in majority of igneous rocks with $\mathrm{Zr}$ as a very important structural component. Zircons are a host for significant fractions of whole-rock abundances of $\mathrm{U}, \mathrm{Th}, \mathrm{Hf}$, and the Rare earth elements. In this study, the rare earth elements and elements such as $\mathrm{U}, \mathrm{Th}, \mathrm{Pb}$, and $\mathrm{Hf}$ were measured for geochemical purposes in addition to the age determination. Rare earth elements (REE) can also provide insight to crustal evolution and petrogenesis of the source rock that provided these zircons into the ash horizons found in the Marcellus Shale and Onondaga Limestone. Trace element plots and REE concentrations for each zircon dated with the SHRIMP RG are recorded in this study.

All of the zircons were plotted comparing $\mathrm{U} / \mathrm{Yb}$ ratio versus $\mathrm{Hf}(\mathrm{ppm})$ to display where the zircons fall within the boundaries of the mid-ocean ridge basalt field (MORB Field). Figure 29 plots all zircons above the MORB Field and mostly within the Limit of Peninsular Range Plutons of northern Baja California, which is an example of a subduction related continental margin magmatic arc. Several of the zircons fall out of the boundary of the Limit of Peninsular Range Plutons of Baja California, but do fall above the MORB Field, allowing the assumption that the zircons are not from an oceanic setting. If the zircons plot within the Peninsular Range Plutons, this implies the zircons were formed as a body of intrusive igneous rock. The most common types of plutons are granite, granodiorite, tonalite, monzonite, and quartz diorite.

This plot can be simplified and compared to a study that attempts to distinguish detrital zircon provenances. Grimes et al., 2007 uses geochemical discriminant diagrams for zircons to differentiate the oceanic field from continental field shown in Figure 30. The line represents the upper limit for zircons that are unambiguously ocean crustal in origin, which is comparable to the MORB Field line drawn in Figure 29. This study incorporates data from ocean crust zircons, 
Talkeetna Island Arc, and zircons from granitoid intrusions from northern Chile and eastern Australia, kimberlites, and oceanic crust (Grimes et al, 2007). A plot was constructed using zircons from the Appalachian Basin in this study to compare to Grimes et al., 2007. Using the continental field outlined by Grimes et al., 2007, Figure 31 displays all zircons falling within the continental granitoid field. The equivalent of this field would be the Limit of Peninsular Range Plutons of Baja California in Figure 29.

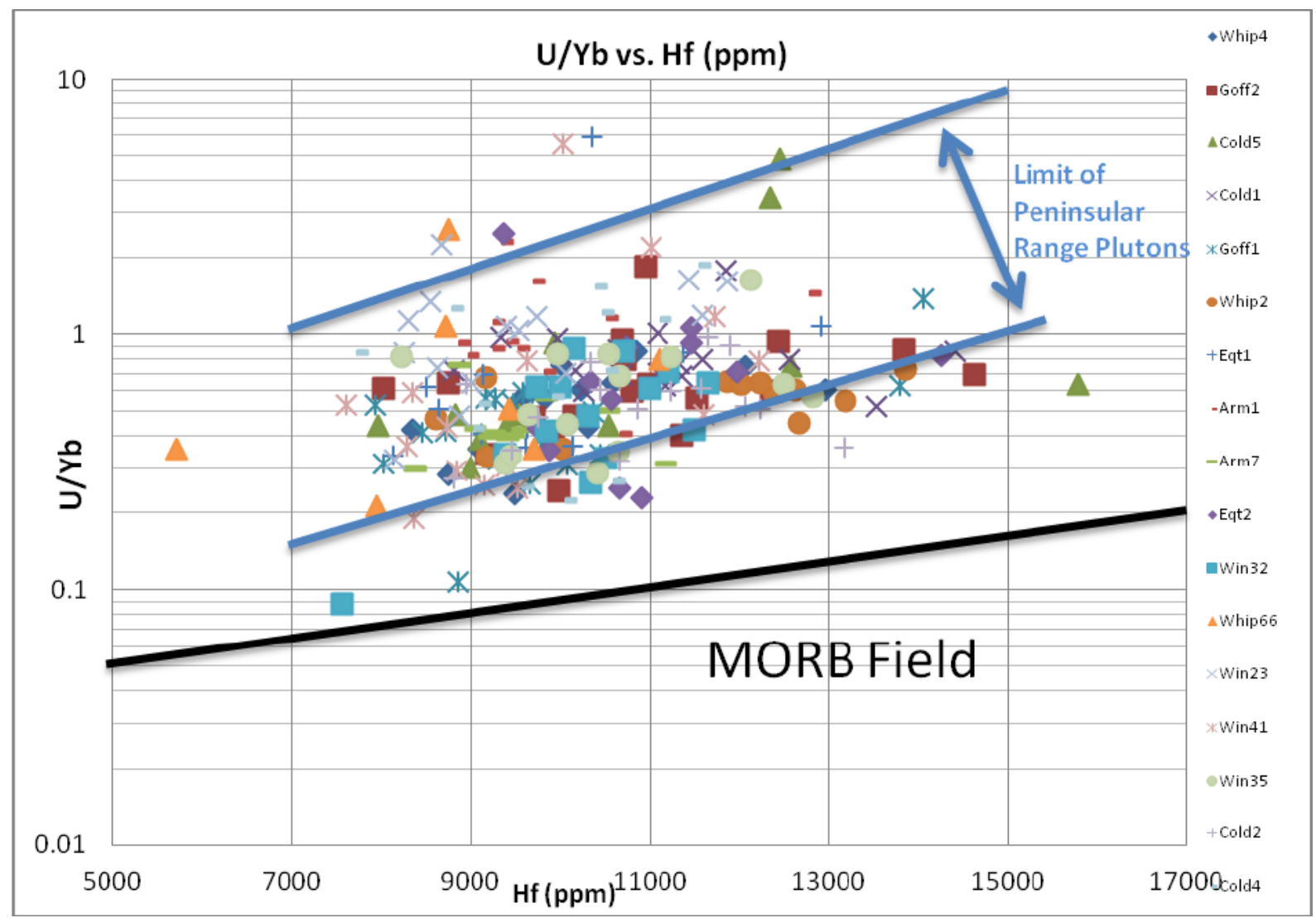

Figure 29. U/Yb ratio versus Hf (ppm) plotting all zircons. Zircons plot above MORB Field. 


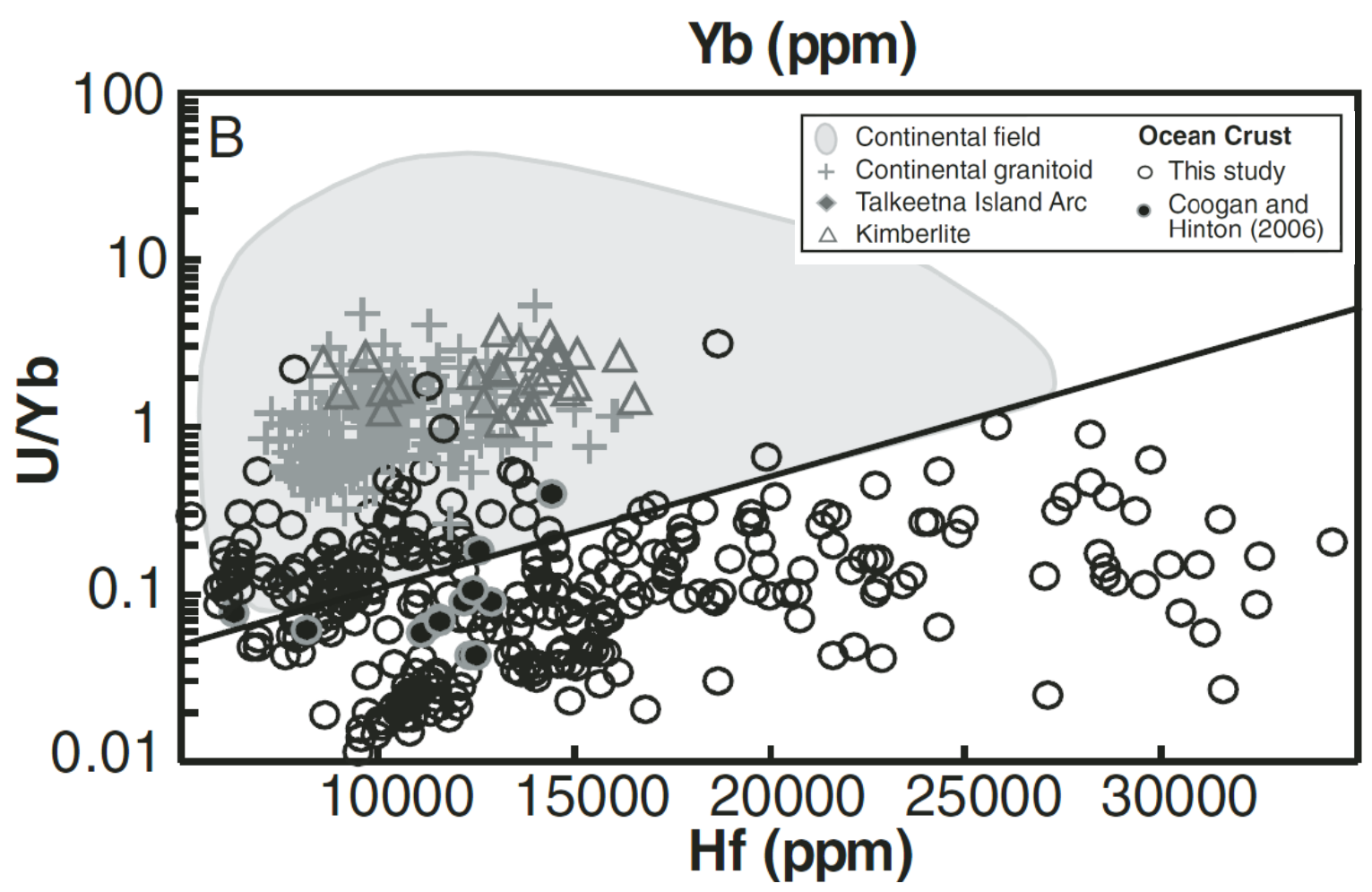

Figure 30. Geochemical discriminant diagrams for zircons. Data from ocean crust zircon, Talkeetna Island Arc, and zircons from granitoid intrusions from northern Chile and eastern Australia, Kimberlites, and oceanic crust (Grimes et al., 2007).

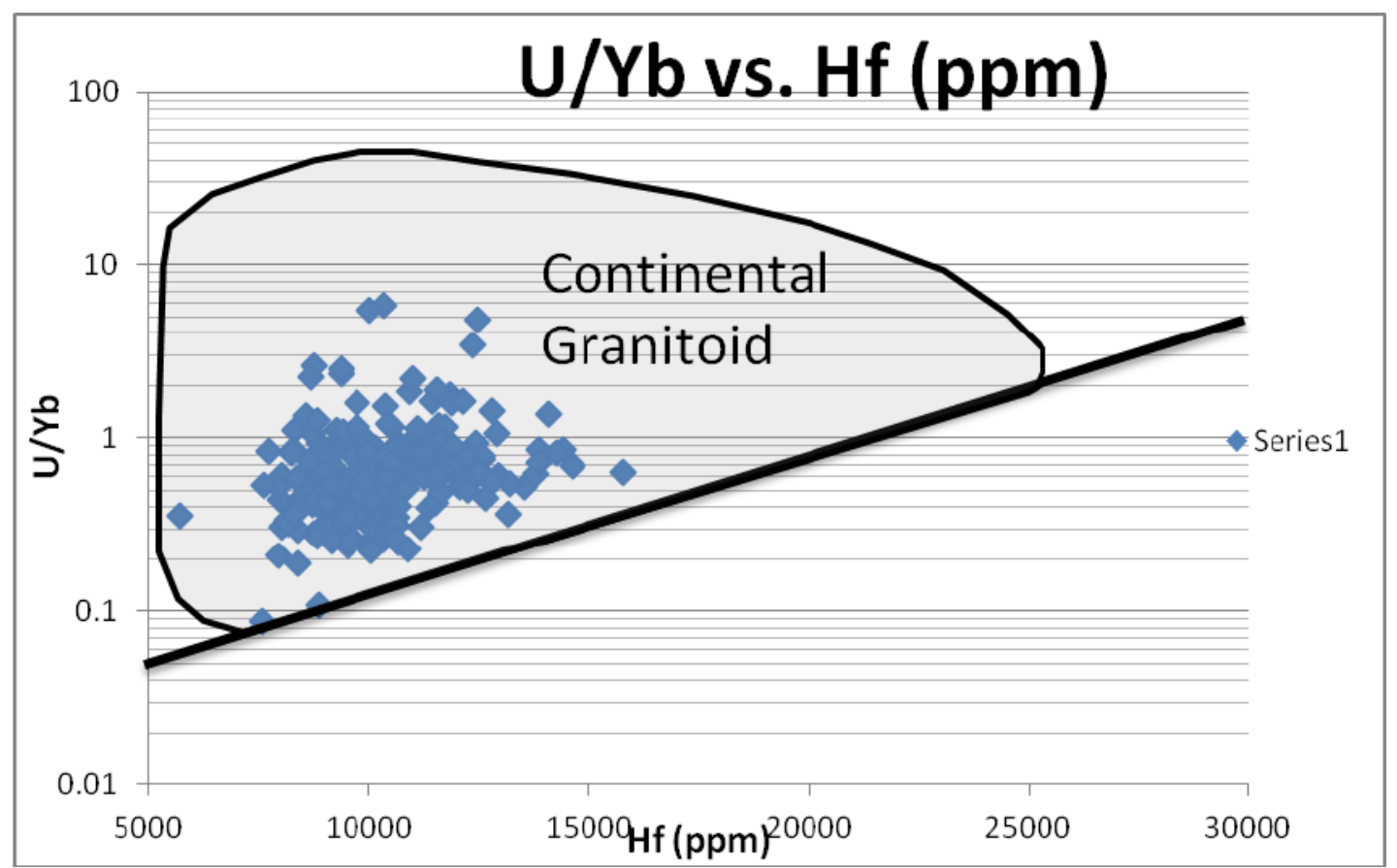

Figure 31. Continental field outlined by Grimes et al., 2007 with all zircons from this study plotted against $\mathrm{U} / \mathrm{Yb}$ vs. Hf (ppm). 
From these diagrams, the zircons tend to plot appropriately in the continental granitoid field, implying the source is from a continental setting, rather than oceanic, which is consistent with the expected source of the Marcellus Ashes in the Acadian arc. Average U/Yb ratios from zircons increase from ocean gabbros (0.18) to continental granitoids (1.07) and kimberlites (2.1). The variation in ratios reflects the variation in average whole-rock $\mathrm{U} / \mathrm{Yb}$ ratios for MORB lavas (0.01-0.1), bulk continental crust (0.7), and kimberlites (4-6) (Grimes et al., 2007).

Along with the idea that all of the zircons sourced from a continental setting, europium ratios can be plotted against $\mathrm{Hf}(\mathrm{ppm})$ to identify minerals in the source. Figure 32 plots all of the zircons comparing $\mathrm{Eu} / \mathrm{Eu}^{*}$ ratios versus $\mathrm{Hf}$ (ppm). All of the zircons plot below 1, which is considered a negative anomaly. Positive Eu/Eu* anomalies fall between 0.9 and 1.7. Negative $\mathrm{Eu} / \mathrm{Eu}^{*}$ ratio anomalies tend to be less than 1 (Hoskin and Schaltegger, 2003).

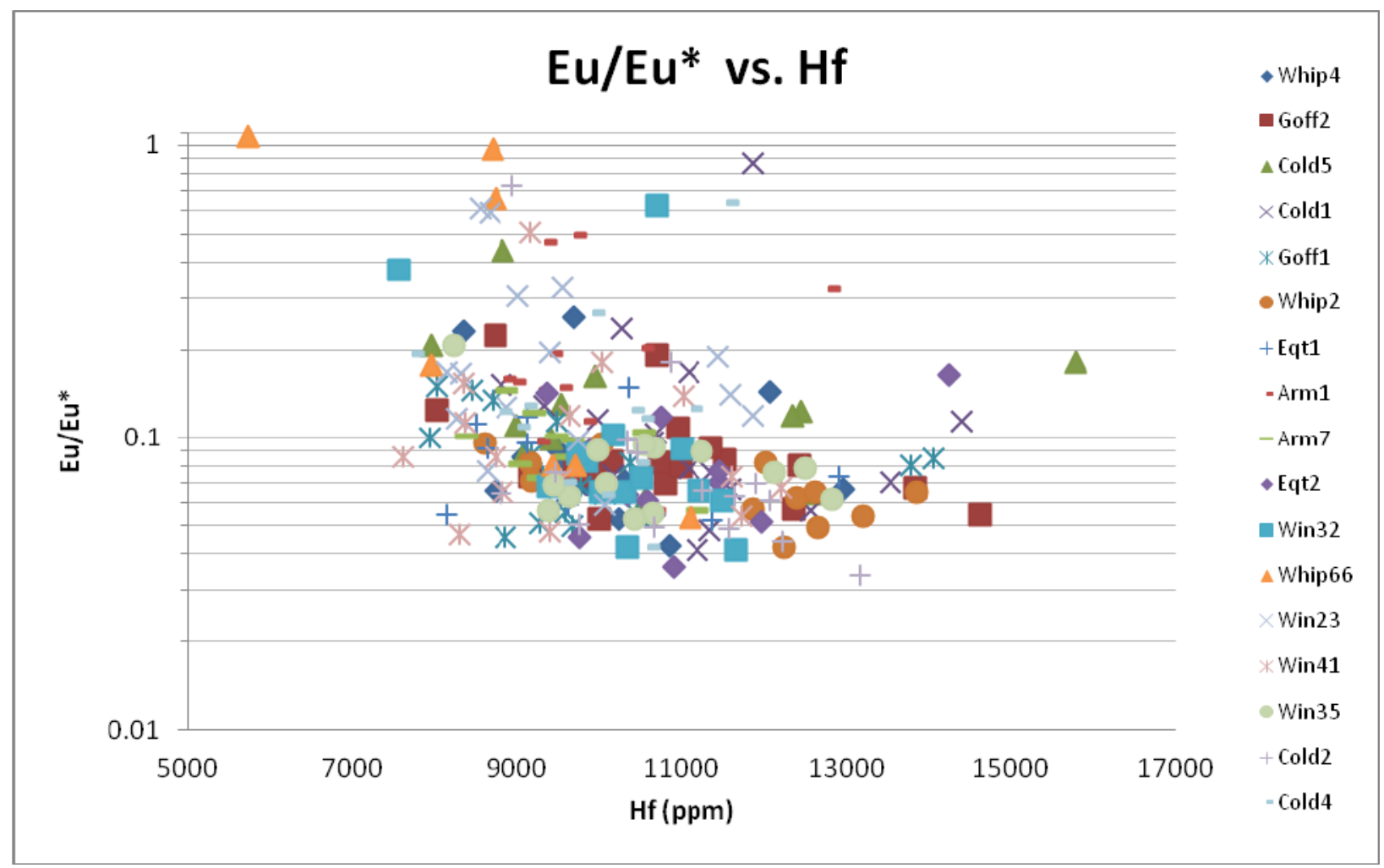

Figure 32. Eu/Eu* vs. Hf (ppm) plots all zircons below Eu/Eu* ratio of 1. Represents negative europium anomaly. 
The negative europium anomaly associated with these zircons is due to feldspar control in the source or melt. As magma crystallizes plagioclase, most of the europium will be trapped within the feldspar mineral. The rest of the magma will then be depleted in europium. Assuming most of the source is containing the feldspar, the rest of the zircons will be depleted in Eu, or have $\mathrm{Eu} / \mathrm{Eu}^{*}$ ratios less than $1 . \mathrm{U} / \mathrm{Yb}$ vs. Hf plots implies that the zircons are represented by a continental granitic field. If the source or melt rock is granitic in origin, feldspar would exist in large enough quantities to pull the europium into the mineral and out of the zircons during crystallization. Several of the zircons plot close to the Eu/Eu* ratio 1 and includes Whip 66 (Standard all zircons were tested against), Win 32, Win 23, and Cold 1. Each of the points was found to be eliminated from the age study due to high Uranium, high $\mathrm{Th} / \mathrm{U}$ ratios, or inherited cores. If the zircon ages are not representative of the Acadian volcanism then their chemistry should not correlate either.

Trace elements $\mathrm{Y} / \mathrm{Yb}$ versus $\mathrm{Th} / \mathrm{U}$ are plotted in Figure 33 to display the zircon fractionation trend during the crystallization process. The zircons follow a trend dipping negatively to the left which represents the direction of fractionation. The zircons with increased $\mathrm{Th} / \mathrm{U}$ ratios around 1 will be the first to crystallize or fractionate out of the melt, followed by the zircons trending to the left. The zircons trending to the left will be more evolved and are considered highly fractionated according to this trend. The high fractionation characteristic is due to sphene crystallization in the melt as an accessory mineral. Garnet influence is occurring with several of the zircons implying as the zircons were fractionating, garnet was as well. The garnet will pull trace element $\mathrm{Yb}$ from the melt, causing zircons to be depleted, allowing the $\mathrm{Y} / \mathrm{Yb}$ ratios to increase (Wooden, 2011, personal comments). Ages of zircons in millions of 
years that were influenced by garnet fractionation are plotted to show the lack of correlation between ages and fractionation trends for these particular zircons.

$\mathrm{Yb} / \mathrm{Gd}$ versus $\mathrm{Th} / \mathrm{U}$ trace elements coincides with Figure 31 displaying fractionation trends of all zircons. Figure 34 plots all zircons using trace elements $\mathrm{Yb} / \mathrm{Gd}$ ratios versus $\mathrm{Th} / \mathrm{U}$ ratios. An increased slope represents zircon fractionation occurring within the melt. Zircons tend to be highly fractionated, which is representative of a continental arc signature. Increased duration of time within a magma chamber allows increased fractionation within the zircon crystals. Low $\mathrm{Yb} / \mathrm{Gd}$ ratios are indicative of garnet fractionation, which is pulling $\mathrm{Yb}$ out of the melt, causing the zircons to be depleted therefore decreasing the $\mathrm{Yb} / \mathrm{Gd}$ ratio. Whipkey Ash 2 and Coldstream Ash 2 tend to exhibit increased zircon fractionation. Coldstream Ash 1 and 5, EQT Ash 1, and Winner Ash 4 have characteristics of garnet influence.

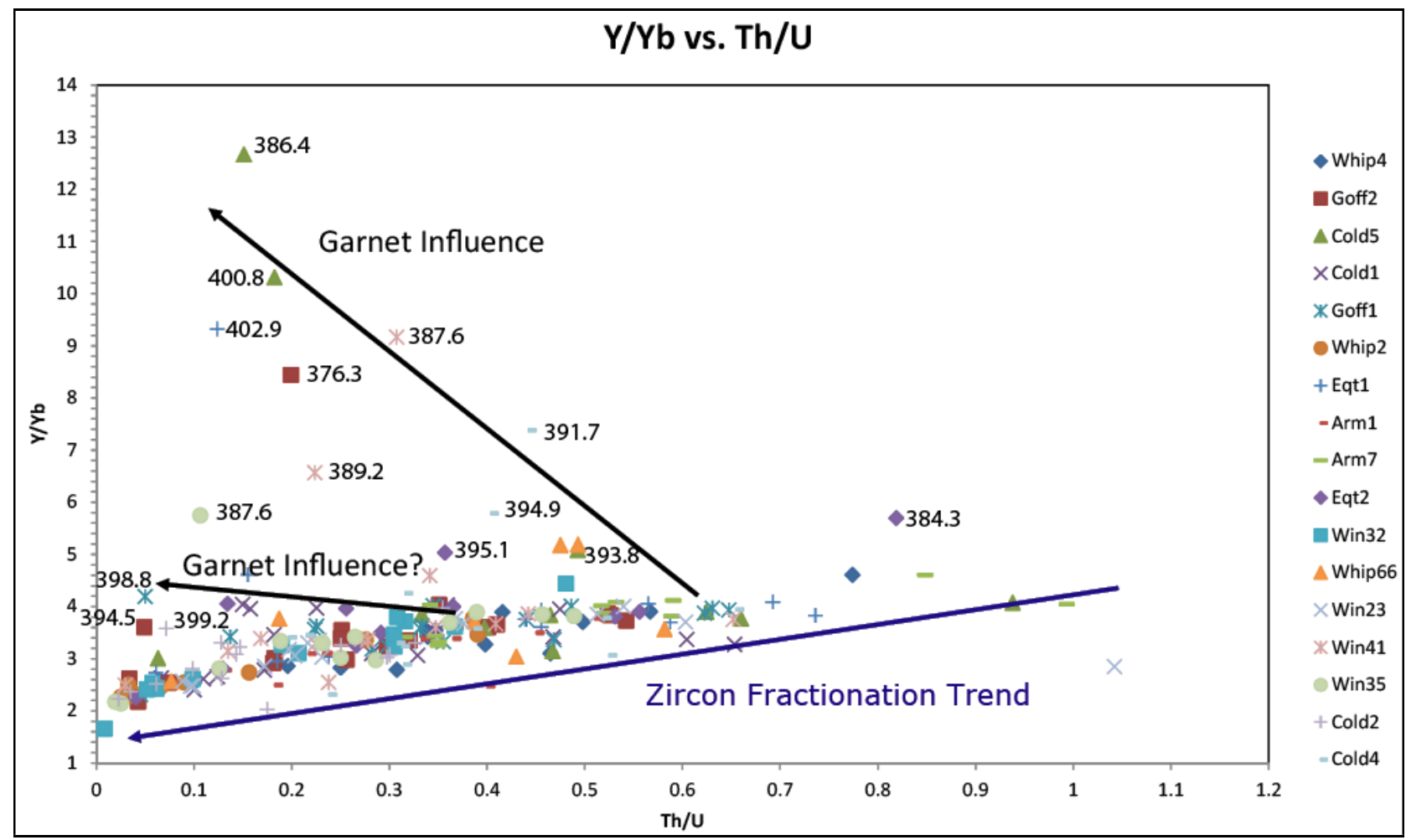

Figure 33. Trace elements $\mathrm{Y} / \mathrm{Yb}$ versus $\mathrm{Th} / \mathrm{U}$ display the zircon fractionation trend during the crystallization process. 


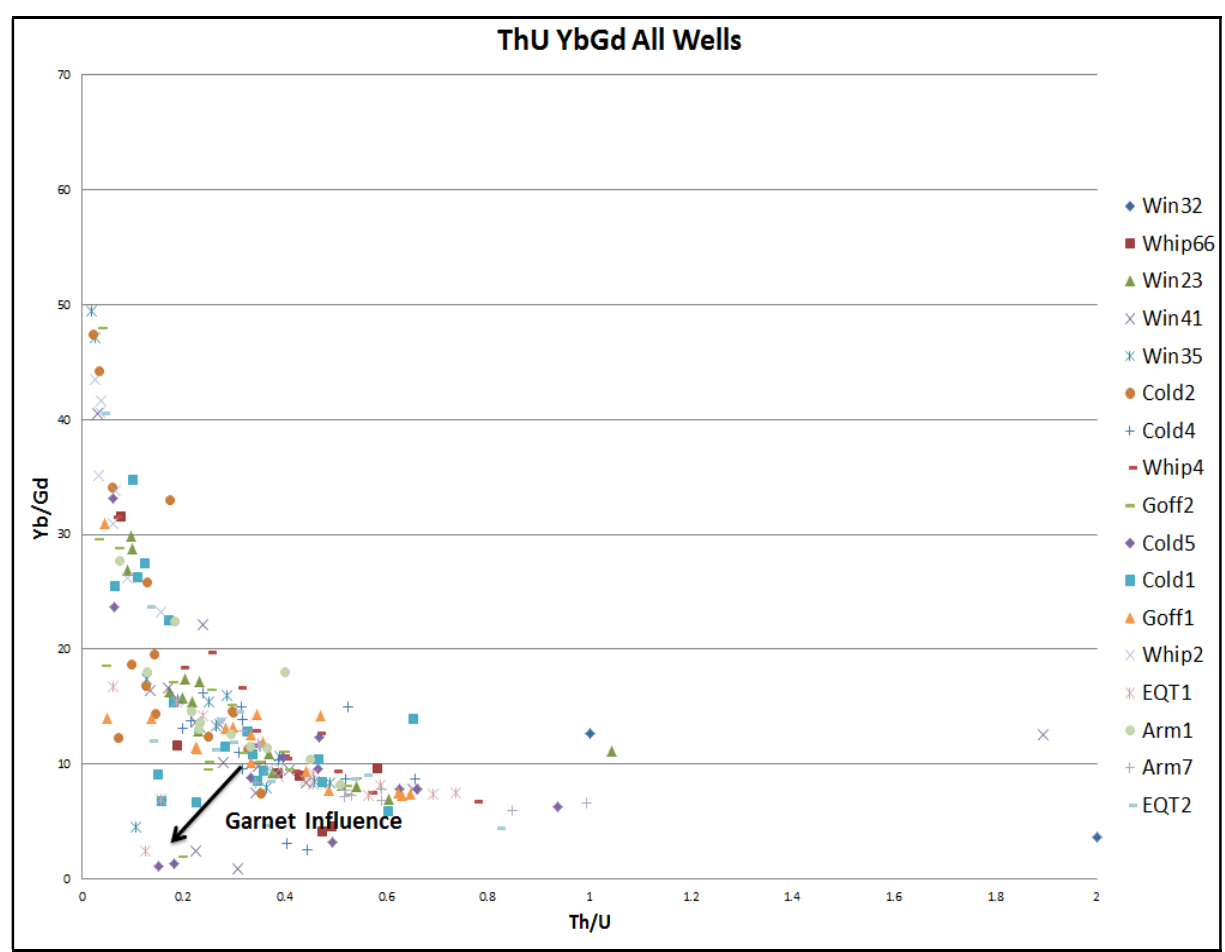

Figure 34. Yb/Gd vs. Th/U ratios of all zircons. Increased slope represents increased zircon fractionation. Zircons that fall from the average trend are distinguishable because of garnet influence in the crystallization process.

Cesium is readily incorporated into zircons due to the similar charge behavior of Ce4+ and $\mathrm{Zr} 4+$ and similarities between the ionic radius (Thomas et al., 2003). Terrestrial zircons commonly show positive Ce anomolies due to this incorporation into the melt. Using Ce in a U/Ce versus Th (ppm) diagram will provide evidence of the type of source, either metamorphic rocks/anatectic melts or magmatic rocks, that the zircons will fall within. Figure 35 shows that most samples fall within the magmatic rock zone. Whip 2, Win32, and Win35 all show increased values of U/Ce that fall within the anatectic zone. This figure provides evidence for both crustal melting and a magma source which is consistent with continental arc systems (Horton, 2011).

Cesium can also be plotted as a ratio as $\mathrm{Ce} / \mathrm{Sm}$ versus $\mathrm{Hf}(\mathrm{ppm})$ to provide evidence of a crustal source. The line shown in Figure 36 displays the Lower Limit Peninsular Range Plutons. Most points fall below this line which is not consistent with the rest of the plots from this data. In 
this example, Ce was pulled out in the melt by some mineral(s) during fractionation. This specific anomaly could possibly identify a pluton body or eruption source.

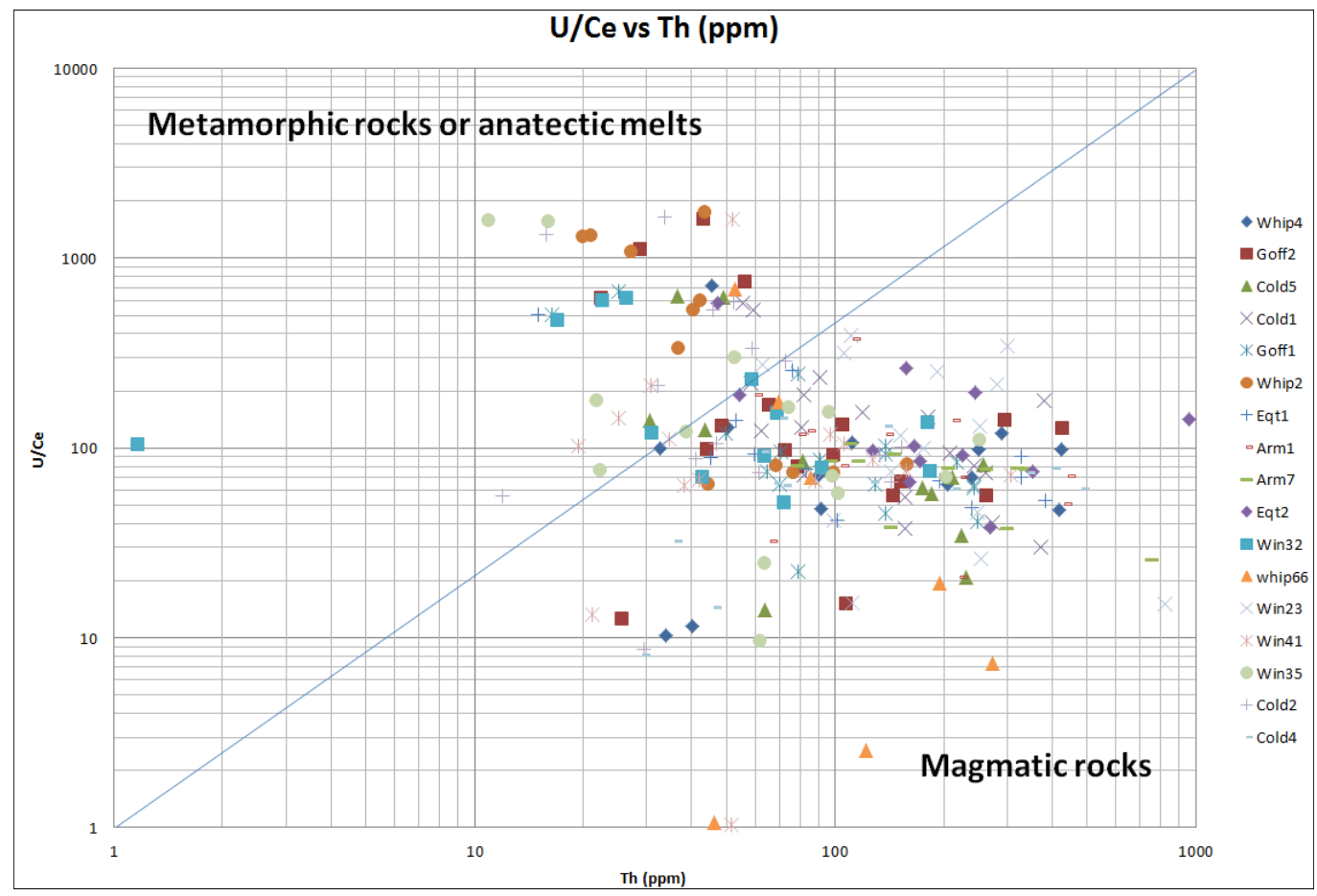

Figure 35. U/Ce vs. Th (ppm) plot shows difference between metamorphic rocks or anatectic melts vs. magmatic rocks. Most points fall within magmatic rocks.

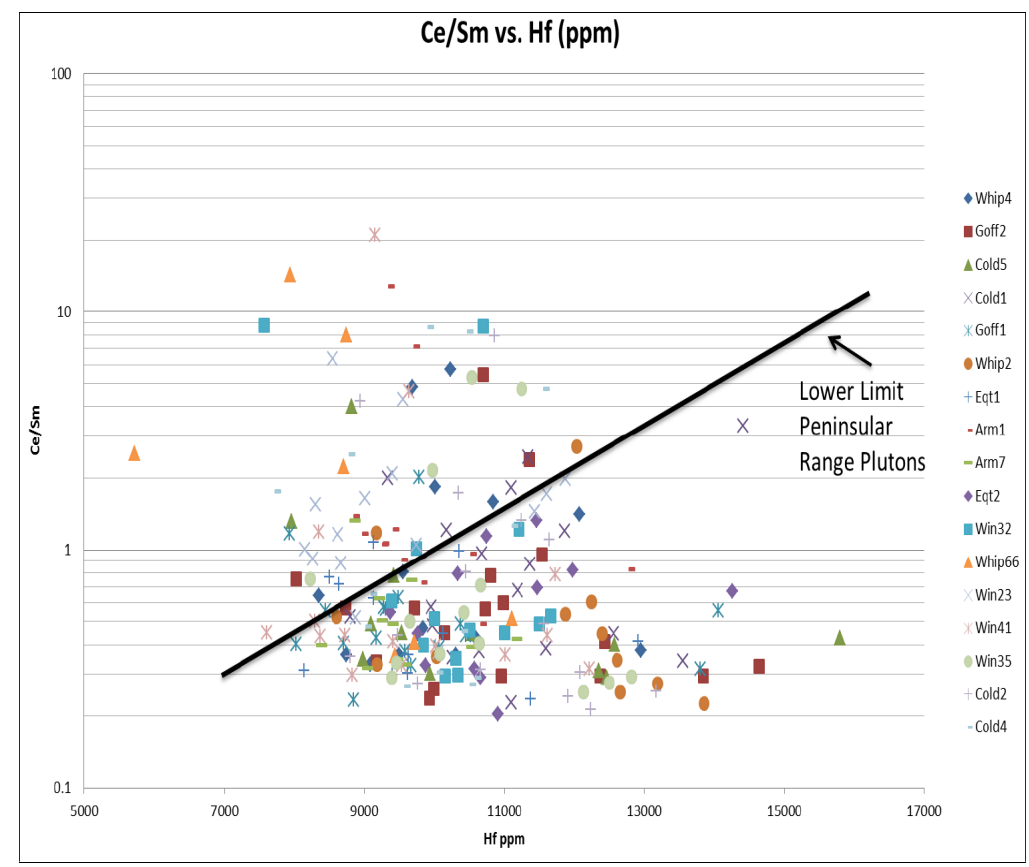

Figure 36. Ce/Sm vs. Hf (ppm) shows points plotting beneath the Lower Limit Peninsular Range Pluton line. Ce was pulled from the melt during fractionation. 


\section{Rare Earth Element Concentration Plots}

Rare earth element (REE) concentration plots were completed for each ash horizon dated using the SHRIMP RG method (All diagrams can be found in Appendix I). Each individual zircon represents a series within the REE concentration plot. The overall trend visible in all REE concentration plots created for all ashes displays incorporation of heavier REE over light REE. Figure 37 plots the Winner 41 Ash 4 REE concentrations for each zircon measured. The concentrations tend to increase for the Heavy Rare earth elements (HREE) versus the Light Rare Earth Elements (LREE). This is explained by the compatibility of REEs in the zircon lattice (Grimes et al., 2007). Contraction of the trivalent lanthanide REEs with increasing atomic number results in the heavier REEs ionic radii that are comparable to zircons ionic radii. The HREE will then be incorporated more readily over the LREE. The resulting diagrams will be then consistent, showing LREE depleted patterns and HREE enriched patterns. Figure 38 is from Grimes et al, 2007, plotting rare earth element concentrations for ocean crust zircons normalized to $\mathrm{C} 1$ chondrite. Figure 37 is important for comparison to depict where the zircons of the Appalachian basin fall within the concentration plots. The dashed field outlined in Figure 38 represents zircons from continental rocks, which coincides with all of the REE concentration plots produced in this study. All of the REE concentration plots produced display characteristics of zircons that would plot in a zone outlined by continental rock, which correlates with the previous conclusions met from the trace element diagrams.

Anomalies are visible in the REE zircon concentration plots, including a positive Cesium anomaly and negative Europium anomaly. Figure 37 and Figure 39 displaying Winner 41 Ash 4 and Coldstream Ash 1 as well as all REE zircon concentration plots display these anomalies. This phenomenon is typical of unaltered igneous zircons. Positive Ce-anomalies were first 
documented from Indian beach sands and syenite and was then contributed to the presence of Ce4+ in the melt (Hoskin and Schaltegger, 2003). The magnitude of the Ce-anomaly is attributed to the amount of Cesium in the melt while crystallization is taking place, which is then compared to the $\mathrm{Ce} 4+/ \mathrm{Ce} 3+$ ratio as a function of oxygen fugacity. Europium anomalies found in these particular ashes are confirmed to have formed from the presence of feldspar during crystallization. Feldspar will pull europium from the melt, depleting the zircons of europium causing a negative anomaly. Trace element diagrams previously provided prove there is europium depletion in each individual zircon measured. Figure 39 plotting Coldstream Ash 1 REE exhibits a Series 9 (Zircon 9) lanthanide (La) anomaly, which increased concentrations of lanthanide. This may be possible for some zircons measured to have increased lanthanide concentrations, but Zircon 9 is the only zircon to exhibit this behavior and is inconsistent with the rest of the data (Layton-Matthews, 2003).

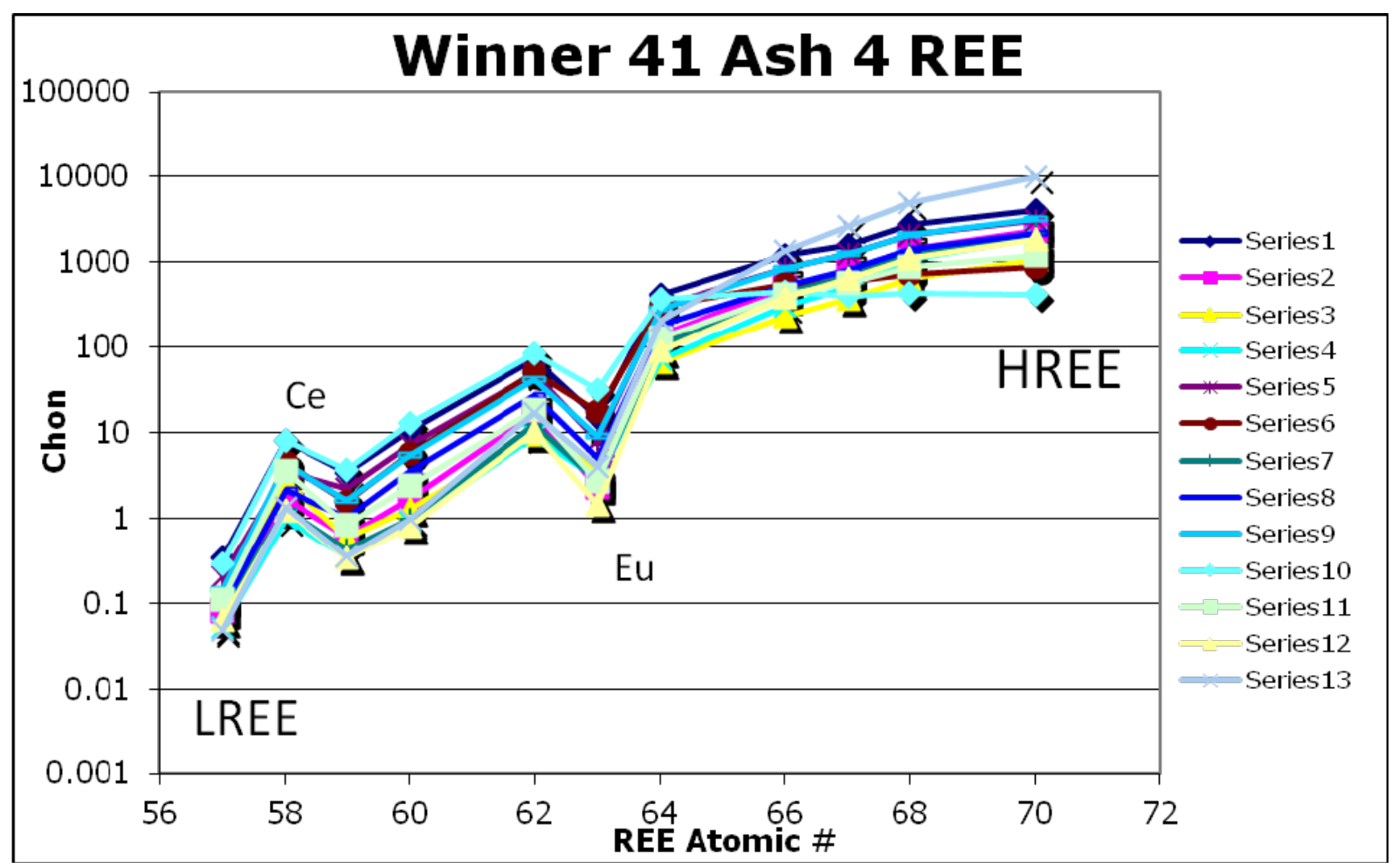

Figure 37. Winner 41 Ash 4 REE zircon concentrations diagram. Displays incorporation of HREE over LREE. Ce and Eu anomalies exist in all zircons measured. 


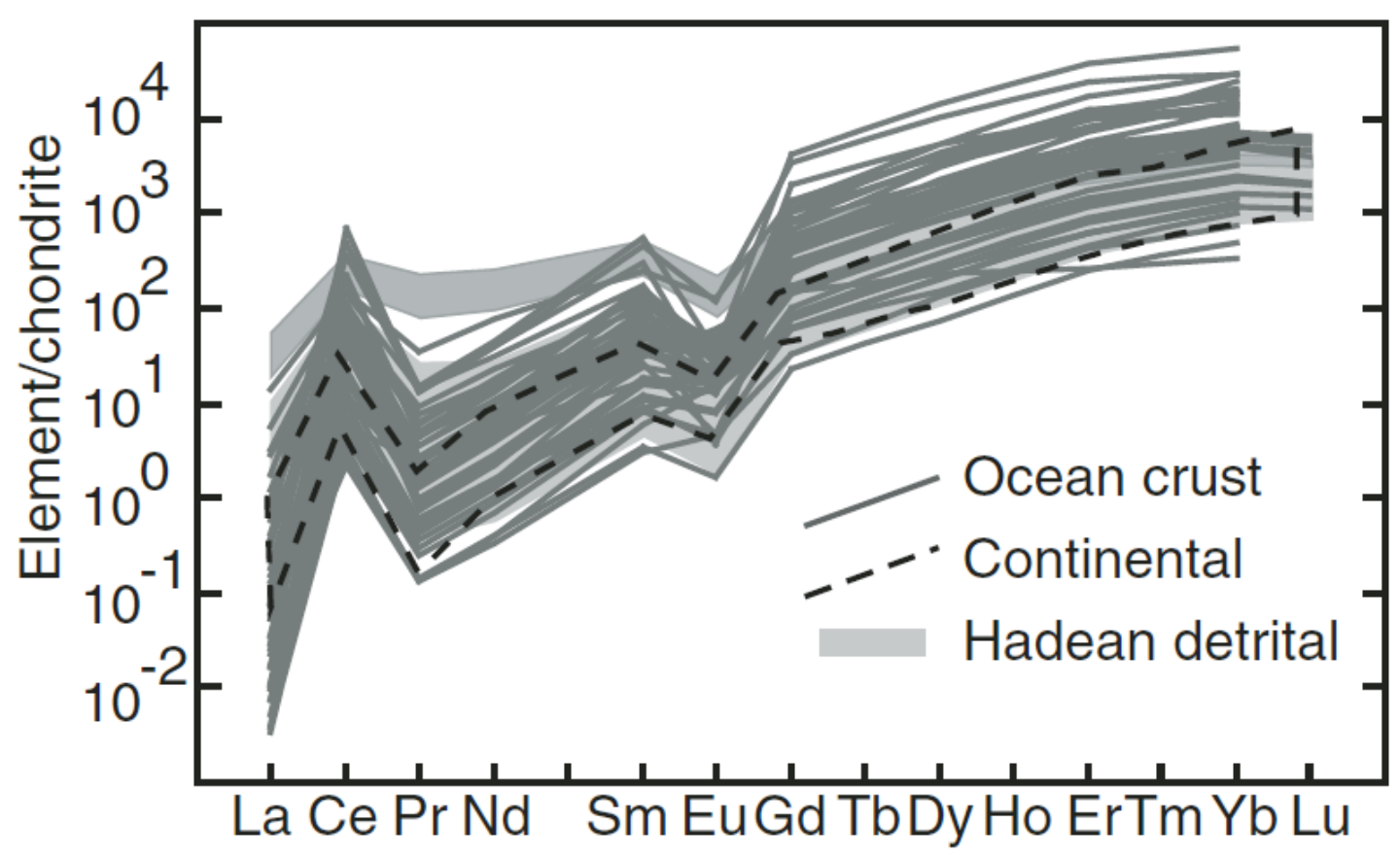

Figure 38. Rare earth element concentrations for ocean crust zircon normalized to $\mathrm{C} 1$ chondrite. Dashed field represents zircons from continental rocks (Grimes et al, 2007).

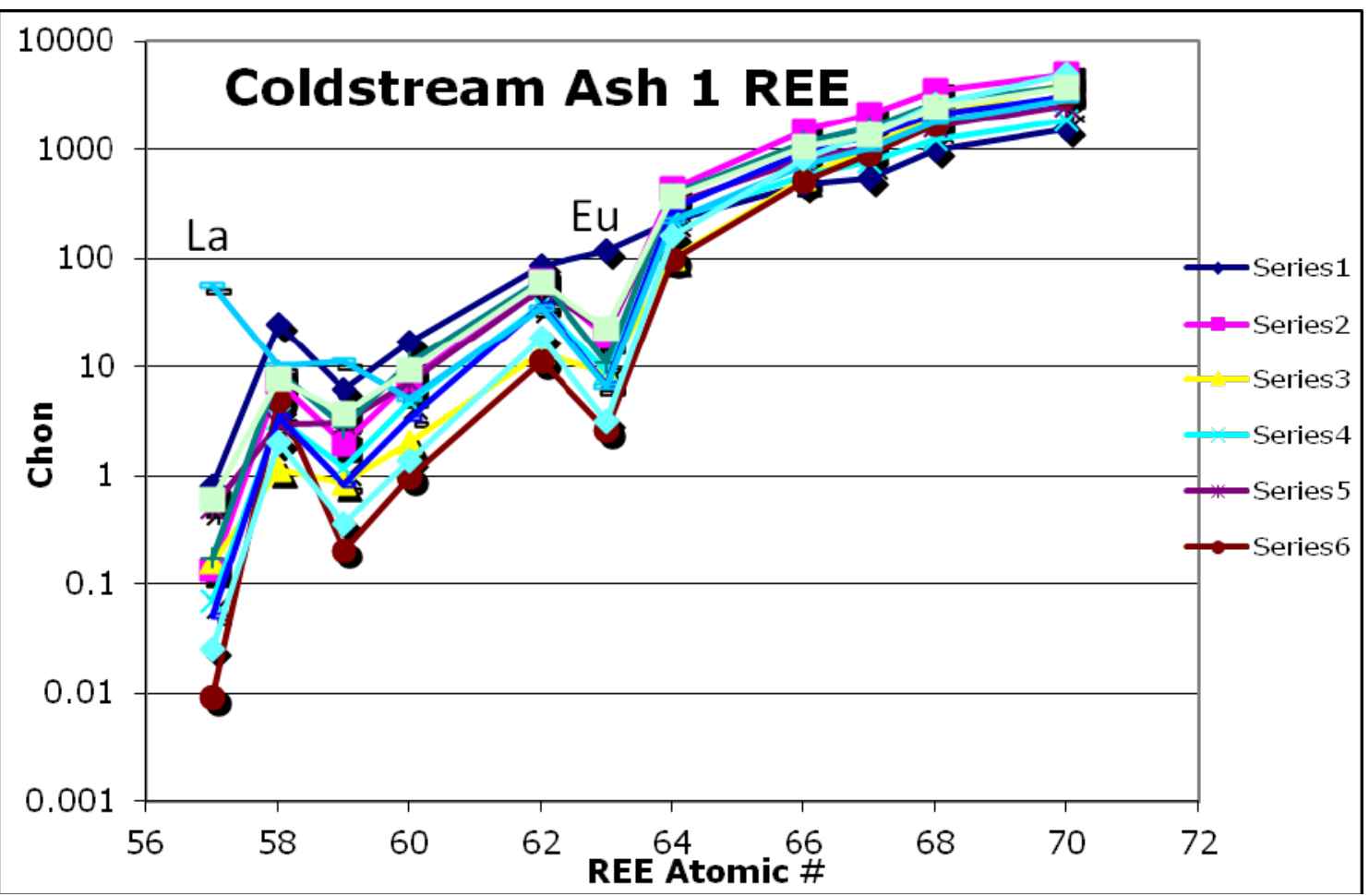

Figure 39. Coldstream Ash 1 REE zircon concentrations diagram. Displays incorporation of HREE over LREE. Ce and Eu anomalies exist in all zircons measured. La and Eu anomalies exist in Series 9 and Series 1. 


\section{DISCUSSIONS AND CONCLUSIONS}

\section{Age Data Conclusions}

Initial interpretations are made relating to the ash horizons before dating using the SHRIMP RG method. It is assumed that each ash layer that has been described represents one eruption. All of the zircons that exist within that layer are assumed to have been erupted at the same time. Once the zircons from each layer were dated, the results displayed a wide range of ages for zircons within one ash layer. On one ash horizon, zircons concordant ${ }^{206} \mathrm{~Pb} /{ }^{238} \mathrm{U}$ ages range in ages from 10-20 million years. This does not follow the initial assumptions that all zircons from the same horizon should be the same age. The explanation for this is that the $10-20$ million year age differences between zircons represent the longevity of the arc magmatic system. The zircons will form in the magmatic chamber over the duration of time, allowing fractionation to occur. Fractionation within zircons is displayed using the trace element $\mathrm{Y} / \mathrm{Yb}$ vs. Th/U and Th/Y vs. Yb/Gd plots in Figure 33 and Figure 34.

In four ash horizon including Coldstream 1 Ash 1, Goff \#55 1 and 2, and Armstrong \#1 Ash 1 all exhibit two different groupings of coherent age clusters. For example, Figure 22 displays Goff \#55 Ash 2 plotted with an older cluster and younger cluster of zircon ages per one horizon. Each cluster has a high probability of $95 \%$ confidence, meaning the probability that those zircons fall within a window of ages is high. Problems with choosing which cluster is more accurate depend on error, uranium content, and lead loss. To resolve this problem, the youngest cluster of ages for one ash horizon is chosen as the age of eruption. The youngest coherent ages for zircons on one horizon is accepted as the last moment that the zircons were forming in the magmatic system, and were then expelled at that age.

After compiling all of the zircon concordant ${ }^{206} \mathrm{~Pb} /{ }^{238} \mathrm{U}$ ages, binned frequency diagrams and probability density plots are used to attempt to display a correlation between zircon ages. 
Major peaks of increased frequency of ages are found at 384.7, 390.0, and 394.95 Ma. Minor peaks are found at $383.4,399.0,402.85$, and 408.0 Ma. The major peak ages are interpreted to be possible eruption ages. This interpretation implies that there are multiple eruption events over the course of 384.7 and 408.0 Ma.

In the case of the Armstrong \#1 well, two ashes date relatively young in age at $384.2 \mathrm{Ma}$ for Ash 1, and 380.9 Ma for Ash 7. Ash 1 is stratigraphically higher than Ash 7 and should be younger, but does not show this in the example. The errors for the ashes are $384.2 \pm 2.4$ and $380.9 \pm 2.0$. If errors are considered in this example, then it is possible that the stratigraphically higher ash 1 is really $381.8 \mathrm{Ma}$ and ash 7 is $382.9 \mathrm{Ma}$, which follows the Law of Superposition (Leveson, 2006). There are 5 intermediate ashes in the well that have not been dated and should help resolve the problem. In some cases, the ages may be older when stratigraphically higher if there are areas of faulting or repeating section. This study does not incorporate a detailed study of faulting, which may be considered in future studies. 


\section{Foreland Basin Conclusions}

The ages in millions of years for the base of the Marcellus Shale are plotted on a map showing each well location. Figure 40 displays the ages of the lowermost ashes analyzed. A general trend is visible in the ages showing a younger age progression in the southeast direction. EQT 511391 well contains the oldest ash horizon at the base of the Marcellus Shale at 402.1 million years old. At the time of deposition, an eruption occurred during adjacent subduction to the southeast. The eruption age is recorded as 402.1 Ma and is observed in the stratigraphy due to the preservation and depositional environment at that time. Preservation of ashes occurs in locations that have a low enough energy not to disperse any incoming ash materials (Ver Straeten, 2004).

As subduction continues, another eruption event is recorded in two places located at Goff \#55 and Coldstream \#1 at around 396.8 Ma. The age at these two wells represents the base of the Marcellus Shale and the site of black shale deposition has moved since the previous eruption. Moving even further to the southeast, St. Whipkey \#1 and Winner 4-8 well locations show another eruption age that is correlative between the two wells at around $389 \mathrm{Ma}$. The farthest well to the southeast is Armstrong \#1 and is found to have an eruption age of $380.9 \mathrm{Ma}$. This is the youngest base of the Marcellus Shale recorded and represents the location of the onset of black shale deposition at that location. Following this trend developed from the ages of the base of the Marcellus, it is interpreted that the base is diachronous. The beginning of deposition of the Marcellus did not occur uniformly across the entire basin, but at different locations beginning in the northwest and trending to the southwest. Given that the ages from all ashes range from 380.9 \pm 2.0 to $403.8 \pm 4.0 \mathrm{Ma}$ and the base of the Marcellus is diachronous, the new proposed ages for 
Marcellus deposition is between Frasnian to Emsian. These ages differ from previous studies that limited the Marcellus deposition to Givetian to Emsian.

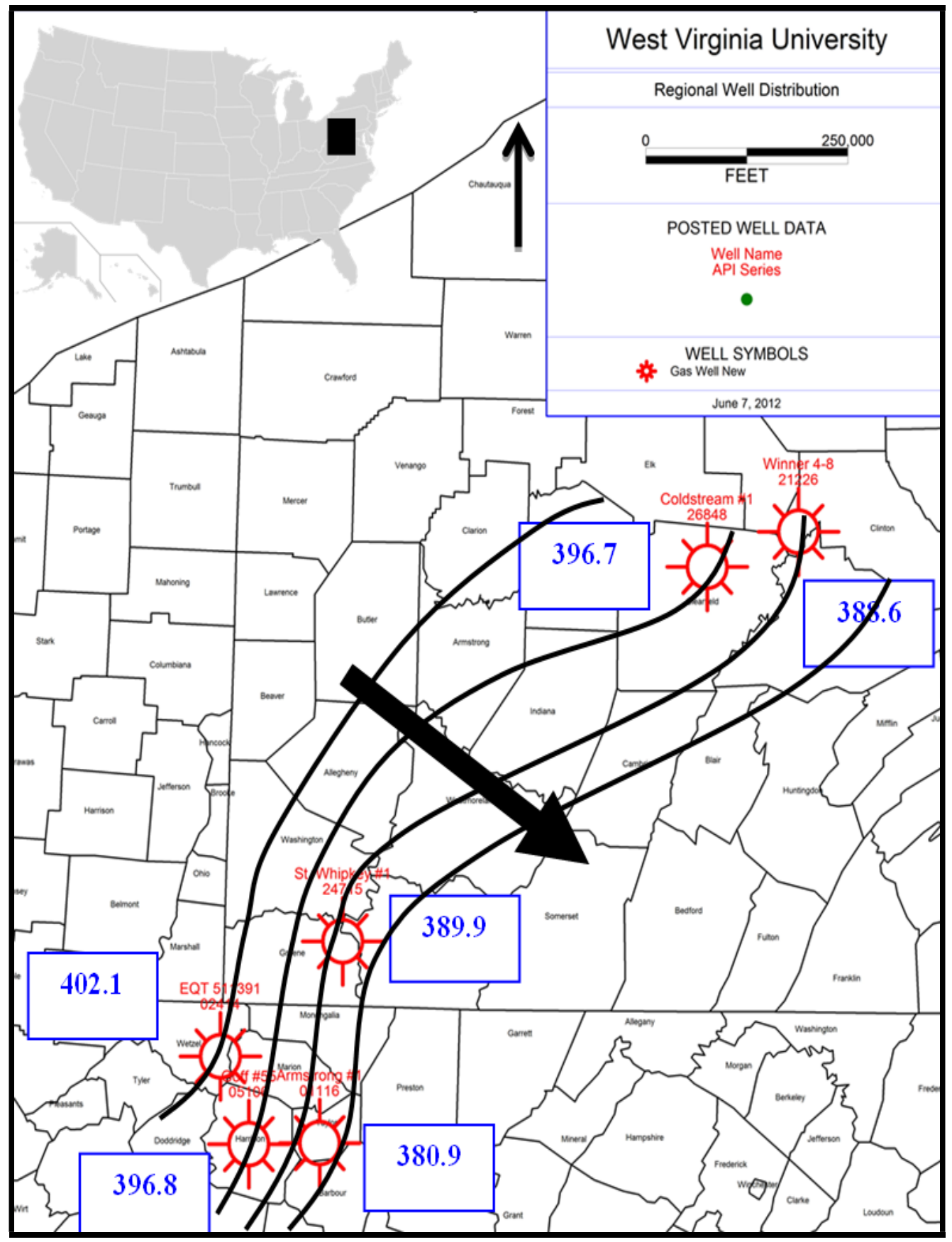

Figure 40. Displays the age of the lowermost ashes analyzed. Ages are in millions of years in blue and do not include errors. A-A' shows the cross section in Figure 39 and shows the direction of the black shale deposition as time progresses. 
Sedimentation rates during the time of Marcellus deposition were calculated for the six wells used in this study. The sedimentation rates averaged to range between $0.98 \mathrm{ft} / \mathrm{my}$ to 21.7 $\mathrm{ft} / \mathrm{my}$ and are comparable to other studies of organic rich black shale. Relative to a Deep Sea Drilling Project completed Barker, 2001, the Marcellus Shale is interpreted to fall in the category of a deep water environment with little sediment accumulation. If the environment has a low enough energy, fine grained ash beds will be preserved. Lower sedimentation rates allow higher preservation of organic carbon increasing TOC values. The Marcellus Shale is black shale that has high TOC characteristics and falls within realistic sedimentation rate values at time of deposition. 


\section{Source Conclusions}

Trace Element and Rare earth element plots were created to understand the crustal evolution and type of source rock that the zircons originated from. U/Yb vs. Hf (ppm) trace element plots in Figure 31 confirm that all of the zircons fall within the continental granitoid field outlined by Grimes et al., 2007. The continental granitoid field implies the zircons originated from a continental crustal setting rather than an oceanic setting. This correlates with the idea that the source is of a continental arc magmatic origin.

The Eu/Eu* vs. Hf plot shown in Figure 32 displays a negative Europium anomaly, which is directly related to a feldspar control. Europium tends to be depleted in zircons if there is an increased concentration of feldspar in the melt. If feldspar is present, it helps support the idea that the source rock is of arc magmatic continental origin.

Rare earth element concentration plots created for each ash horizon display characteristics of continental rock including positive cesium anomalies, negative europium anomalies, and concentration plots that fall within the continental rock zone as opposed to oceanic crustal rocks. The concentration of each REE in Figure 37 compared to the concentrations in Figure 38 display that the zircons in this study have equivalent REE values of continental crust, enforcing the assumption that the source is an arc magmatic continental origin.

Compiling all of the information from the trace element and rare earth element diagrams, it is interpreted that all of the zircons exhibit similar behaviors. All of the zircons from every ash horizon fall within the same significant type of source rock. There are no major outliers found on any plot. It is concluded that all of the zircons are of similar origin; therefore they are derived

from one type of source and source rock. Considering this information with the zircon ${ }^{206} \mathrm{~Pb} /{ }^{238} \mathrm{U}$ age data, it is concluded as well that there were multiple eruption events from one source area. 
Zircons that contained inherited cores were dated with ages between $1001.5 \pm 6.6 \mathrm{Ma}-1517.2 \pm$ 22.9 Ma are interpreted to have sourced from the underlying basement material derived from the Grenville Orogeny. The ages of the zircons correlate with the age of the Grenville Province. The location of the source has currently not been concluded, but the direction of the source can be predicted from trade winds and paleo-atmospheric circulation. During the Middle Devonian the direction of the trade winds and atmospheric circulation drive the wind direction to travel northwest below the equator in the southern hemisphere (Parrish, 1982). In respect to the foreland basin during deposition, the winds would be traveling from the source in the southeast direction, causing volcanic ash to travel to the northwest into the basin. Figure 2 displays the direction of the winds during deposition in respect to the basin. This implies the source was from the southeast side of the basin. 


\section{REFERENCES}

Aronson, J., Lewis, T., 1994, “Ages of Detrital White Mica from Devonian-Pennsylvanian Strata of the North Central Appalachian Basin: Dominance of the Acadian Orogen as Provenance", The Journal of Geology, v. 102, no. 6, p. 685-696.

Arthur, M.A., Sageman, B.B., 1994, "Marine Black Shales: Depositional Mechanisms and Environments of Ancient Deposits." Annual Review of Earth and Planetary Sciences v. 22: p. 499-551.

Barker, C., 2001, "Deposition of sedimentary organic matter in black shale facies indicated by the geochemistry and petrography of high-resolution samples, Blake Nose, western North Atlantic". Geological Society, London, Special Publications. v. 183. p. 49-72.

$<$ http://sp.lyellcollection.org/content/183/1/49.full.pdf html>.

Bartholomew, A.J., Brett, C.E., 2006, "Coordinated faunal turnover in the Middle Devonian of eastern North America”. Geological Society of America (Annual Meeting), Abstracts with Programs, v. 38, no. 6.

Blakey, R. 2010, "North American Paleogeography". <http://www2.nau.edu/rcb7/nam.html>

Brett, C.E., Bartholomew, A.J., Baird, G.C, 2007, "Biofacies recurrence in the Middle Devonian of New York State: An example with implications for habitat tracking" Palaios, v. 22, p. 306-324.

Boyce, M. L. 2010, "Sub-surface Stratigraphy and Petrophysical Analysis of the Middle Devonian Interval of the Central Appalachian Basin; West Virginia and Southwest Pennsylvania," unpublished PhD Dissertation, West Virginia University, p.144.

Bowring, S.A., Schmitz, M.D., 2003, "High-precision U-Pb zircon geochronology and the stratigraphic record." Mineralogical Society of America Reviews in Mineralogy and Geochemistry, v. 53 no. 1 p. 305326.

Erenpreiss, M.S., Wickstrom, L.H., Perry C.J., Riley, R.A., Martin, D.R., 2011, "Regional organicthickness map of the Marcellus Shale with additional organic-rich shales beds in the Hamilton Group included for New York, Pennsylvania, and West Virginia" Ohio Department of Natural Resources, Division of Geological Survey.

< http://www.dnr.state.oh.us/LinkClick.aspx?fileticket=5TdkdpILE4c\%3D\&tabid=23014>

Ettensohn, F.R. 1987, "Rates of Relative Plate Motion during the Acadian Orogeny Based on the Spatial Distribution of Black Shales". Journal of Geology, v. 95 no. 4, p. 572-82.

Ettensohn, F.R., 2004, "Modeling the Nature and Development of Major Paleozoic Clastic Wedges in the Appalachian Basin, USA", Journal of Geodynamics. v. 37, p. 657-681.

Maryland Geological Survey, 1968, "Allegheny Plateau and Valley and Ridge".

<http://www.mgs.md.gov/esic/geo/lgdalleg.html>

Faure, G. 1986. "Principles of Isotope Geology.” New York: Wiley \& Sons .p. 1-589. 
Fedo C., Sircombe K., Rainbird R.,2003, “Detrital zircon analysis of the sedimentary record”. In: Hanchar JM, Hoskin PWO, editors. Mineralogical Society of America, Reviews in Mineralogy and Geochemistry. v. 53. p. 277-303.

Fettke, C.R., 1961, "Well-sample descriptions in northwestern Pennsylvania and adjacent States." Pennsylvania Geological Survey, 4th ser., Mineral Resource Report v. 40, p. 691.

Geologic Map Legends, 1968, "Allegheny Plateau and Valley and Ridge". Geologic Map of Maryland. Maryland Geological Survey.

<http://www.mgs.md.gov/esic/geo/lgdalleg.html>

Grimes, C.B., John, B.E., Kelemen, P.B., Mazdab, F.K. Wooden, J.L., 2007, " Trace element chemistry of zircons From oceanic crust: A method for distinguishing detrital zircon provenance". Geological Society of America. v. 35, no. 7, p. 643-646.

Horton, F.M.., 2011, "Geochronology and Zircon Geochemistry of Greater Himalaya Leucogranites in Zanskar, NW India." San Francisco State University. p. 1-104.

<http://www.uweb.ucsb.edu/ fhorton/Horton_ThesisComplete.pdf>.

Hoskin, P.W., Schaltegger, U., 2003, "The composition of zircon and igneous and metamorphic petrogenesis." Reviews in Mineralogy and Geochemistry v. 53, p. 27-62.

Ibach, L.E.J., 1980, "The Relationship between Sedimentation Rate and Total Organic Carbon Content in Ancient Marine Sediments". Oregon State University.

$<$ http://ir.library.oregonstate.edu/xmlui/bitstream/handle/1957/27702/IbachLynneEJohnson1980.pdf?sequ ence $=1>$

Johnson, J.G., Klapper, G., Sandberg, C.A., 1985, "Devonian eustatic fluctuations in Euramerica" Geological Society of America Bulletin, vol. 96, p. 567-587.

Lash, G. G., 2008, "Stratigraphy and fracture history of Middle and Upper Devonian succession, western New York significance to basin evolution and hydrocarbon potential" Pittsburgh Association Petroleum Geologists Spring Field Trip, p. 88.

Lash, G. G., Engelder, T., 2011, "Thickness Trends and Sequence Stratigraphy of the Middle Devonian Marcellus Formation, Appalachian Basin: Implications for Acadian Foreland Basin Evolution." American Association of Petroleum Geologists. v. 95, no. 1, p. 61-103.

Layton-Matthews, D., 2003, "Gangue, Mineral Deposits Division." Gangue, Mineral Deposits Division. i. 76.

<http://www.sfu.ca/mdd/gangue/Gangue76.pdf>

Leveson, D.J., 2006, "Determining Relative Age from the Rock Record.", The Law of Superposition. <http://academic.brooklyn.cuny.edu/geology/leveson/core/topics/time/froshlec8.html>

Lindholm, R,C., 1967, "Petrology of the Onondaga Limestone (Middle Devonian), New York" unpublished PhD thesis, Johns Hopkins University, p. 188.

Ludwig K.R , 2001, “Isoplot, Squid 1.02” A user's manual: Berkeley Geochronology Center Special Publication no. 2. 
Parrish, J.T., 1982, "Upwelling and petroleum source beds, with reference to the Paleozoic" American Association of Petroleum Geologists Bulletin, v. 66, p. 750-774.

Sageman, B., A. Murphy, J. Werne, C. Ver Straeten, D. Hollander, and T. Lyons, 2003, “A tale of shales; the relative roles of production, decomposition, and dilution in the accumulation of organic-rich strata, Middle-Upper Devonian, Appalachian Basin” Chemical Geology, v. 195, p. 229-273.

Sexton, R., 2011, "Sequence stratigraphy, distribution and preservation of organic carbon, and reservoir properties of the Middle Devonian Marcellus Shale, of the central Appalachian basin; northern West Virginia and southwestern Pennsylvania.", unpublished MS Thesis Dissertation, West Virginia University

SHRIMP RG Laboratory, 2012, "USGS, Stanford School of Earth Sciences." USGS, Stanford School of Earth Sciences.

$<$ http://shrimprg.stanford.edu/>.

Streepey, M., 2004, "Geological Society of America." Geological Society of America. v. 197, p. 391-410. <http://globalchange.umich.edu/ben/Publications/04_GSAmemoir_streepey.pdf>.

Thomas, J.B., Bodnar, R.J., Shimizu, N., Chesner, C.A., 2003, "Melt Inclusions in Zircon." Reviews in Mineralogy and Geochemistry v. 53, ch. 3 p. 63-87.

Ver Straeten, C.A., Griffing, D.H., Brett, C.E., 1994, "The lower part of the Middle Devonian Marcellus "Shale", central to western New York State: stratigraphy and depositional history," New York State Geological Association, 66th Annual Meeting Field Trip Guidebook. p. 271-321.

Ver Straeten, C.A., 2004, "K-bentonites, volcanic ash preservation, and implications for Early to Middle Devonian volcanism in the Acadian Orogen, eastern North America" Geological Society of America Bulletin, v. 116, no. 3-4, p. 474-489.

Ver Straeten, C.A., 2007, "Basinwide stratigraphic synthesis and sequence stratigraphy, upper Pragian, Emsian and Eifelian stages (Lower to Middle Devonian), Appalachian Basin, in R. Becker, and W. Kirchgasser, eds., Devonian events and correlations" Geological Society Special Publications, p. 39-81.

Ver Straeten, C.A., 2010, "Lessons from the Foreland Basin: Northern Appalachian basin perspectives on the Acadian Orogeny”, The Geological Society of America, p. 251-282.

Werne, J., B. Sageman, T., Lyons, D., Hollander, 2002, “An integrated assessment of a "type euxinic" deposit; evidence for multiple controls on black shale deposition in the Middle Devonian Oatka Creek Formation" American Journal of Science, v. 302, p. 110-143. 


\section{APPENDIX 1}

\section{ASH DESCRIPTIONS AND CORE PICTURES}

ECA Coldstream \#1

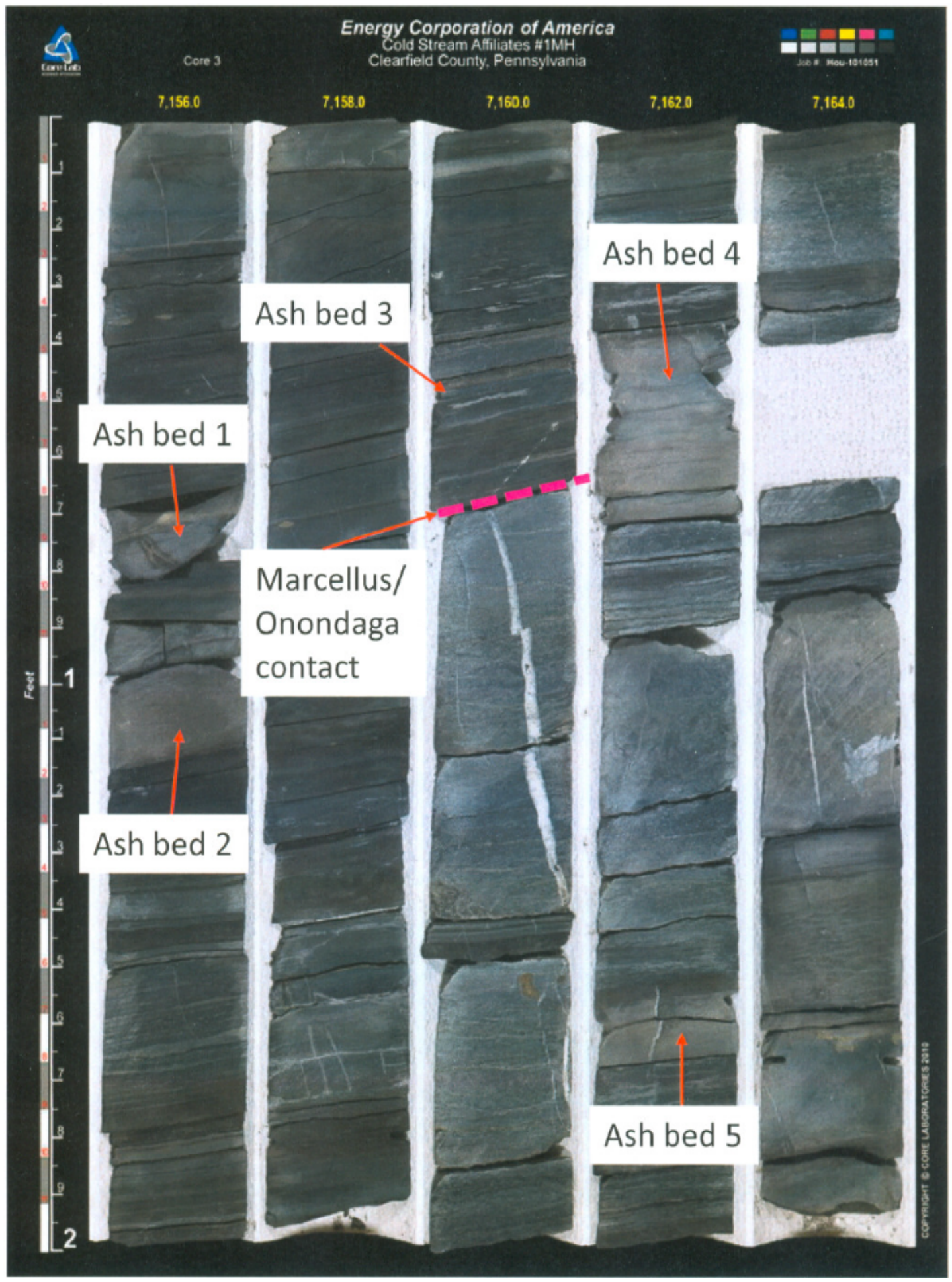

Description on page 68 


\section{ECA Coldstream Affiliates \#1MH}

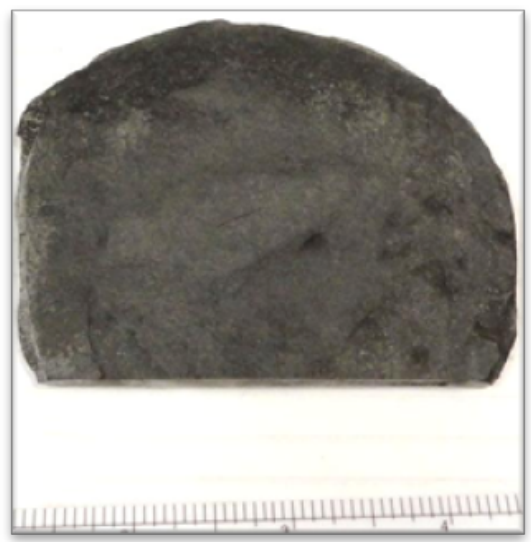

Ash Bed 1

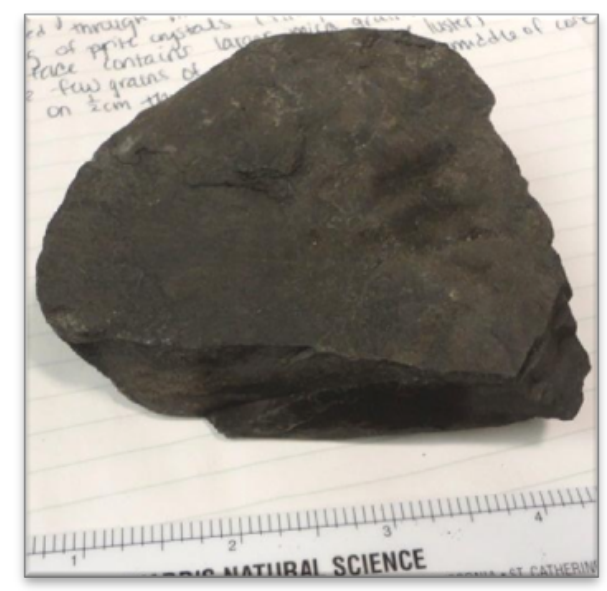

Ash Bed 2

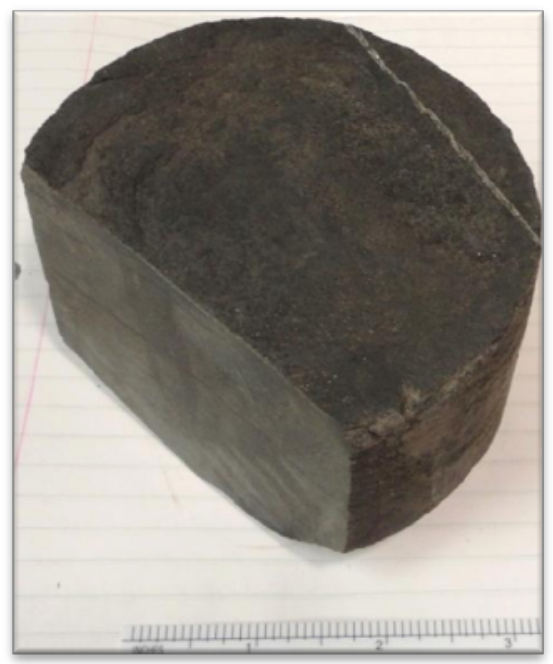

Ash Bed 3

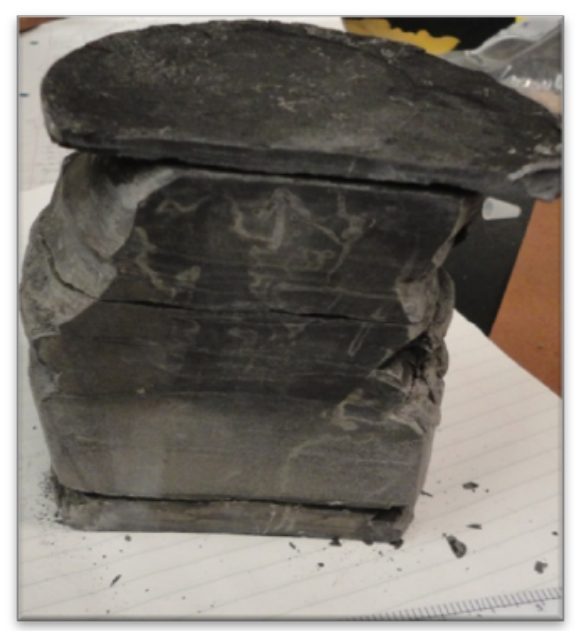

Ash Bed 4

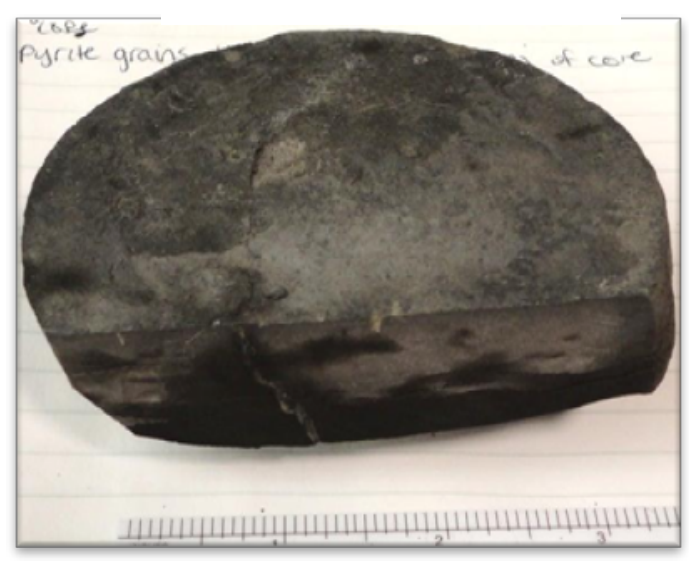

Ash Bed 5 


\title{
ECA Coldstream Affiliates \#1MH
}

\section{Clearfield County, PA}

\section{ASH BED 1}

Core depth of 7156.7 feet

Log depth of 7142.4 feet

Approximately $3 \mathrm{~cm}$ thick and 297.05 grams in weight

Dark grey, thinly laminated shale with wavy-non parallel stratification

Ash within core is $0.5 \mathrm{~cm}$ thick with very fine to fine grained white mica and fine grained pyrite crystals

Ash exhibits fining upward graded bedding of well sorted pyrite crystals

Top surface contains larger sheet-like mica crystals

No fossils or bioturbation

\begin{abstract}
ASH BED 2
Core depth of 7157.2 feet

Log depth of 7142.9 feet

Approximately $5 \mathrm{~cm}$ thick

Shale is grey to dark grey, thinly laminated with wavy non-parallel stratification

$1 \mathrm{~mm}$ calcite vein fracture along the length of the core

Ash displays fining upward graded bedding with graded white mica crystals

Bottom surface of core has larger medium grained, angular and poorly sorted mica crystals

No pyrite

No fossils or bioturbation
\end{abstract}

\author{
ASH BED 3 \\ core depth of 7160.5 feet \\ Log depth of 7146.17 feet \\ Approximately $6 \mathrm{~mm}$ thick and 108.65 grams in weight \\ Shale is dark grey, thinly laminted, wavy nonparallel stratification, more fissile than Ash 1 and 2 \\ Ash contains more sparse mica grains than other Cold Stream ashes \\ White mica is fine to medium grained with rounded crystals \\ Fossil found with microscope on edge of core above the ash layer
}

\author{
ASH BED 4 \\ core depth of 7162.4 \\ Log depth of 7148.11 feet \\ Total $10 \mathrm{~cm}$ thick separated in four pieces \\ Shale is light grey, thinly laminated, fissile/platey \\ Bottom $4 \mathrm{~cm}$ contain high concentrations of pyrite and mica \\ White mica poorly sorted, medium to coarse grained dispersed throughout bentonite
}


Bottom $4 \mathrm{~cm}$ display graded bedding, fining upward Fossils are abundant on two surfaces

\section{ASH BED 5}

core depth 7163.5 feet

Log depth 7149.3 feet

Approximately $2.5 \mathrm{~cm}$ thick

Shale is grey to dark grey, thinly laminated, wavy parallel to non-parallel stratification

Calcite vein fracture through the center of the core

Ash contains mica visible on the top and bottom surfaces

Bottom surface of ash contains higher concentration of white mica, ranging from fine to coarse grained, well sorted

Fining upward graded bedding from the base to the top of this core

Pyrite grains dispersed on outer edges of core

Fossils found on top of the ash layer containing pyritized brachiopods up to $3 \mathrm{~mm}$ in length 


\section{EQT 511391}

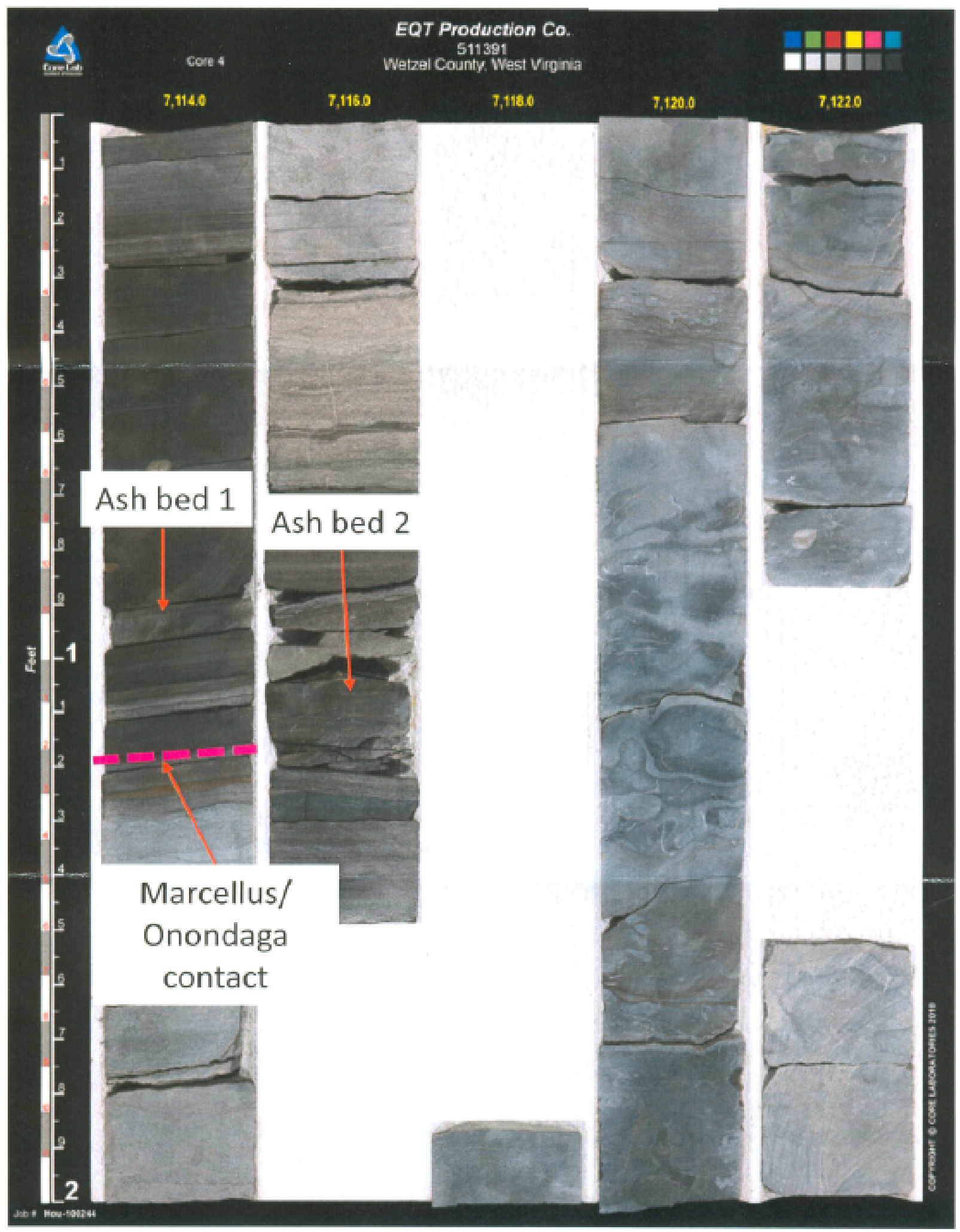

Description on page 72 
EQT Wetzel County, WV

EQT 511391

\section{ASH BED 1}

Core depth 7114.9 feet

$1.2 \mathrm{~cm}$ thick

Medium to light grey, wavy and parallel continuous stratification in the shale

White mica is found on all surfaces of the core

At the base of the fining upward graded bedding, the white mica is fine to medium grained

Pyrite grains are very fine grained and dispersed throughout the core

$2.5 \mathrm{~cm}$ long calcite vein

\section{ASH BED 2}

Core depth 7117.05-7117.20 feet

Measured total $6 \mathrm{~cm}$ thick but broken in several pieces.

Shale displays wavy, nonparallel stratification

Thin wavy nonparallel beds of pyrite, grains very fine grained and moderately sorted

Pyrite nodules on flat cut surface of core about 2-3 $\mathrm{mm}$ in length and are discontinuous between beds

Graded bedding throughout ash with white mica and pyrite fining upward

Base of the core is shale with abrupt contact with ash

Fracture surfaces in core have slickenlines 


\section{PDC Goff \#55}

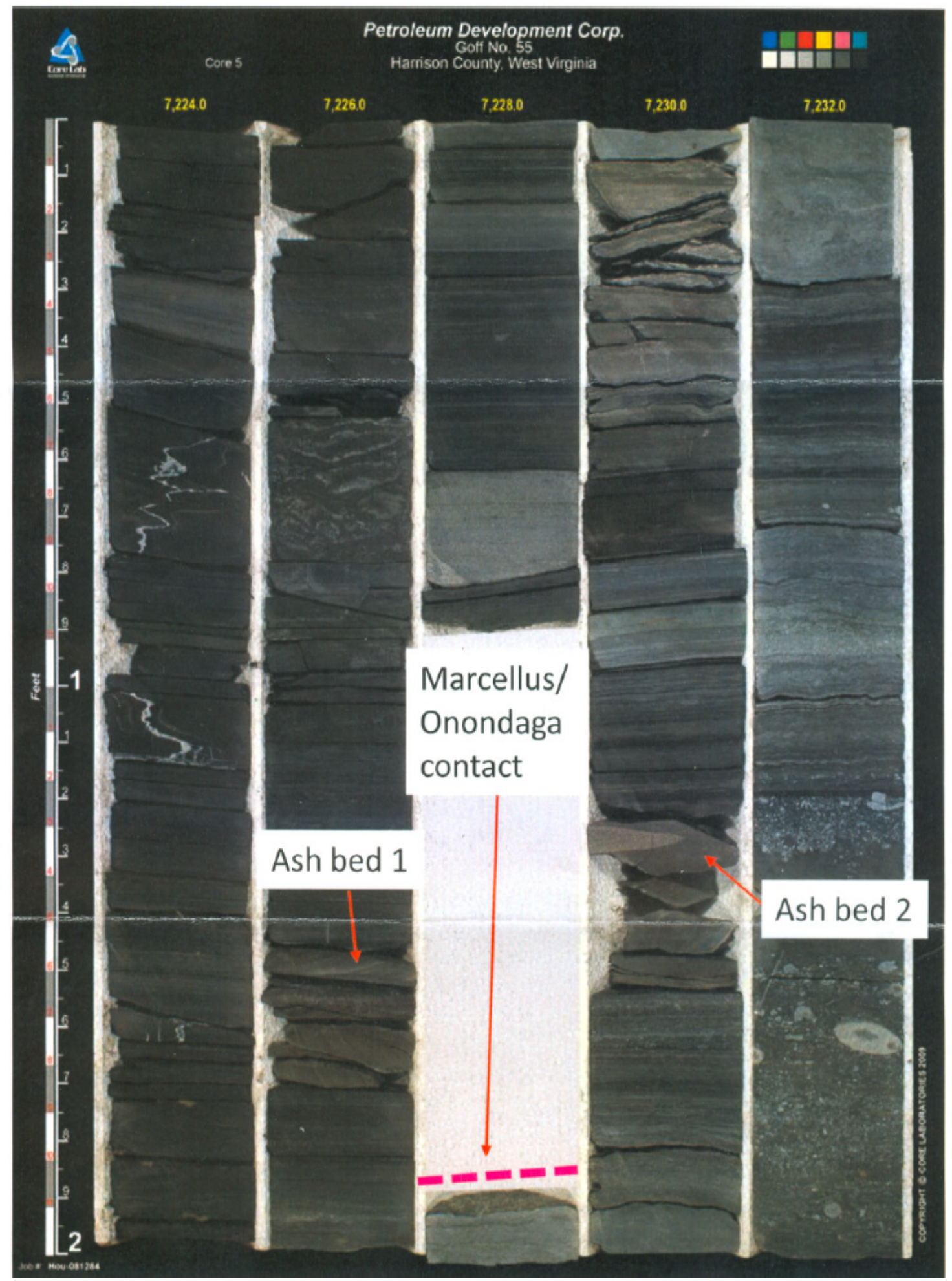

Description on page 74 


\title{
PDC Harrison County, WV \\ PDC Goff \#55
}

\author{
ASH BED 1 \\ Core depth 7227.45 feet \\ Log depth 7230.45 feet \\ Very disorganized, broken into 15 pieces or more, core not properly in depth order \\ Bedding stratification is wavy discontinuous nonparallel \\ Shale is light grey, flakey and fissile \\ Mica grains are not visible on surfaces of most pieces except a few \\ Few pieces have pyrite grains and small pyrite nodules $2-3 \mathrm{~mm}$ length \\ Only one fragment displays graded bedding
}

\author{
ASH BED 2 \\ Core depth 7231.24 feet \\ Log depth 7234.24 feet \\ Top of ash has very small fine grained white mica \\ Graded bedding not visible, core is broken into many pieces \\ Small $2.2 \mathrm{~cm}$ thick core piece has $1.5 \mathrm{~cm}$ thick pyrite bed \\ A few smaller pieces have white mica mixed within the ash \\ Most of this core is disturbed and looks highly altered. Difficult core analysis
}




\section{PDC Armstrong \#1}

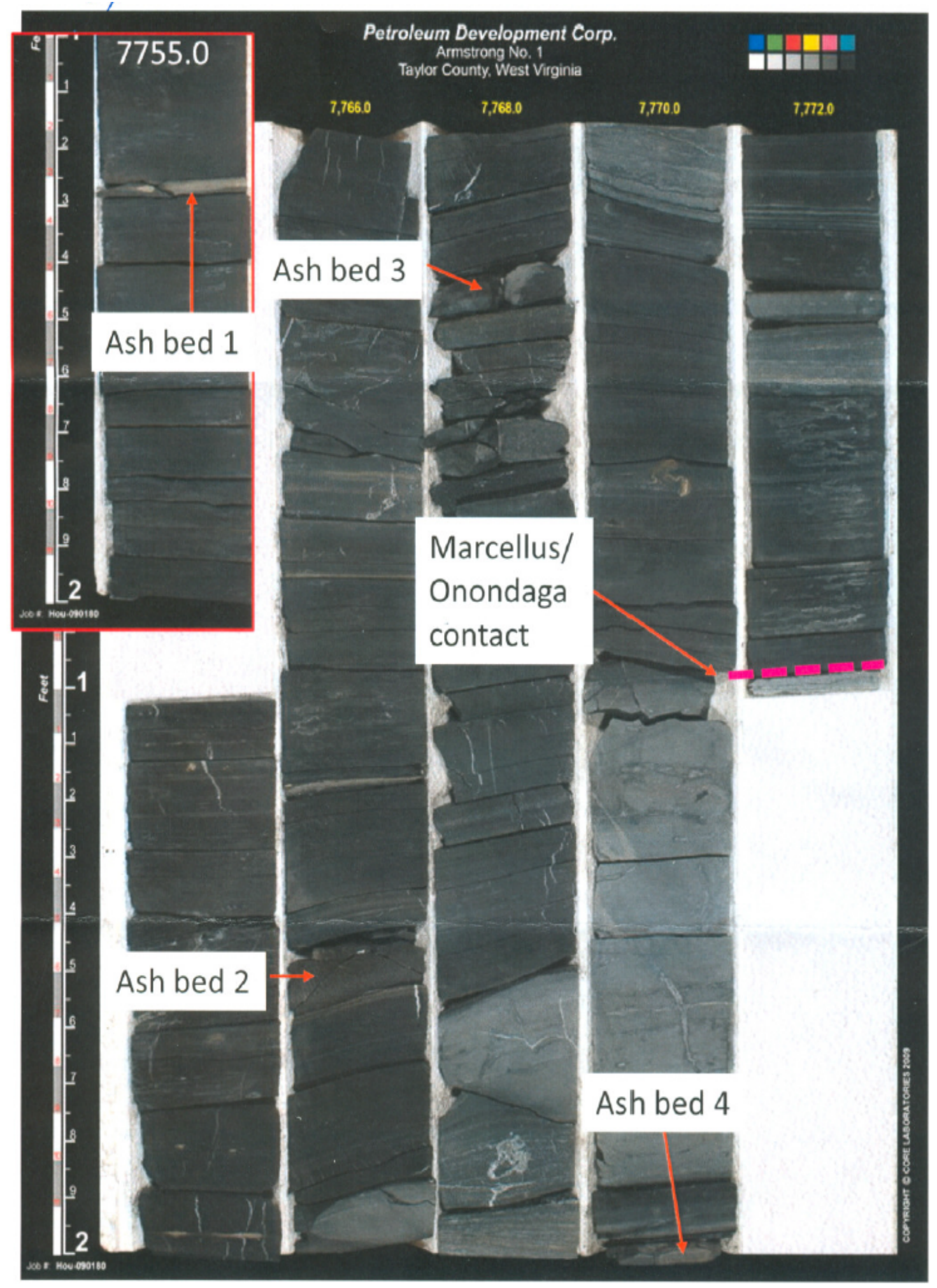

Description on page 77 


\section{PDC Armstrong \#1}

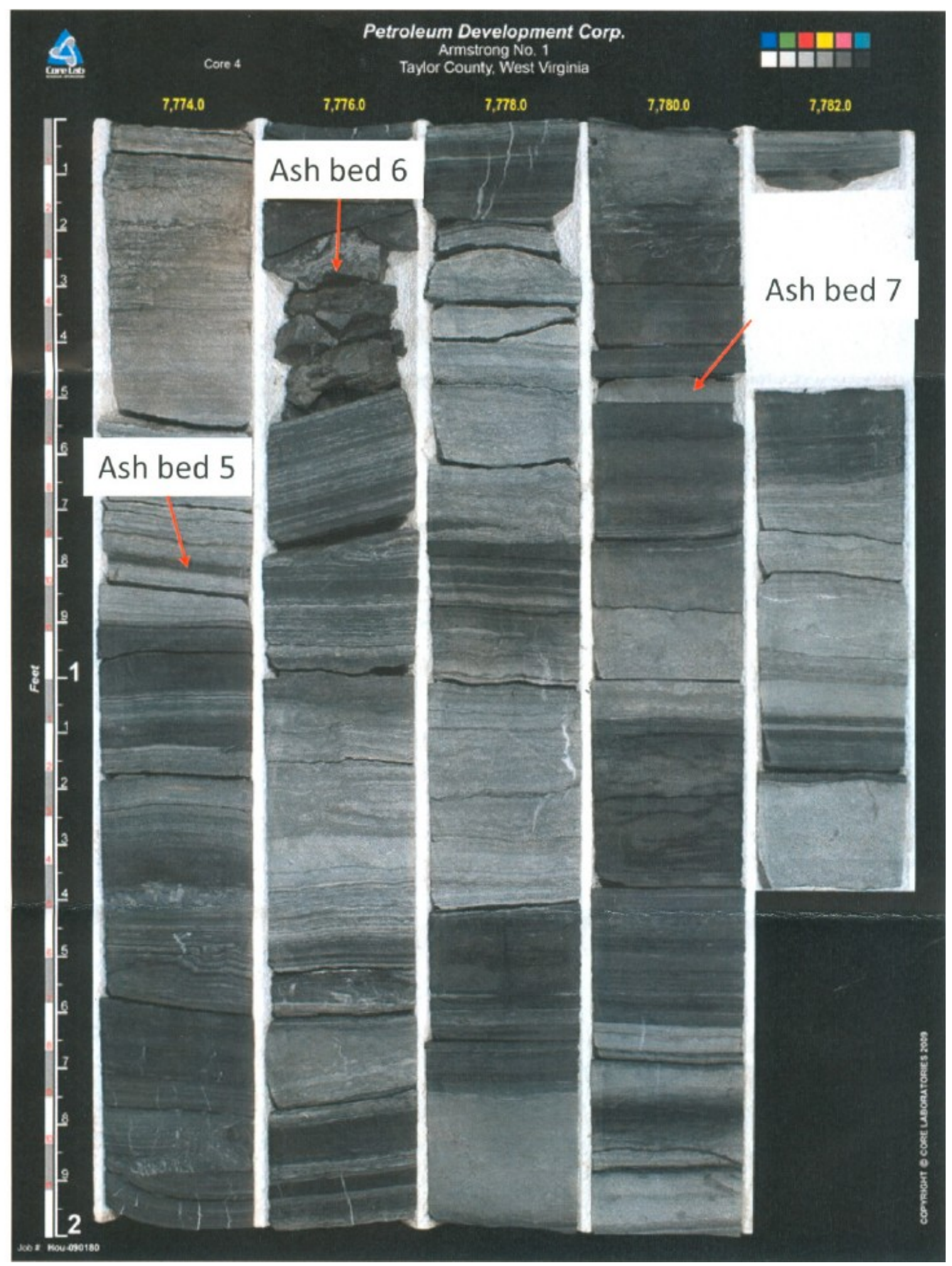

Description on page 76 


\section{PDC Taylor County, WV}

\section{PDC Armstrong \#1}

\section{ASH BED 1}

Core depth 7755.27 feet

Log depth 7761.27 feet

Very thin $-0.6 \mathrm{~cm}$

Shale is very fine grained, platey

Parallel laminations but discontinuous stratification

Pyrite grains are very fine grained and evenly dispersed throughout core

Chalcopyrite nodules

Graded bedding of thin pyrite $2 \mathrm{~mm}$ thick

White mica less frequently found in core

Bottom of ash has very fine grained white mica

\section{ASH BED 2}

Core depth 7767.45 feet

Log depth 7773.45 feet

Core is extremely broken up

Shale is medium grey, very fine grained

Wavy nonparallel stratification, fissile

Does not fizz with $\mathrm{HCl}$

Graded bedding approximately $1.1 \mathrm{~cm}$ thick

White mica evenly distributed, medium to fine grained

No pyrite

Slickenlines on fractures

\section{ASH BED 3}

Core depth 7768.28 feet

Log depth 7774.28 feet

Broken into $30+$ pieces

Graded bedding visible on some broken surfaces

White mica medium grained moderately well sorted

Shale is light grey, wavy, nonparallel stratification

No pyrite visible

All fragments except for 3 large pieces do not contain white mica

Calcite veins through many pieces

Slickenlines on majority of pieces

Scratch test shows light brown powder with light grey waxy surface scratch

Fragments seem highly altered 


\begin{abstract}
ASH BED 4
Core depth 7771.95

Log depth 7780.45

Broken into 10 pieces

Graded bedding $1 \mathrm{~cm}$ thick

Pyrite grains are very fine grained and also exhibit graded bedding characteristics

Mica is difficult to see, looks evenly mixed with pyrite, except one surface exposes medium grained white mica

Shale is flakey and fissile

White mica only visible at the base of ash

Calcite veins/slickenlines visible on most pieces
\end{abstract}

\title{
ASH BED 5
}

Core depth 7774.78 feet

Log depth 7783.28 feet

Very thin, broken into $15+$ pieces each $\sim 1 \mathrm{~cm}$ wide

Thin calcite veins between each bedding plane

$\mathrm{HCl}$ fizzes on bedding but not on shale

Graded bedding not visible, core is too thin

White mica exists within broken pieces, very fine to medium grained, poorly sorted Surrounding shale is grey, fissile

Not much visible other than sparse mica on surfaces of 2 pieces

\section{ASH BED 6}

Core depth 7776.25 feet

Log depth 7784.75 feet

Broken into $100+$ pieces, only a few larger pieces about $4 \mathrm{~cm}$ long

Pieces much more sharp and contains rough texture than other core

Fissile/platey, wavy nonparallel stratification

Calcite veins $1 \mathrm{~mm}$ thick on three pieces

Fine grained pyrite dispersed throughout most pieces

Only two large pieces of ash contain large mica crystals about $2 \mathrm{~mm}$ thick bedding

\section{ASH BED 7}

Core depth 7780.46 feet

Log depth 7786.46 feet

Great example of ash bed, very diagnostic features

Medium to coarse grained white mica covering all surfaces

Small calcite veins on bedding

$2 \mathrm{~mm}$ brachiopod

Graded bedding $1.2 \mathrm{~cm}$ thick

Fine grained pyrite mixed within white mica

Shale is light grey, scratches grey with light brown powder 


\section{ECA St. Whipkey \#1}

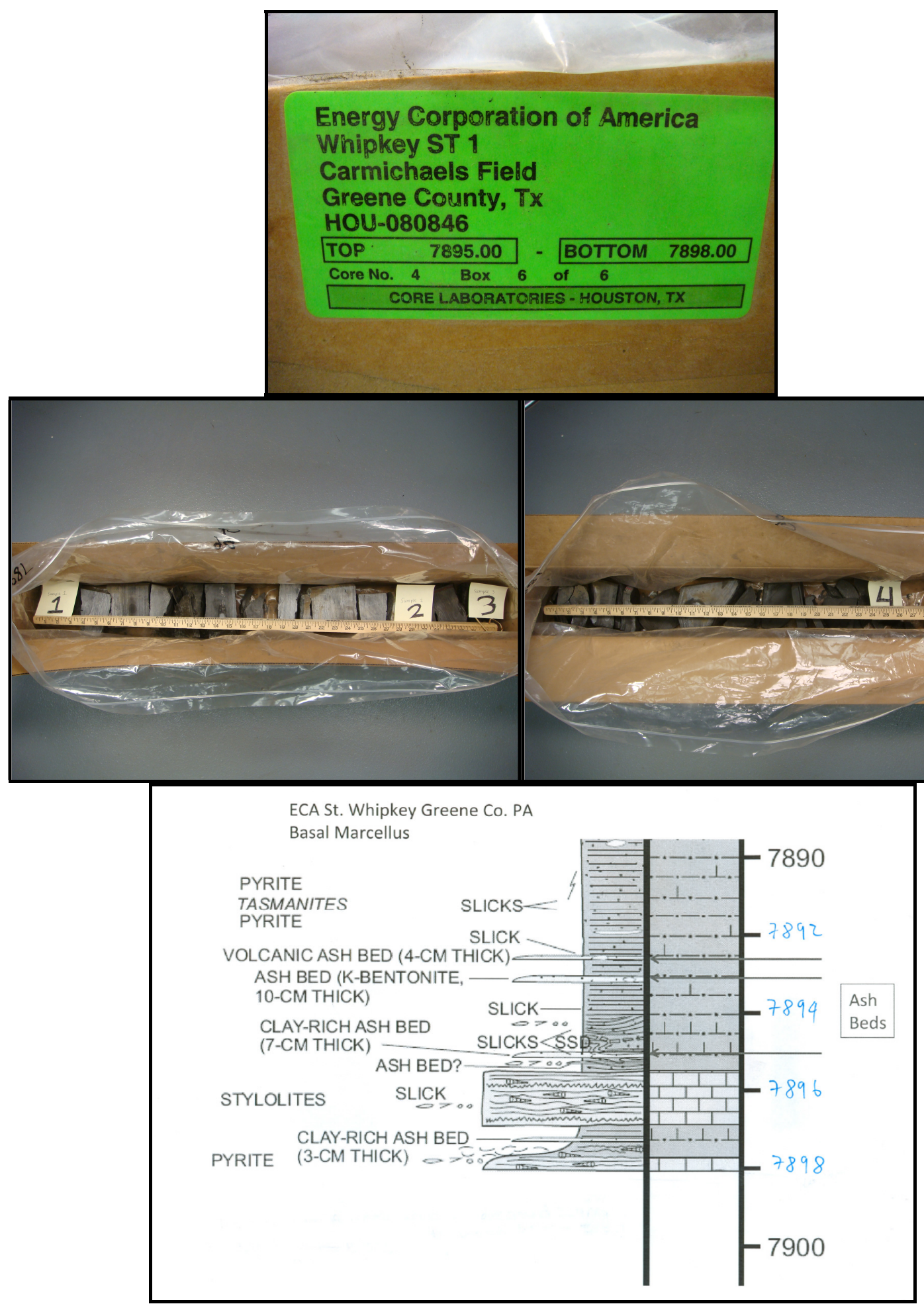

Description on page 80 


\title{
ECA Greene County, PA
}

\section{ECA St. Whipkey \#1}

\begin{abstract}
ASH BED 1
Core depth 7893.1 feet

Log depth 7884.1 feet

Dark grey shale, platey/fissile with parallel continuous stratification

$0.5 \mathrm{~cm}$ thick pyrite bed in middle of the core

Main ash located on the bottom of the core, thin about 2-3 mm thick

Mica grains are fine to medium grained and moderately sorted

No pyrite on bottom surface of the ash, but is distributed only in the middle of the core Ash bed seems graded, but too thin to for confidence

Scratch test- powder is light brown/gray, scratch is waxy
\end{abstract}

\author{
ASH BED 2 \\ Core depth 7893.6 feet \\ Log depth 7884.6 feet \\ Shale is light to medium grey, wavy nonparallel stratification \\ White mica found dispersed within graded bedding \\ Mica is extremely abundant and visible do to coarse grains \\ 2 large pyrite nodules, very fine grained pyrite with no mica in nodules \\ Top of core is dark very fine grained shale then grades to pyrite lenses \\ Base of ash contains coarse mica grains \\ Slickenlines on all fractures
}

\section{ASH BED 4}

Core depth 7897.5 feet

Log depth 7888.5 feet

$2 \mathrm{~cm}$ thick

Shale is medium to light grey, wavy nonparallel stratification

Graded bedding not clearly visible but white mica found on all broken surfaces

Pyrite not visible within this ash bed

No fizz with HCL

Slickenlines on all surfaces, difficult to see clear ash 
Enerplus Winner 4-8
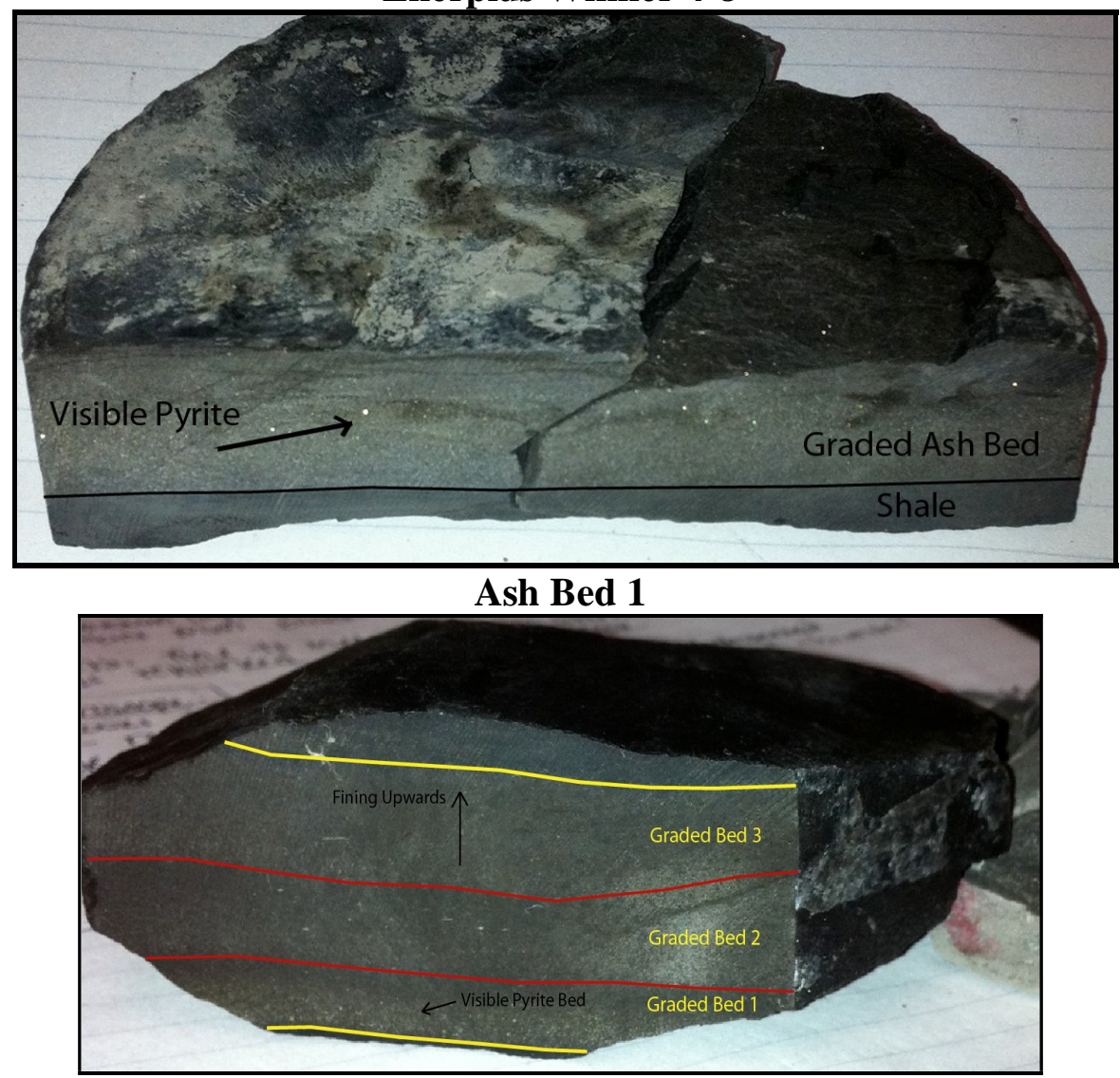

Ash Bed 3

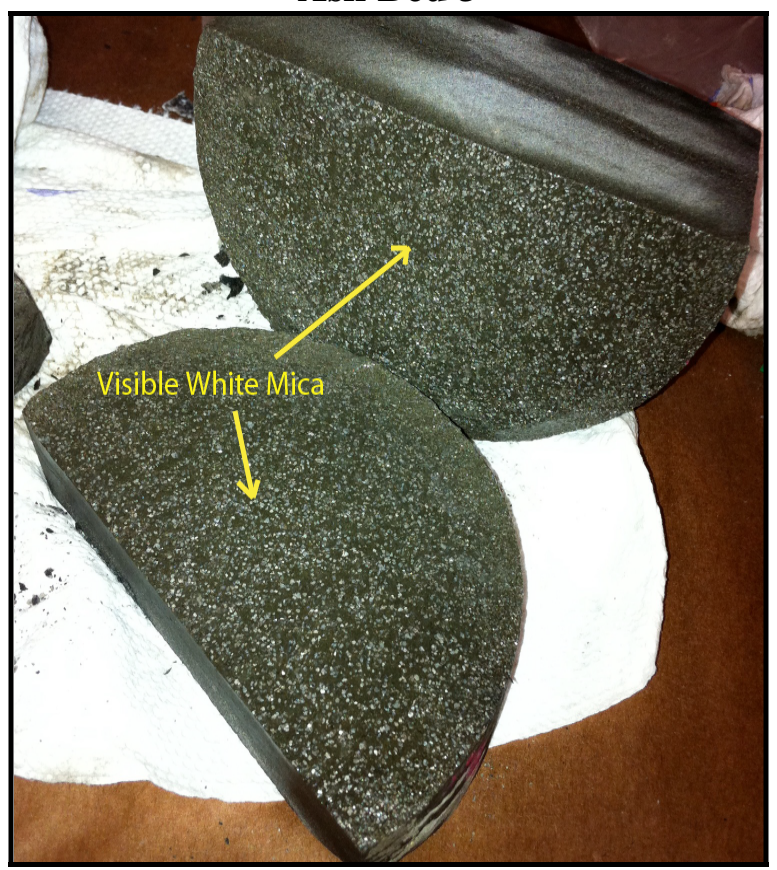

Ash Bed 4

Description on page 82 


\title{
Enerplus Clinton County, PA \\ Winner 4-8 Pilot Hole
}

\author{
ASH BED 1 \\ Core depth 8023.5 feet \\ Log depth 8030.5 feet \\ $2.25 \mathrm{~cm}$ thick
}

319.295 grams

Shale is dark grey to black, very fine grained with wavy continuous bedding

Stronger core than other samples, breaks on bedding but very difficult to break

Scratch test shows waxy brown/grey, with grey light brown powder

$\mathrm{HCl}$ fizzes on broken bedding and on slickenlines

Ash bed has sharp contact with shale and grades upward, fining upward

White mica mixed with pyrite as bed grades upward

Grains of pyrite vary from very fine to coarse

Mica varies from very fine to medium grained in size, poorly sorted

More pyrite at the top of the ash than at the base

\author{
ASH BED 2 \\ Core depth 8032.6 feet \\ Log depth 8039.6 feet \\ Extremely thick for ash $\sim 8 \mathrm{~cm}$ thick \\ Broken into two pieces, $6.5 \mathrm{~cm}$ and $1.5 \mathrm{~cm}$ \\ 6 large calcite veins about $1 \mathrm{~mm}$ thick running diagonally from the top to base of core \\ Shale is $1 \mathrm{~cm}$ thick on bottom of core \\ Shale is black to dark grey \\ Three major zones of graded bedding with large pyrite nodules \\ White mica exists throughout entire ash, with very coarse poorly sorted crystals \\ Pyrite grains are fine to medium grained, not as abundant as other samples \\ Under microscope: White mica more frequent, may contain black mica- biotite? Rare to find \\ Large creamy white crystals - calcite? \\ Graded bedding is very obvious with white mica \\ Ash seems highly reworked/altered, causing ash to be dense \\ No fossils found
}

\author{
ASH BED 3 \\ Core depth 8035.4 feet \\ Log depth 8042.4 feet \\ $4 \mathrm{~cm}$ thick, broken into 10 pieces \\ Most notable feature is 4 distinct graded beds, pyrite dispersed through graded beds accentuating \\ bedding \\ Core is very hard to break, platey when broken, wavy parallel stratification
}


Top surface has no pyrite, just white mica coarse grained crystals

Shale is dark grey very fine grained

Pyrite begins $0.5 \mathrm{~cm}$ into the ash bed

All ten pieces contain fine to coarse, poorly sorted white mica, angular, more frequent than ash 1 and 2

Under microscope: Fossils found, $2 \mathrm{~mm}$ thick brachiopod, not in tact, broken pieces, tentaculoids Looks like fossil hash, organisms transported in after ash fall

Pyrite is dense at the base of the graded beds

\section{ASH BED 4}

Core depth 8041.5 feet

Log depth 8048.5 feet

$14 \mathrm{~cm}$ thick

5 major pieces, extremely dense ash

Very coarse white mica found on all ash surfaces, much different mica than previous ash

Much less pyrite than Ash 1, 2, 3

White mica well sorted with two graded beds

Shale is very fine grained, black, dark grey, with sharp contact with base of ash bed, wavy continuous stratification

Under microscope: coarse mica up to $1 \mathrm{~mm}$ diameter, can see sheets of mica

Pyrite only found on two surfaces, but very fine grained

Potential calcite and biotite crystals?

No fossils 


\section{ZIRCON AGE DATA}

\section{WHIPKEY 4}
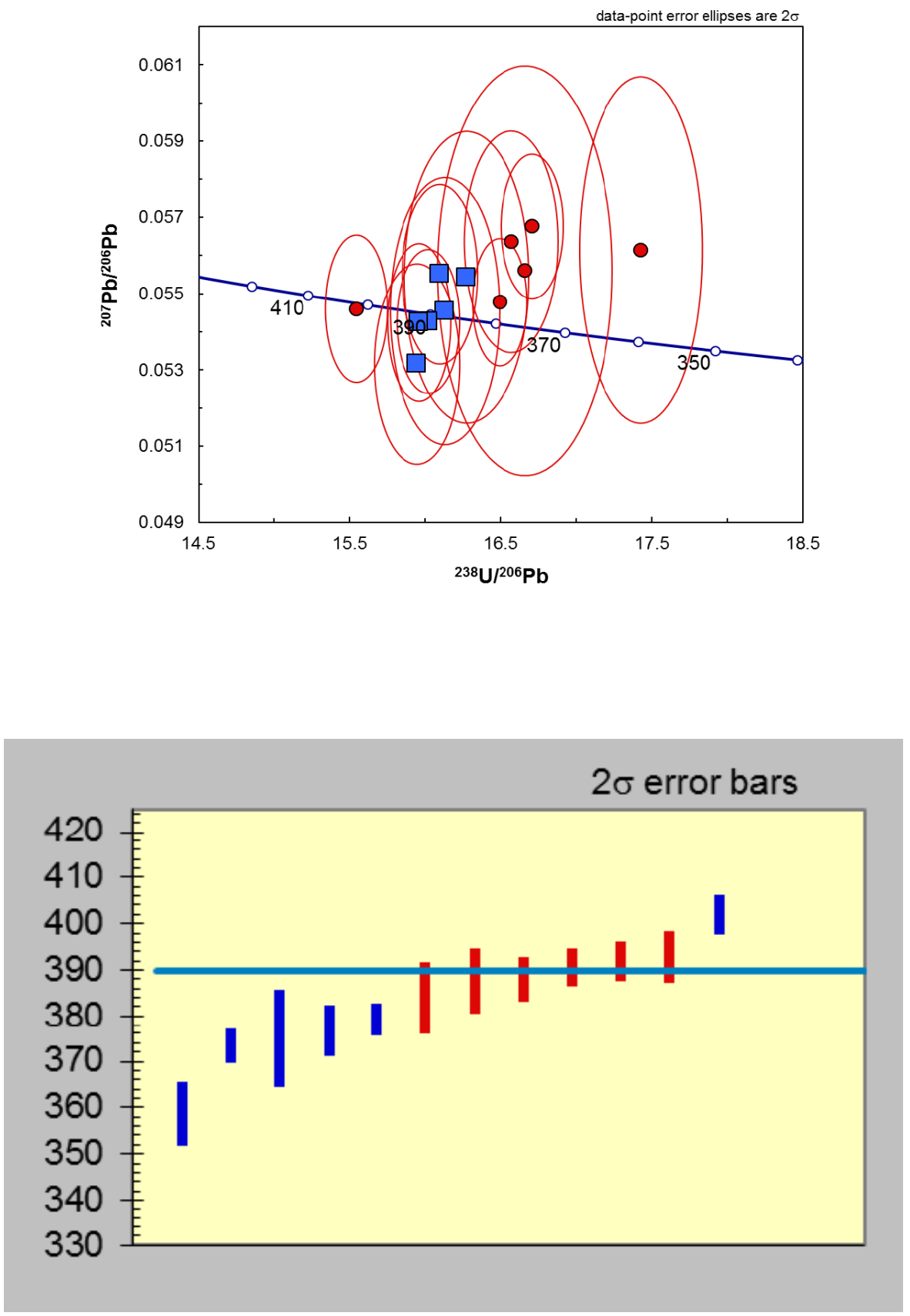


\section{GOFF 2}
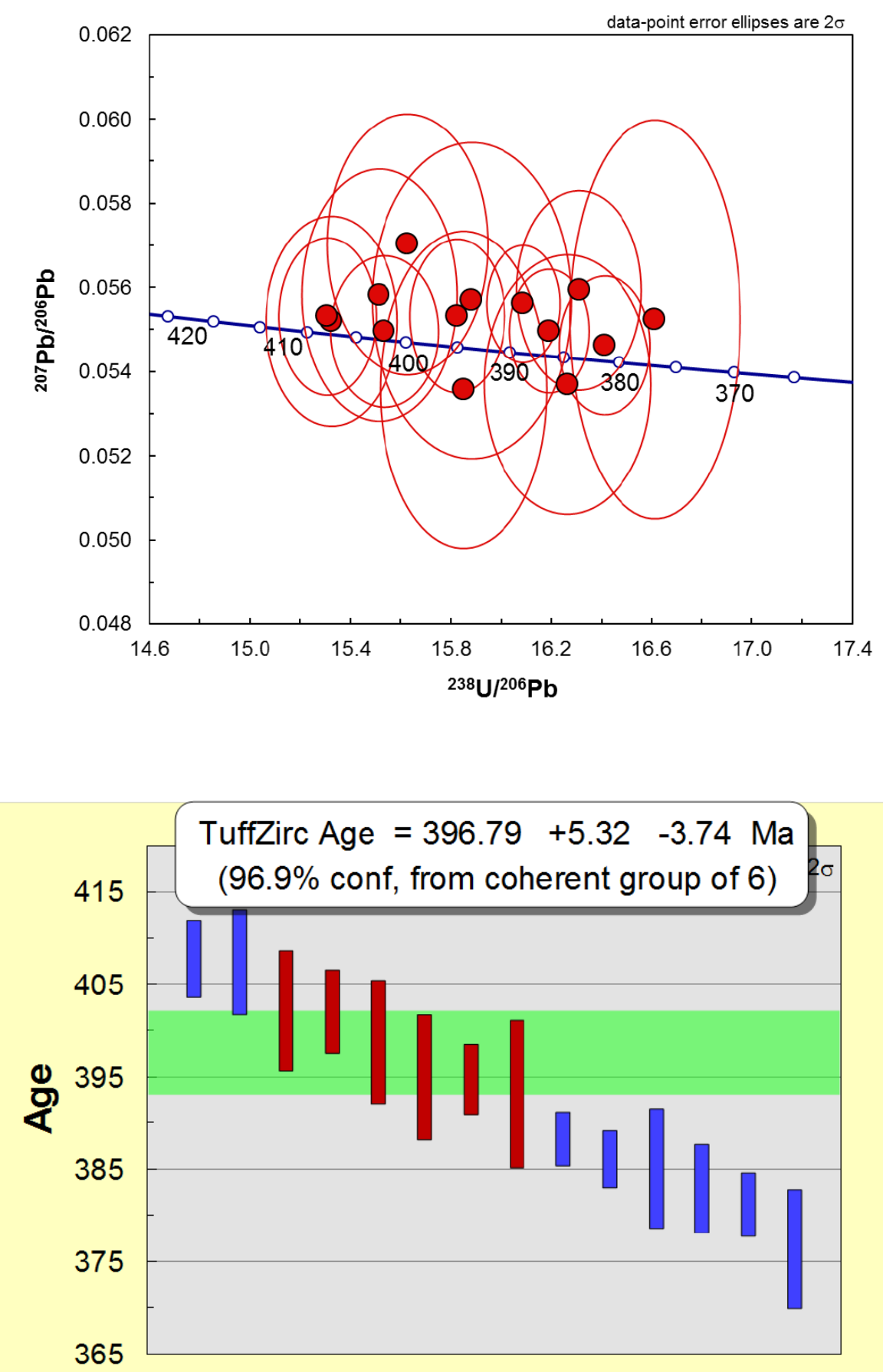
COLD 5
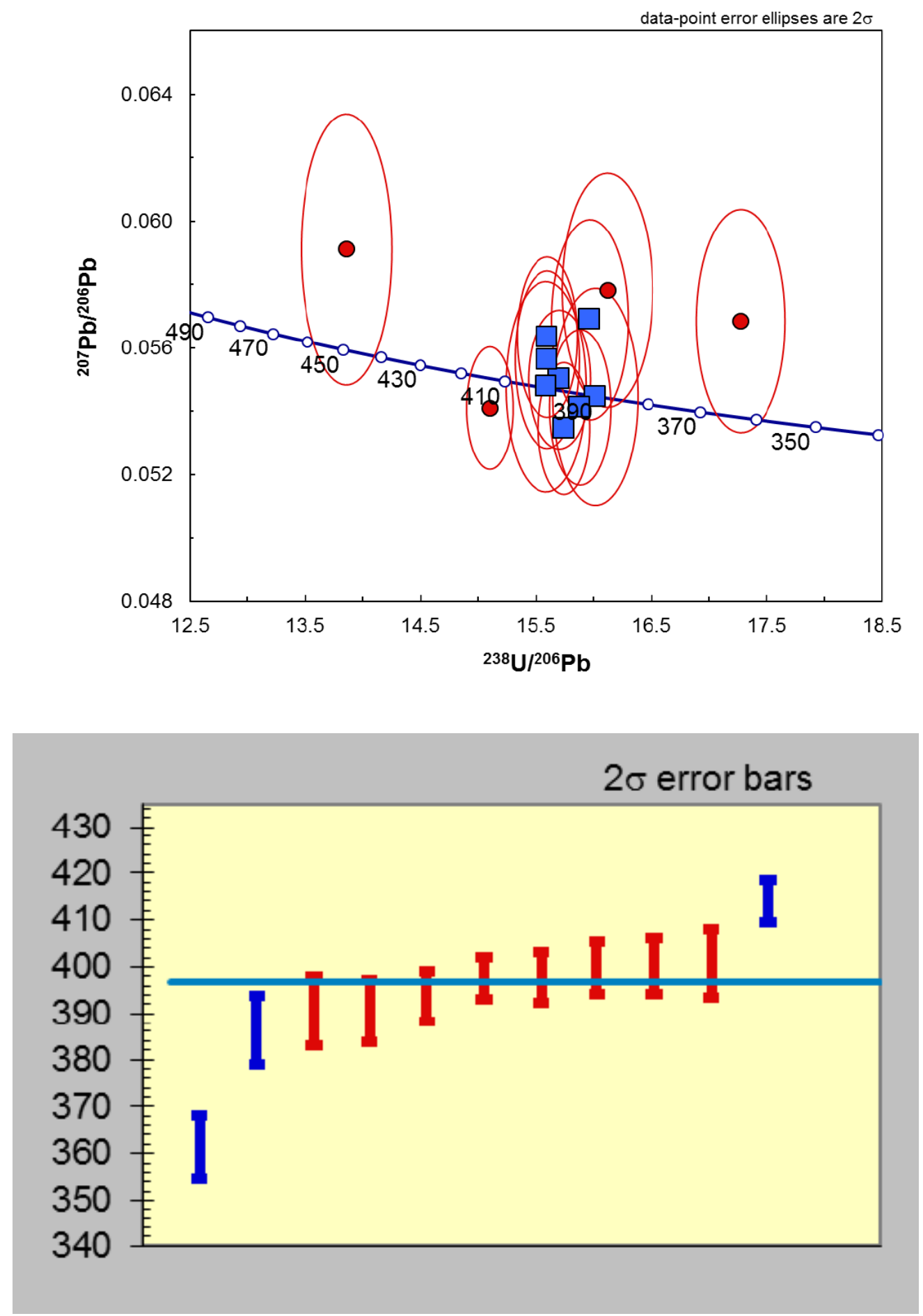


\section{COLD 1}
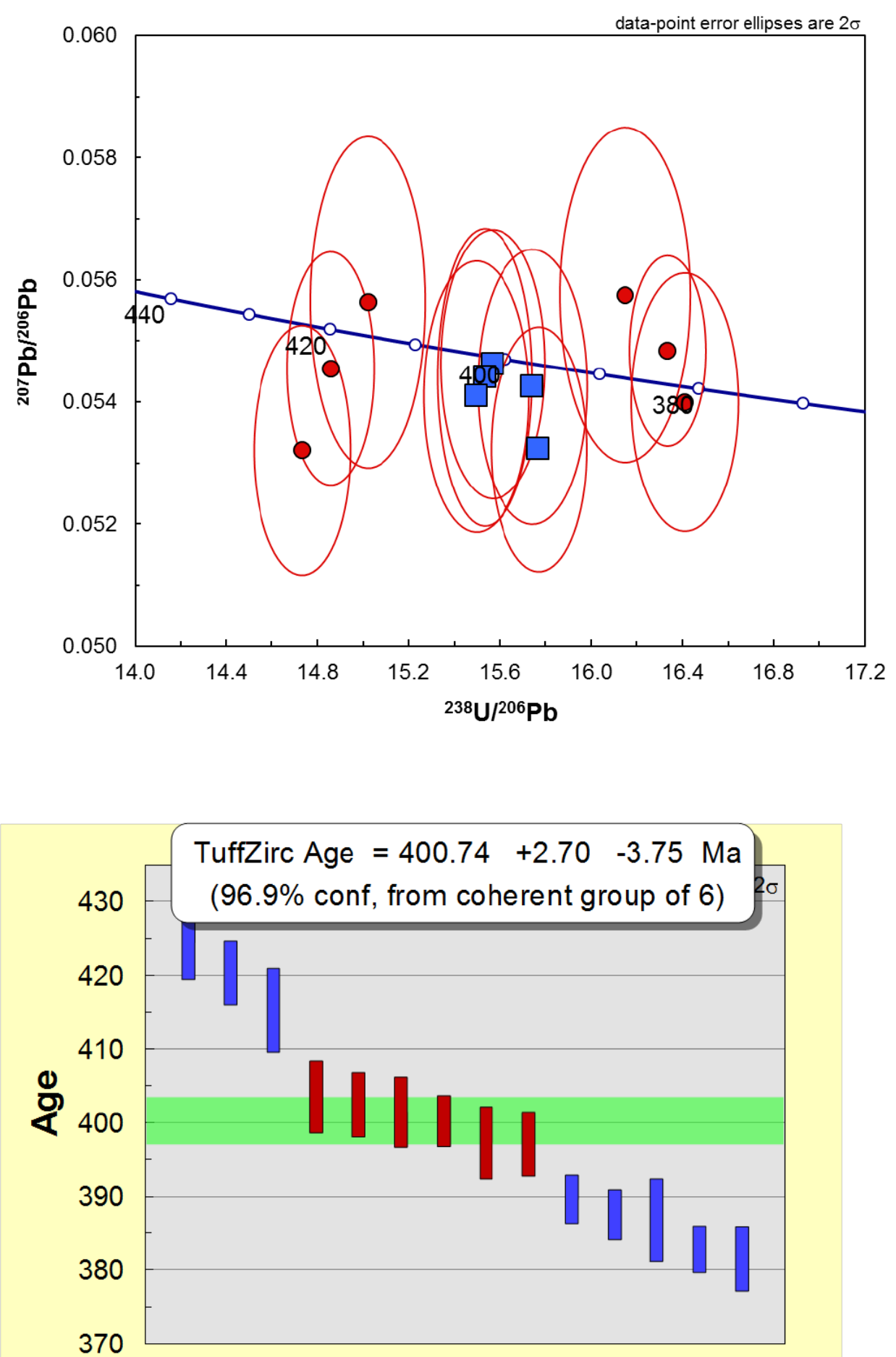


\section{GOFF 1}
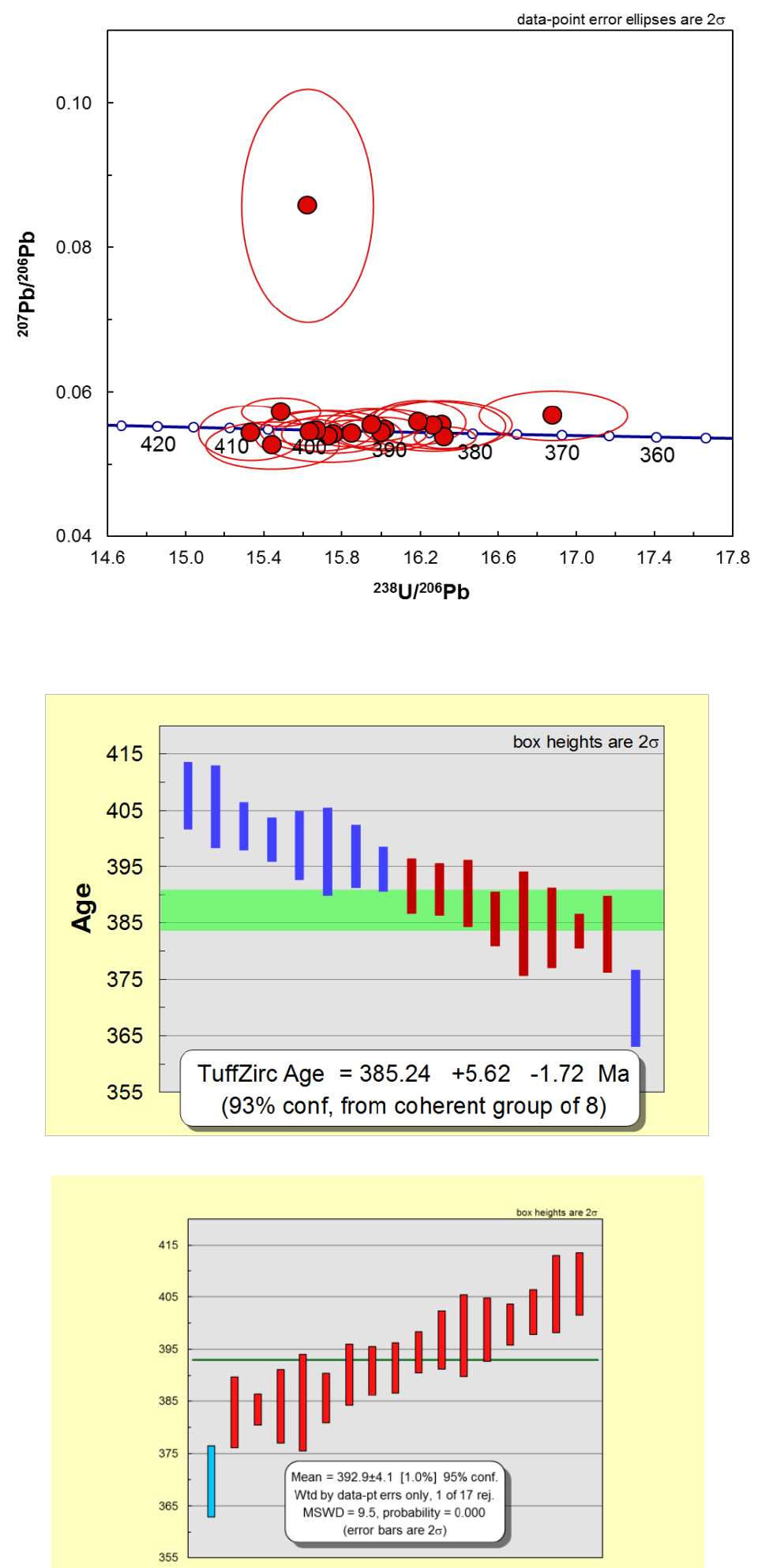


\section{WHIPKEY 2}
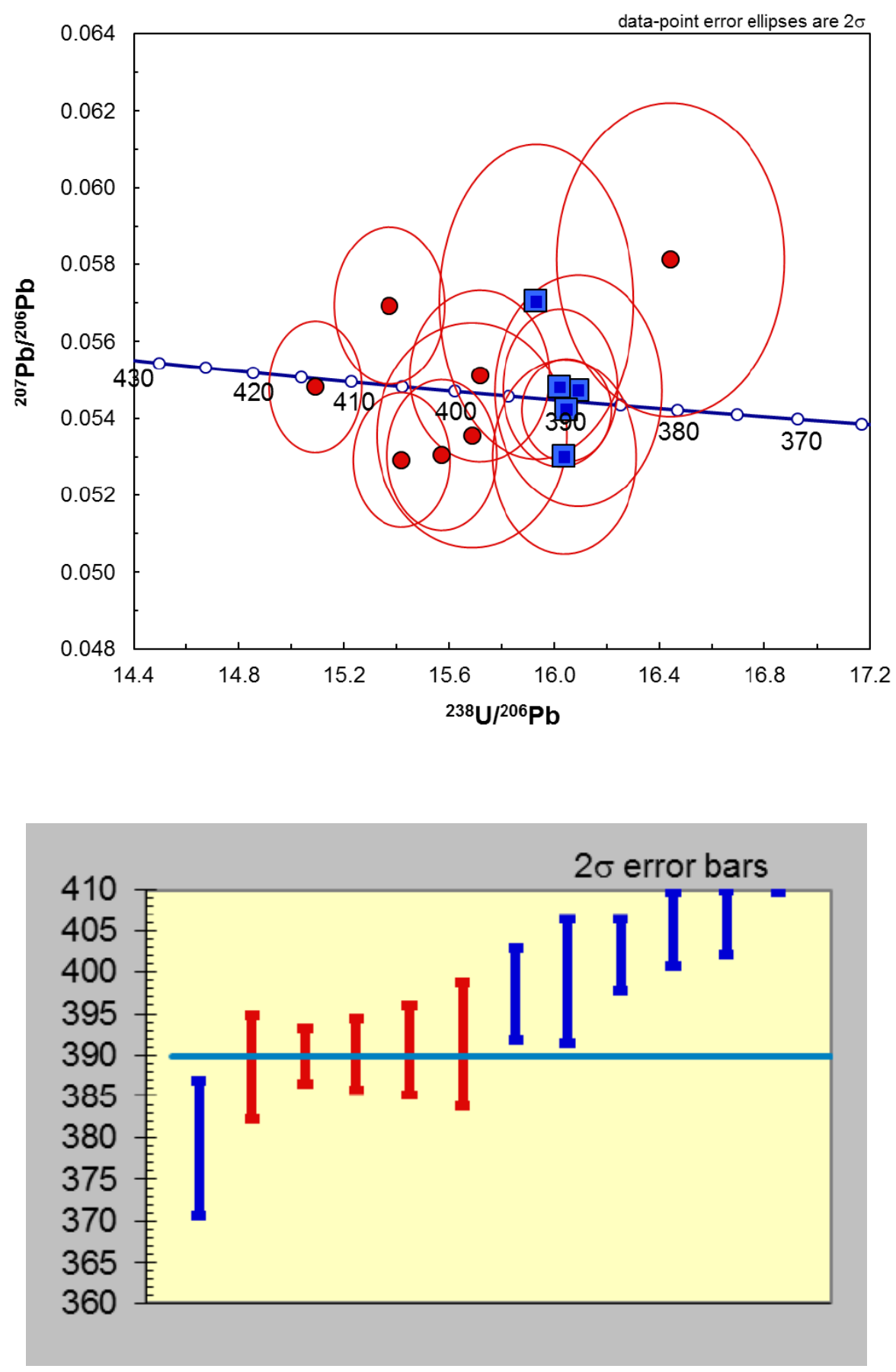


\section{EQT 1}
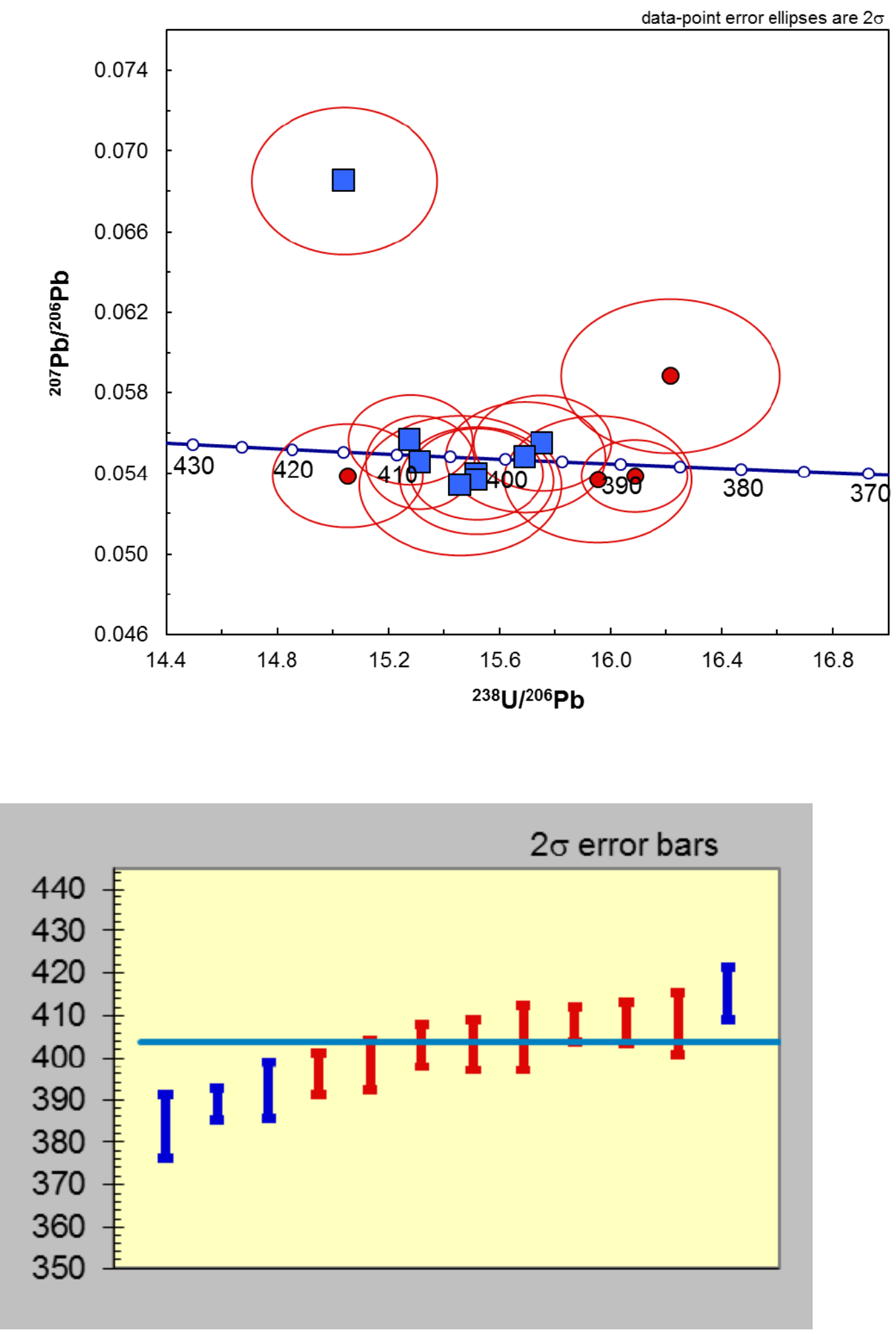


\section{EQT 2}
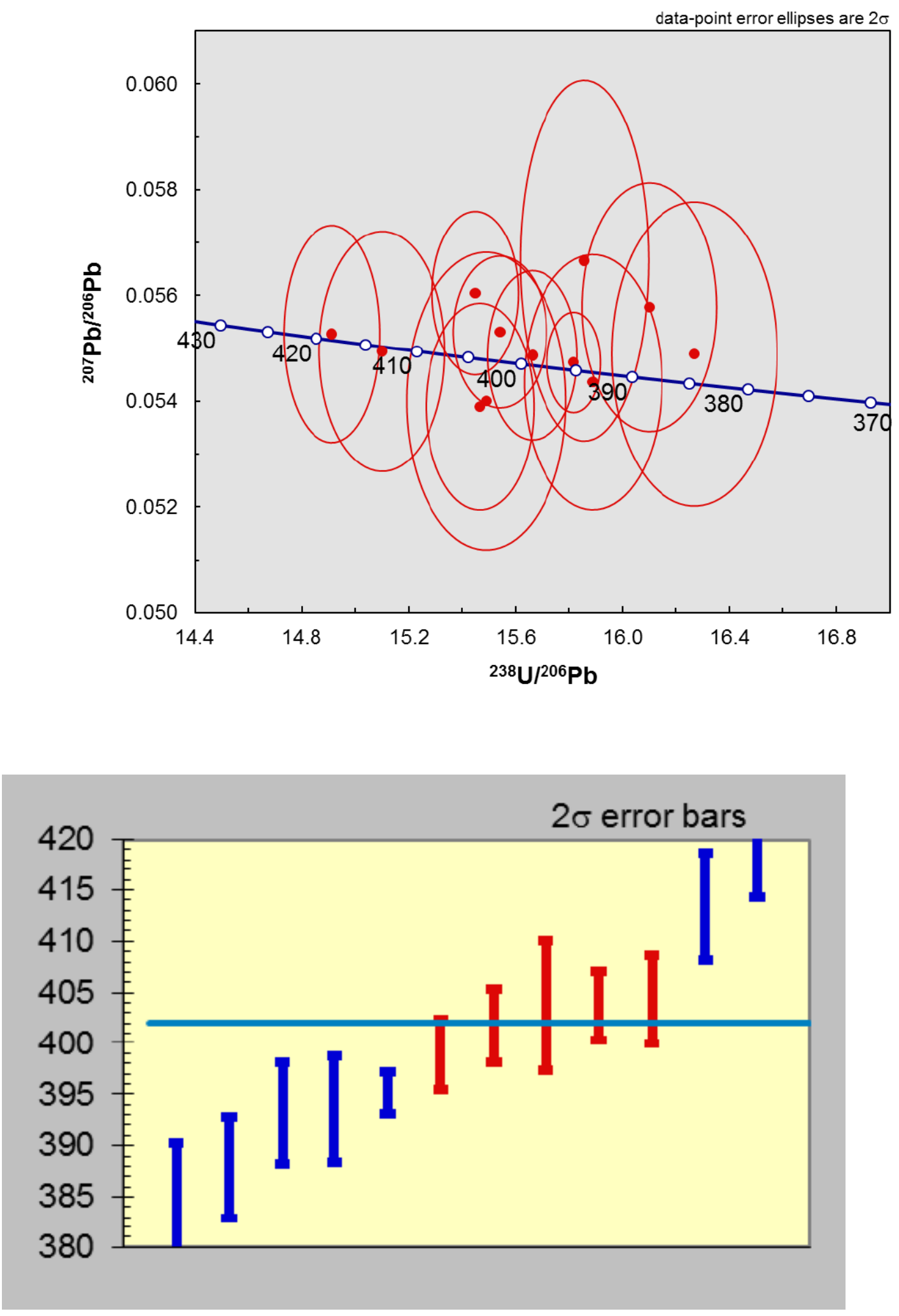


\section{ARM 1}
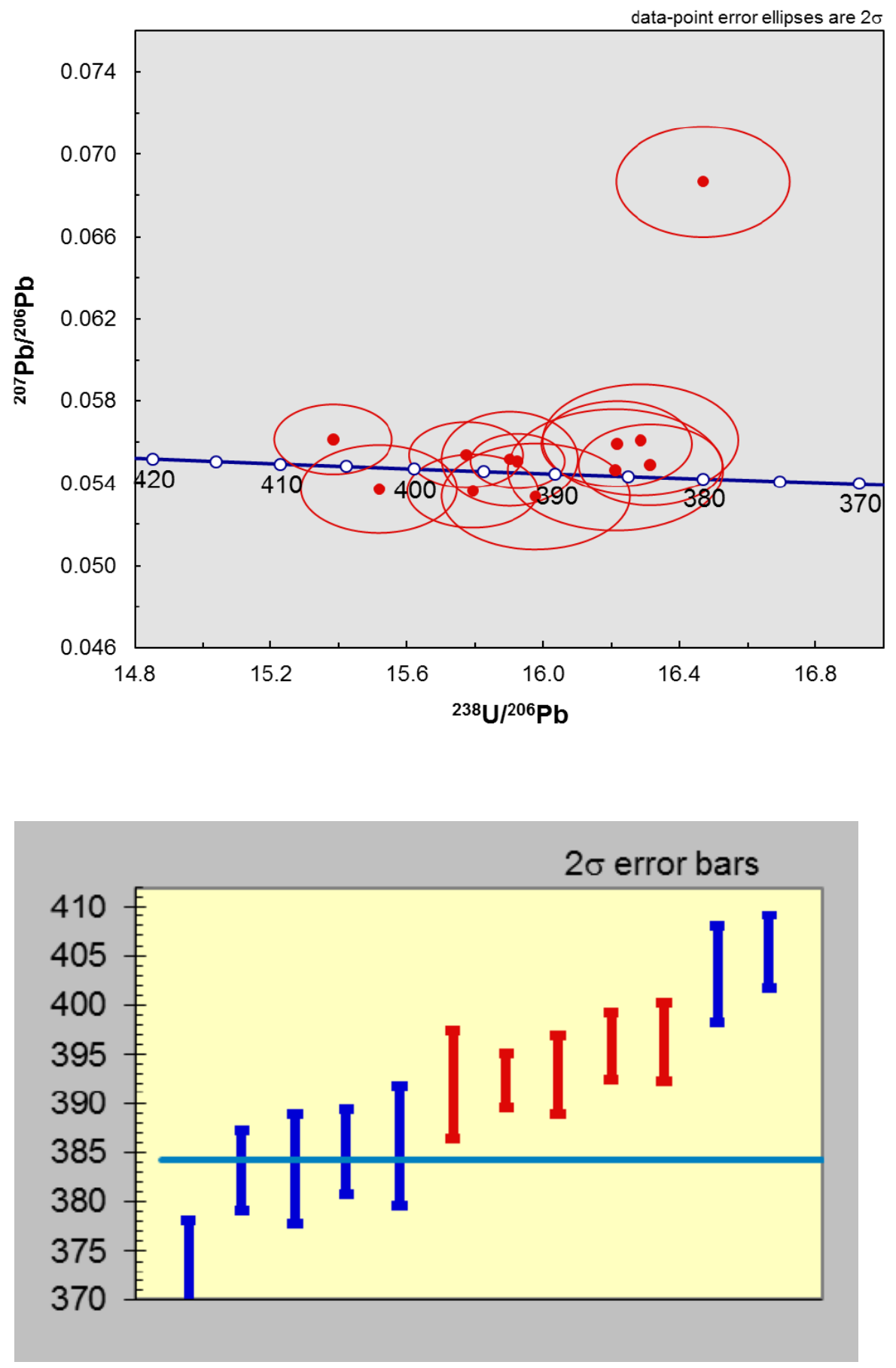
ARM 7
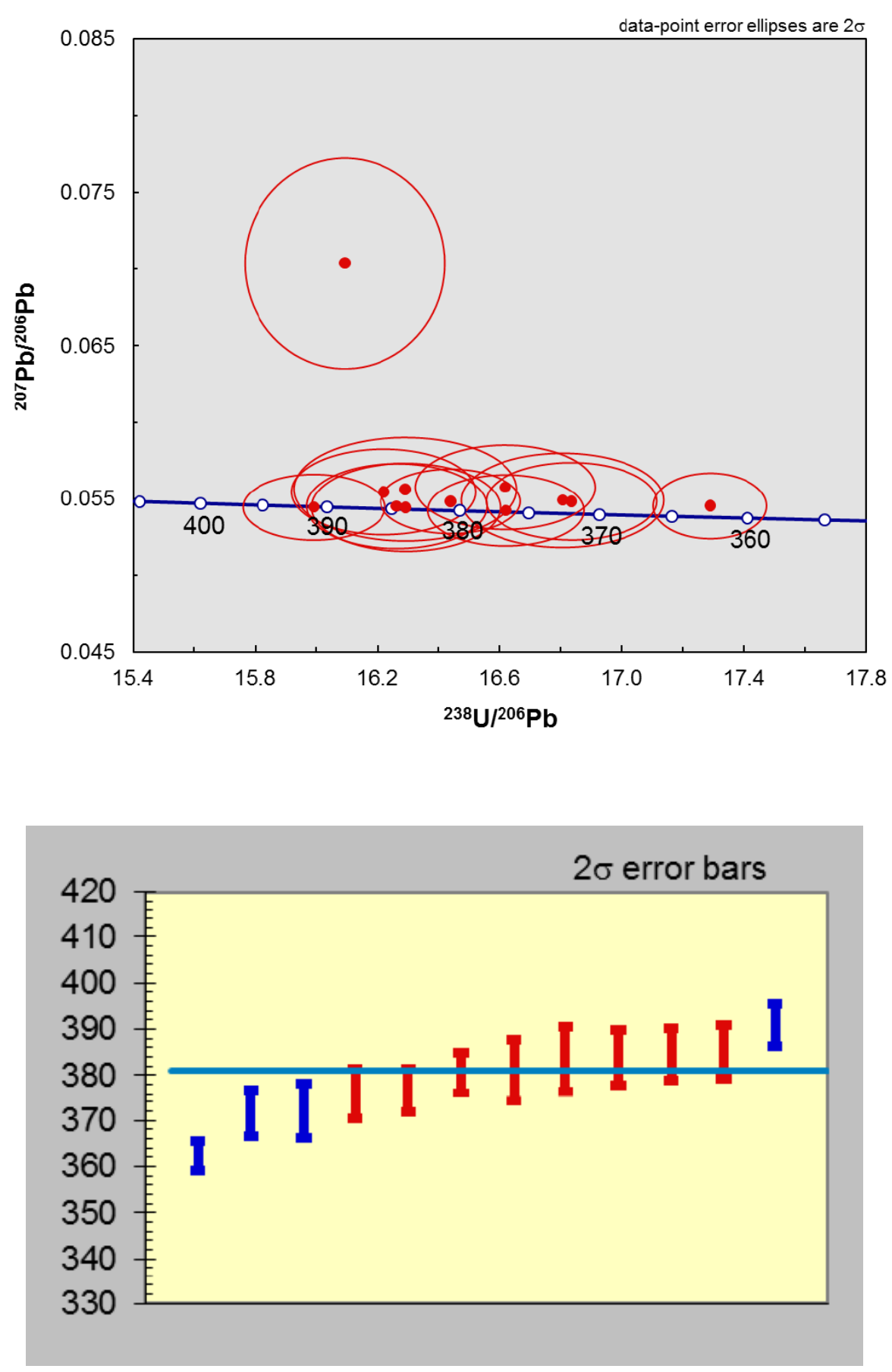


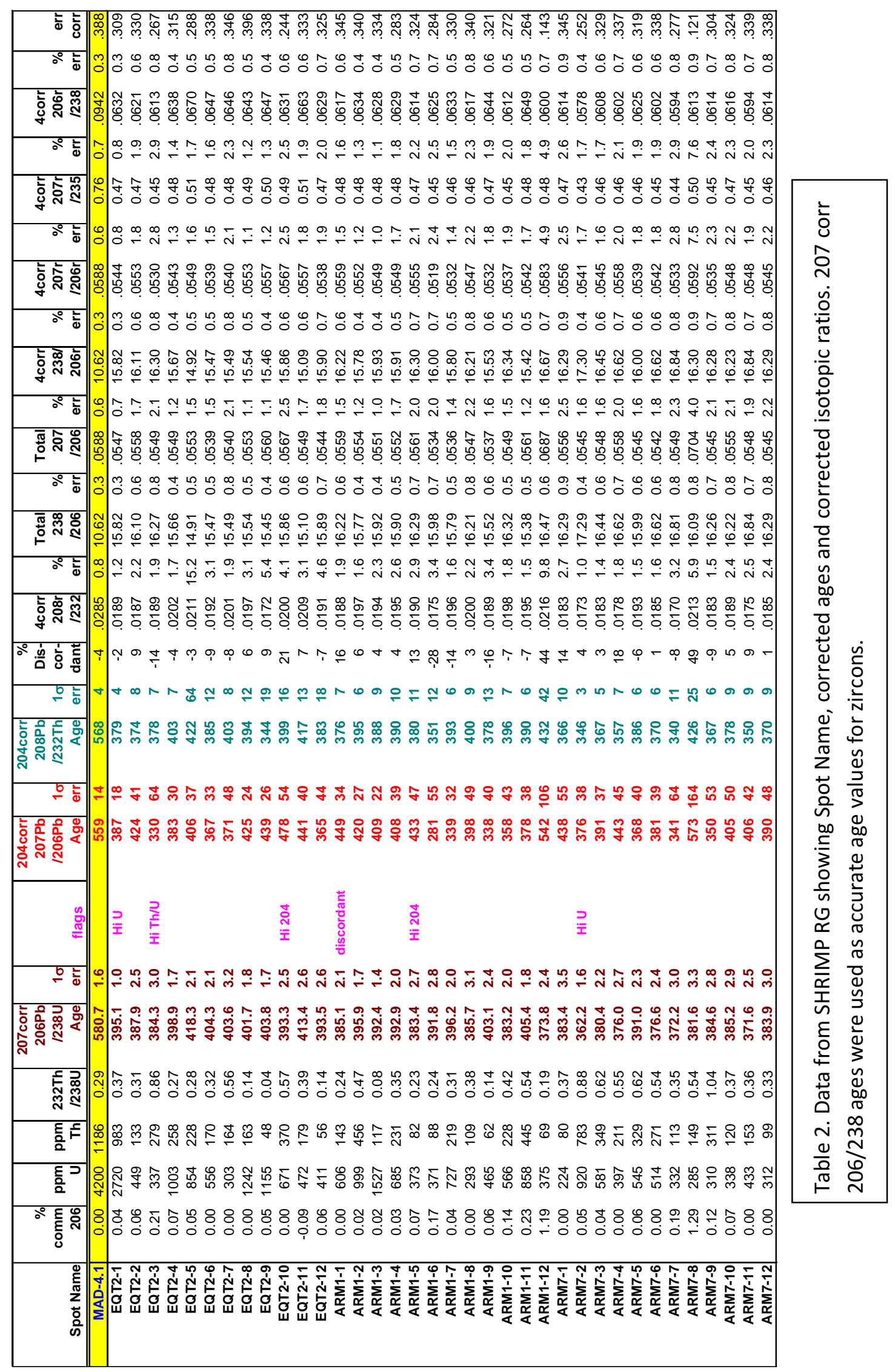




\begin{tabular}{|c|c|c|}
\hline$\frac{2}{2}$ & 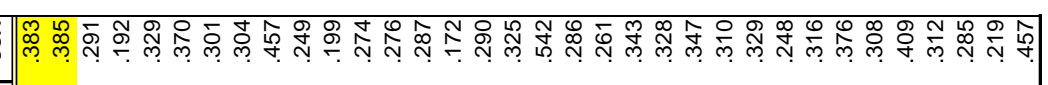 & \\
\hline$\delta^{\circ}$ & 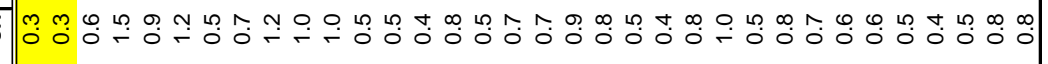 & \\
\hline & 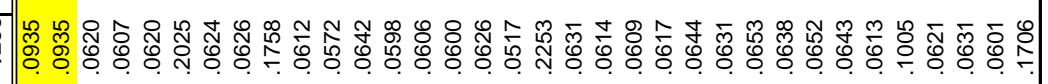 & \\
\hline & 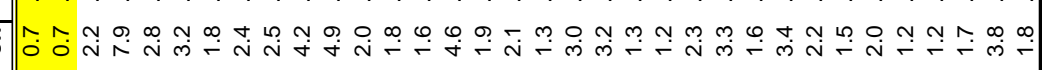 & \\
\hline & 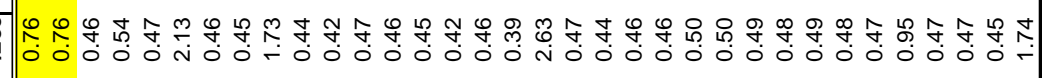 & \\
\hline & 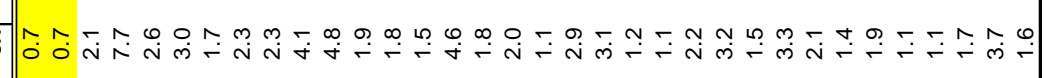 & \\
\hline 辛 & 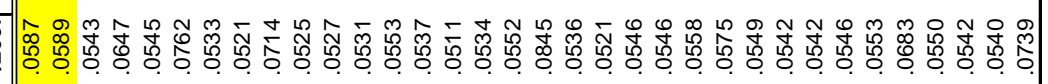 & \\
\hline & 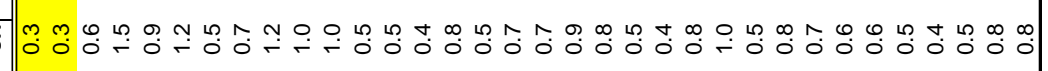 & \\
\hline & 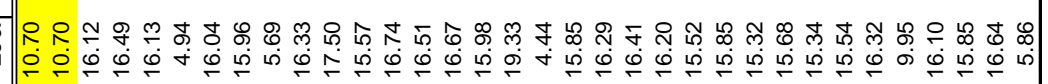 & \\
\hline & 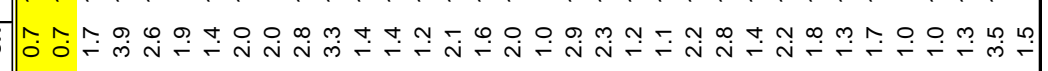 & \\
\hline & 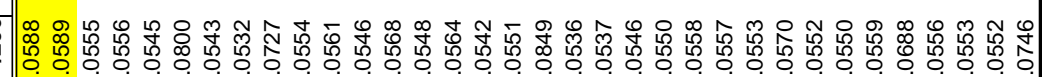 & \\
\hline & 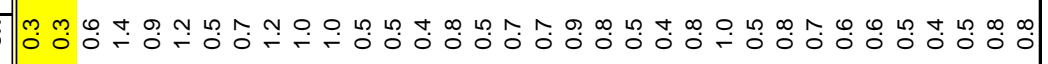 & \\
\hline & 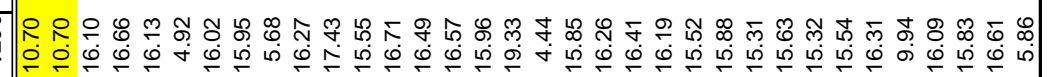 & \\
\hline & 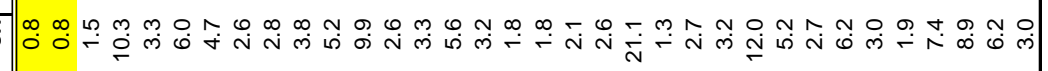 & \\
\hline & 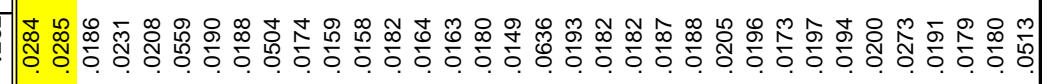 & \\
\hline 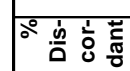 & W & \\
\hline & 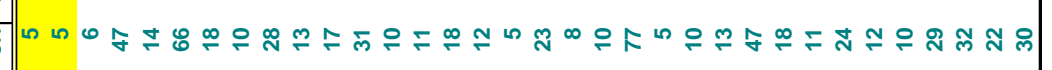 & \\
\hline 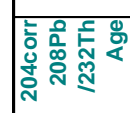 & 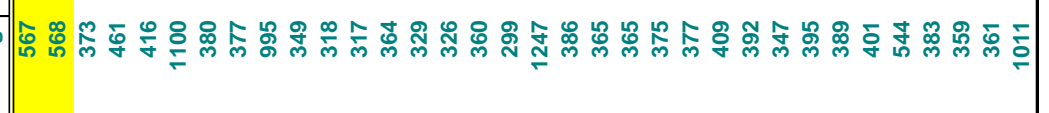 & \\
\hline & 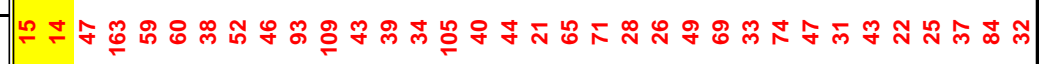 & \\
\hline 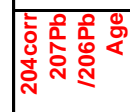 & 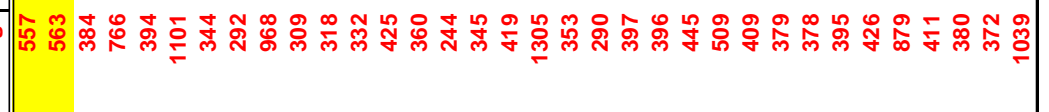 & \\
\hline & 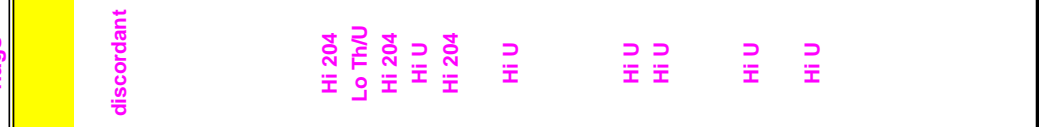 & \\
\hline$\frac{b}{6}$ & 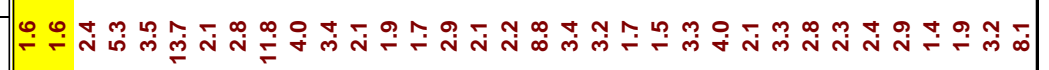 & \\
\hline 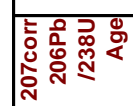 & 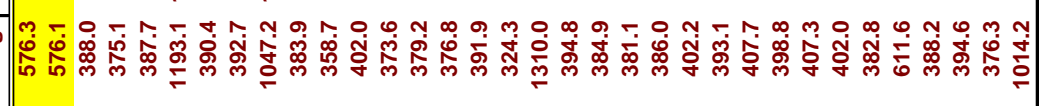 & \\
\hline 趂 & $\mid$ & \\
\hline$\frac{\varepsilon_{2}}{2} F$ & 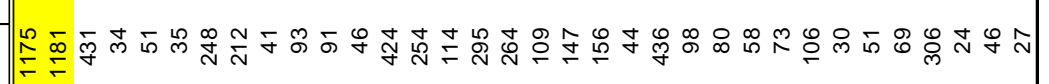 & $\dot{\sim}$ \\
\hline$\frac{\varepsilon}{2}_{2}^{J}$ & 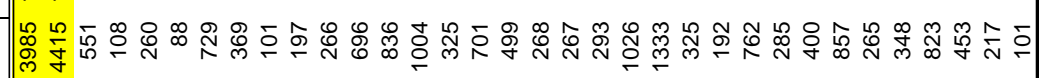 & $\frac{0}{0}$ \\
\hline 을 & 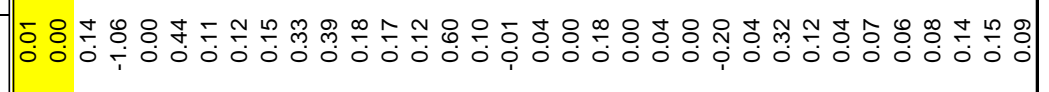 & $\stackrel{\text { L }}{\xi}$ \\
\hline & 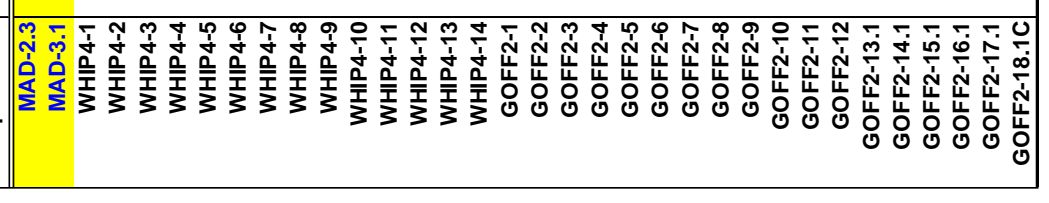 & 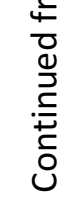 \\
\hline
\end{tabular}




\begin{tabular}{|c|c|}
\hline 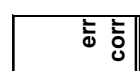 & 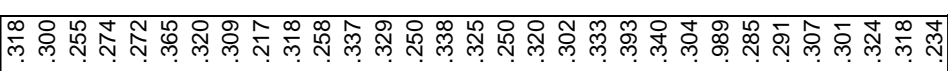 \\
\hline $\bar{t}$ & 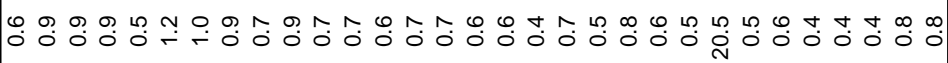 \\
\hline & 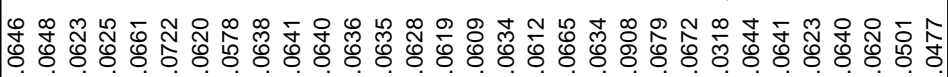 \\
\hline e to & 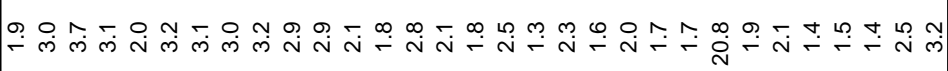 \\
\hline & 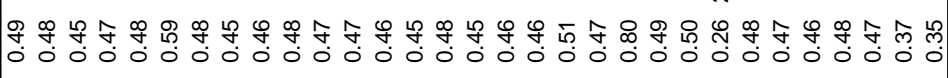 \\
\hline & 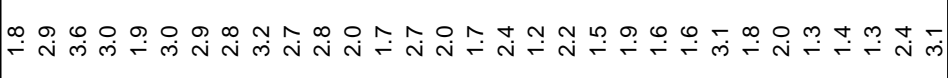 \\
\hline & 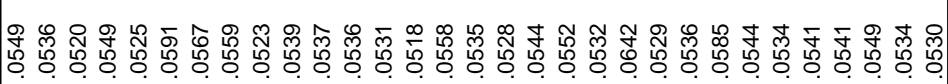 \\
\hline t.t. & 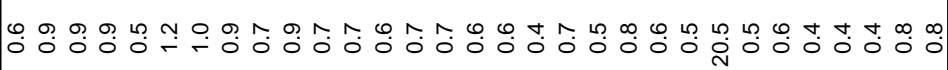 \\
\hline & 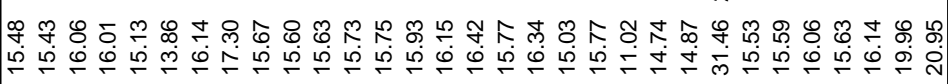 \\
\hline & 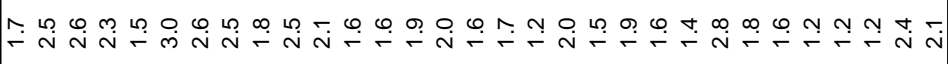 \\
\hline & 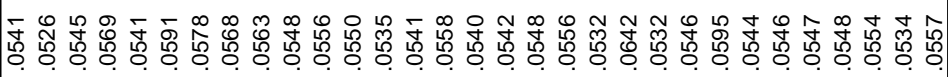 \\
\hline & 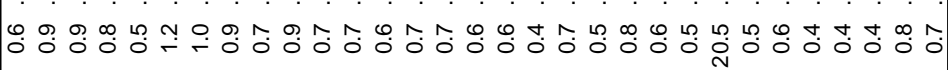 \\
\hline 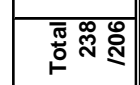 & 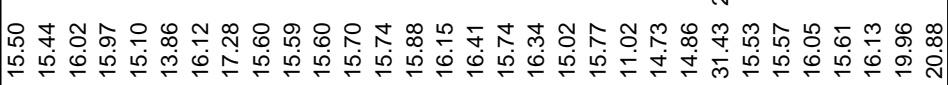 \\
\hline & m్ \\
\hline & 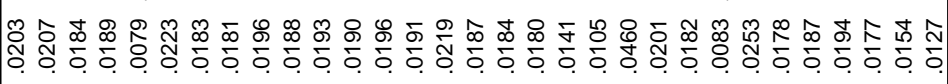 \\
\hline 它咅葍 & 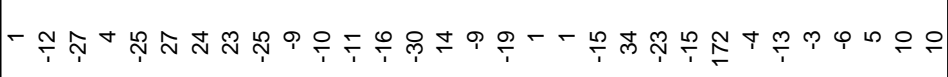 \\
\hline & 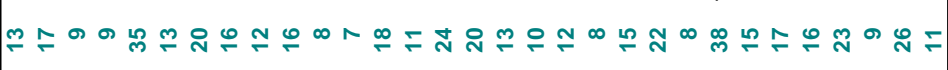 \\
\hline & 車考品 \\
\hline & Ғ \\
\hline & 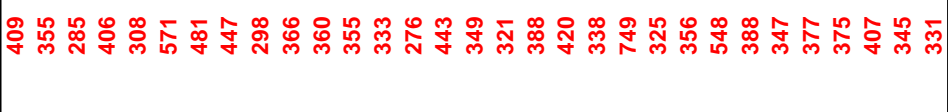 \\
\hline 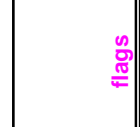 & 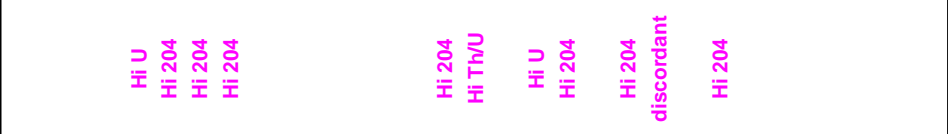 \\
\hline $2 \frac{1}{0}$ & đ̊ \\
\hline & 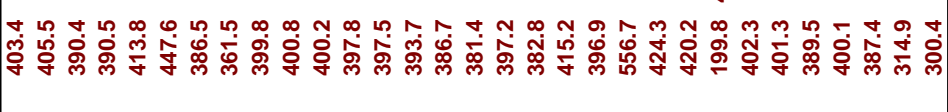 \\
\hline 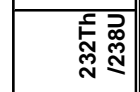 & 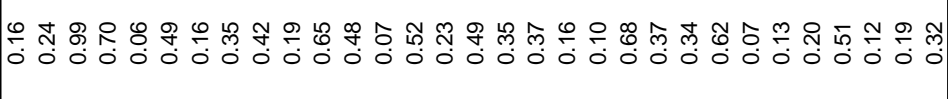 \\
\hline$\frac{E}{2} F$ & 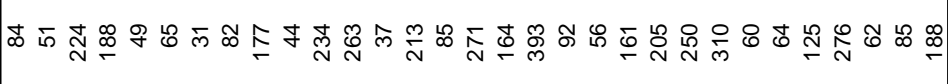 \\
\hline$\frac{\varepsilon_{0}}{2}$ & 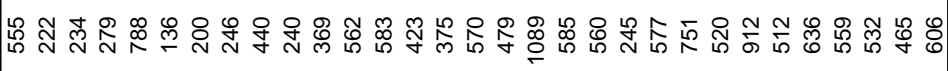 \\
\hline 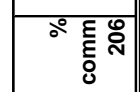 & 車 \\
\hline \begin{tabular}{l|l}
$\frac{\pi}{2}$ \\
$\frac{0}{0}$ \\
के
\end{tabular} & 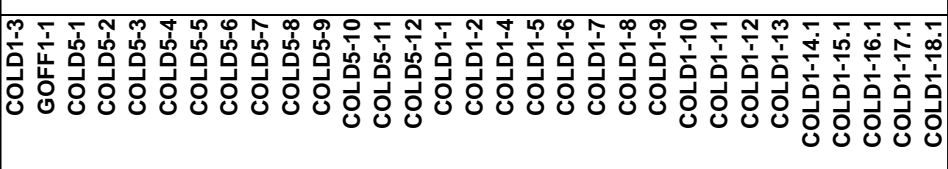 \\
\hline
\end{tabular}




\begin{tabular}{|c|c|}
\hline to & 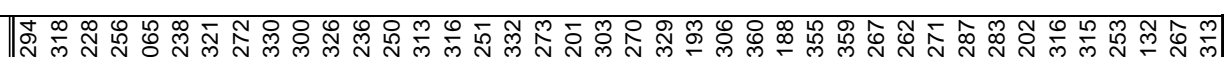 \\
\hline $0^{\circ} \bar{\vdots}$ & 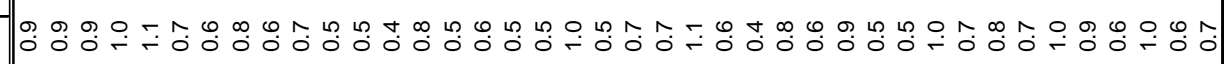 \\
\hline 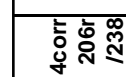 & 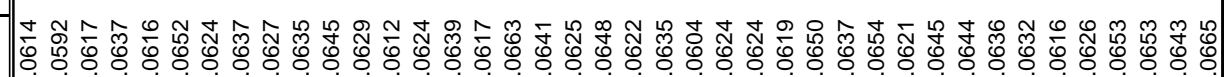 \\
\hline & $\mid$ \\
\hline 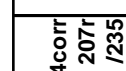 & 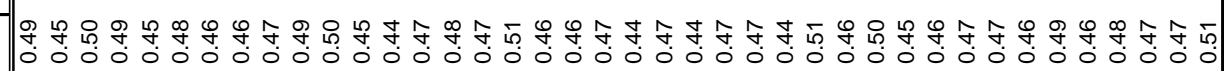 \\
\hline$\circ \overline{0}$ & 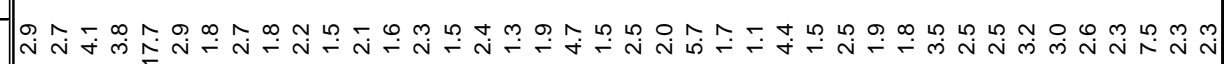 \\
\hline & 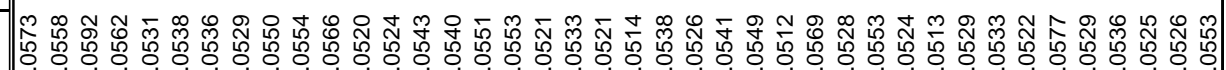 \\
\hline & $\mid$ \\
\hline 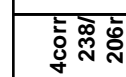 & 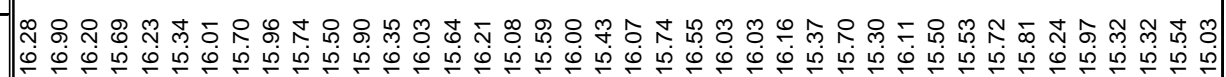 \\
\hline & 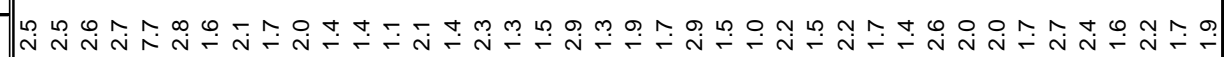 \\
\hline 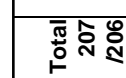 & 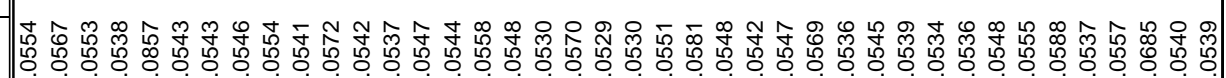 \\
\hline ¿ & 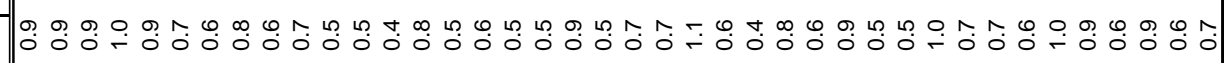 \\
\hline 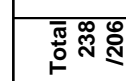 & 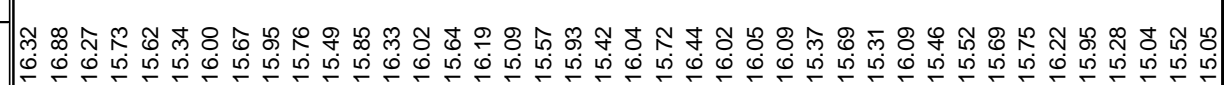 \\
\hline & 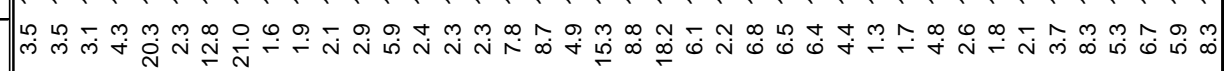 \\
\hline 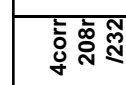 & 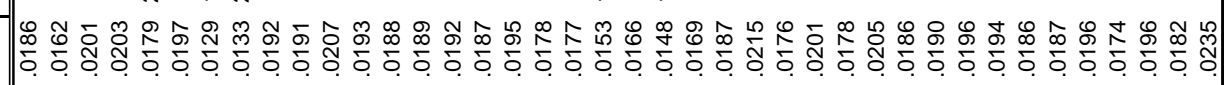 \\
\hline 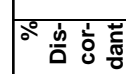 & 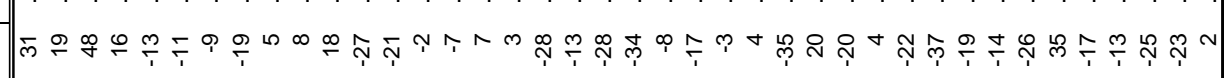 \\
\hline$\div \frac{b}{2}$ & 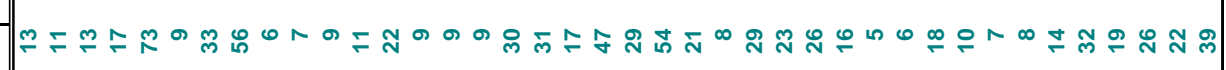 \\
\hline 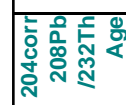 & 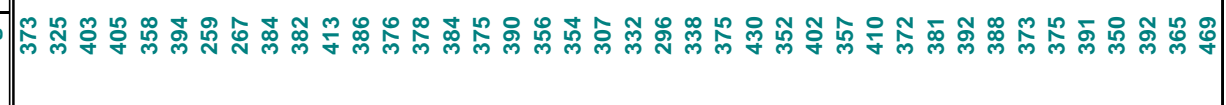 \\
\hline & 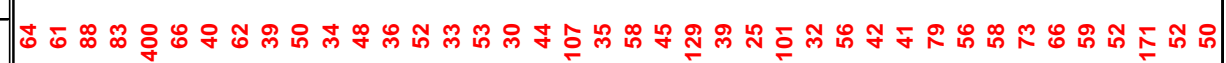 \\
\hline 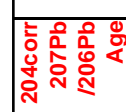 & 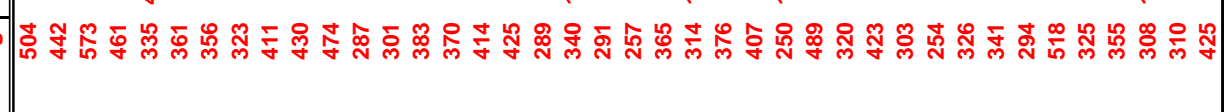 \\
\hline & 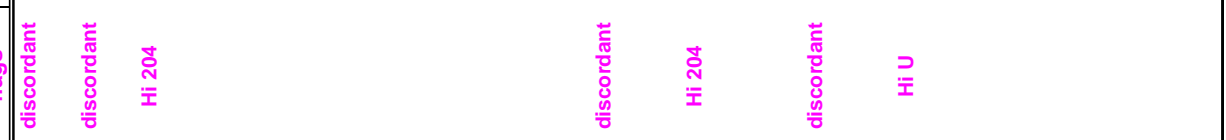 \\
\hline$\div \frac{1}{6}$ & 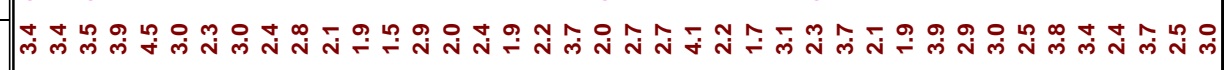 \\
\hline 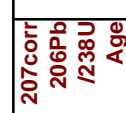 & 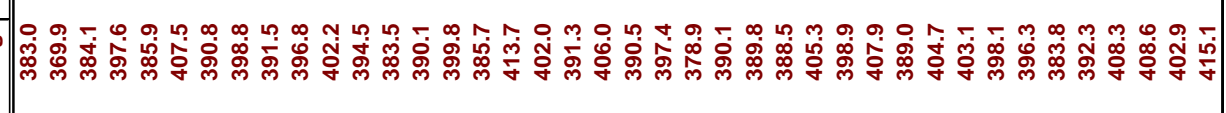 \\
\hline 듀묘 & 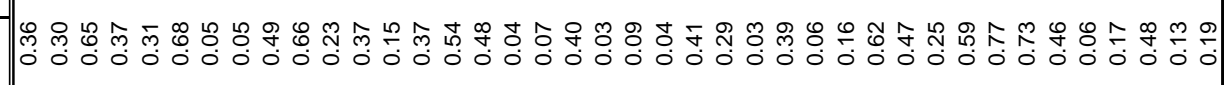 \\
\hline$\frac{E}{2} F$ & 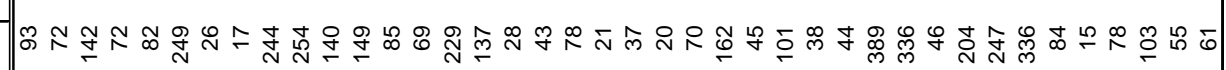 \\
\hline$\varepsilon_{0}^{2}$ & 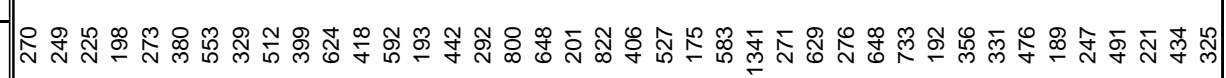 \\
\hline 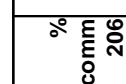 & 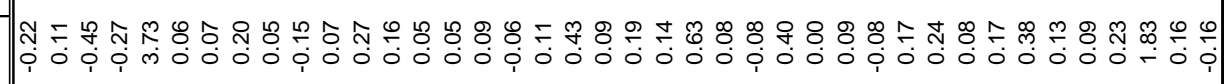 \\
\hline & 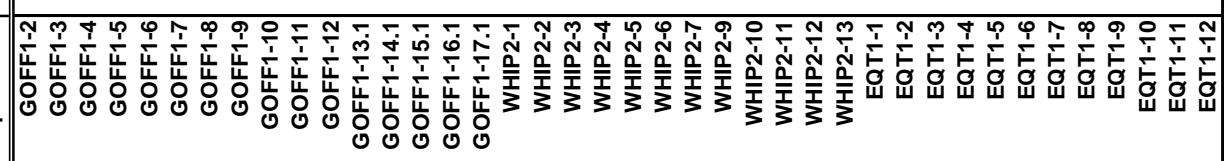 \\
\hline
\end{tabular}




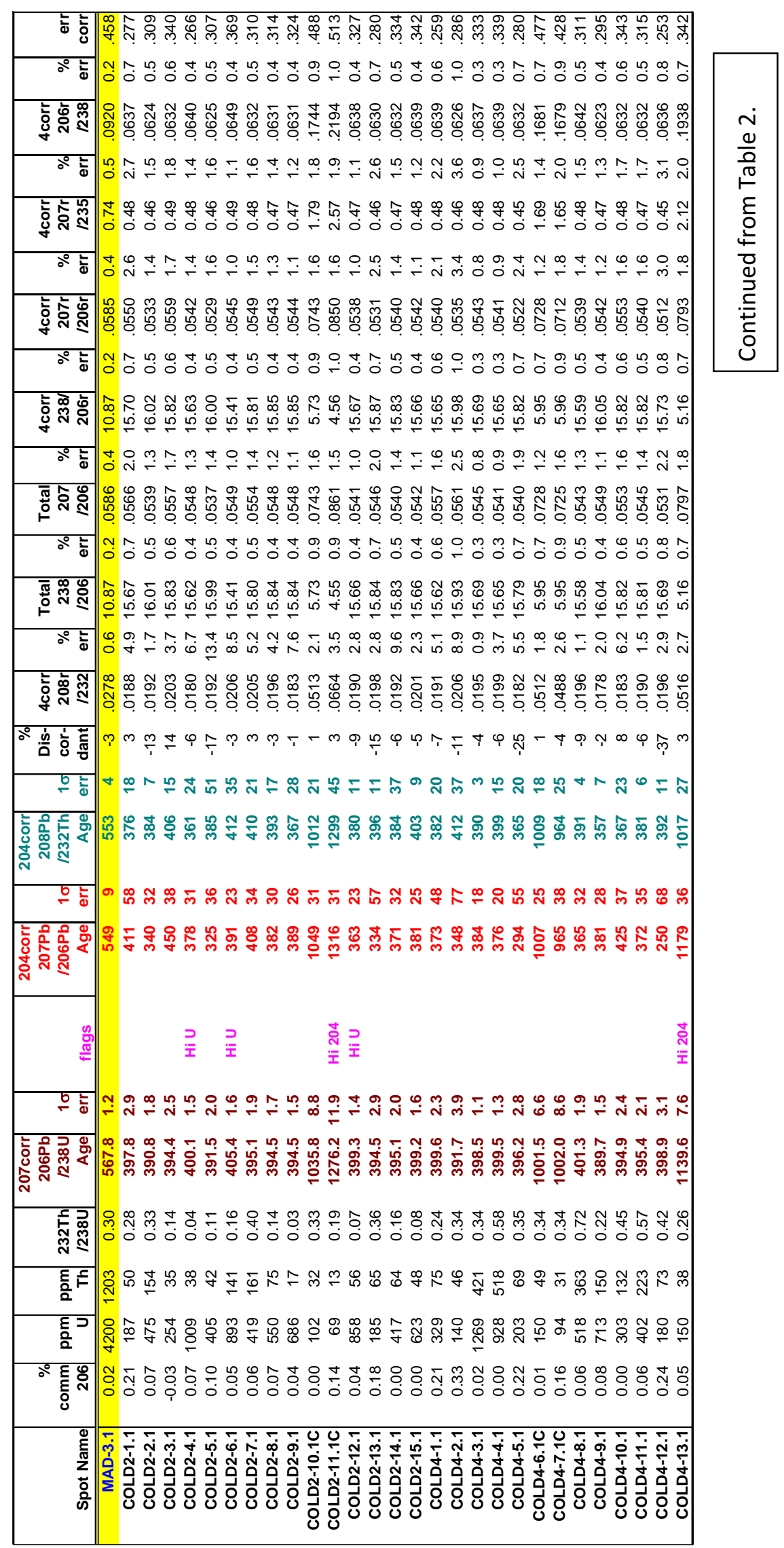




\begin{tabular}{|c|c|}
\hline 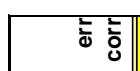 & 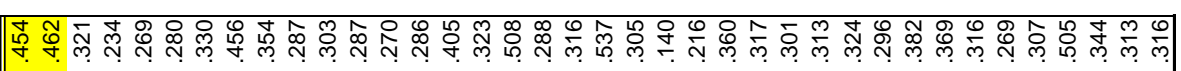 \\
\hline 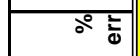 & 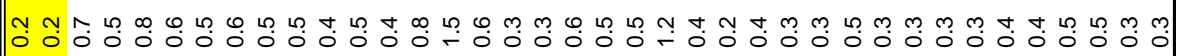 \\
\hline & 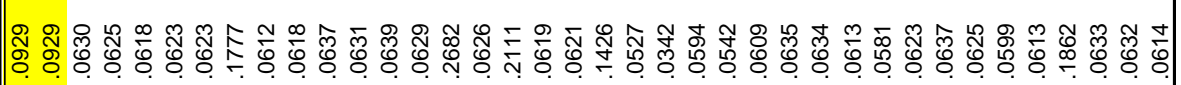 \\
\hline & 冓 \\
\hline 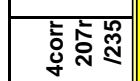 & 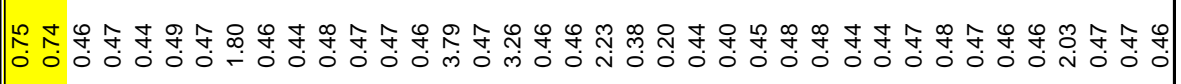 \\
\hline $\bar{t}$ & L \\
\hline & 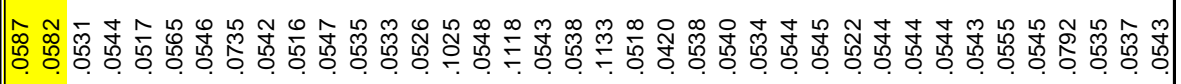 \\
\hline$\circ \div$ & 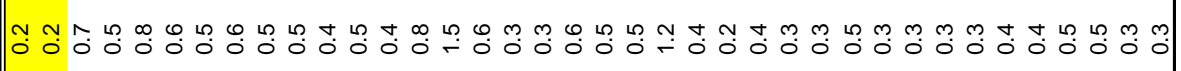 \\
\hline 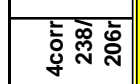 & 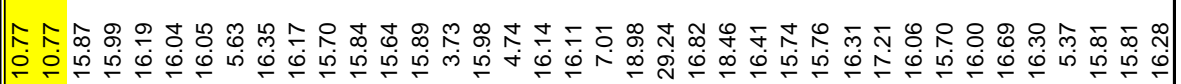 \\
\hline & 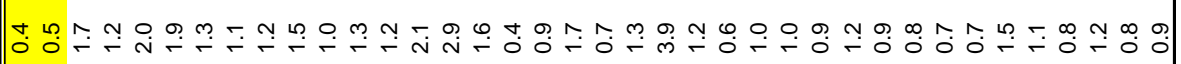 \\
\hline & 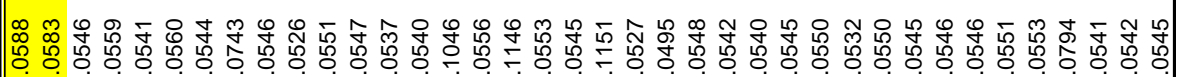 \\
\hline & 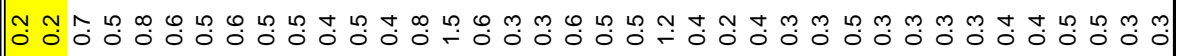 \\
\hline & 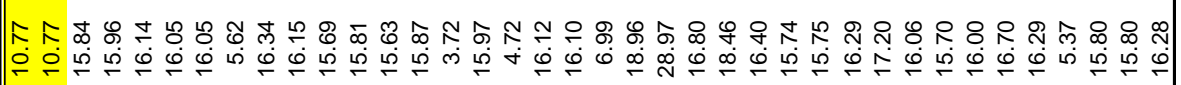 \\
\hline & 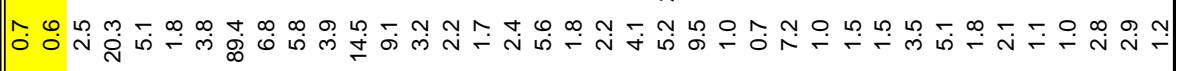 \\
\hline 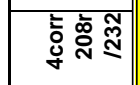 & 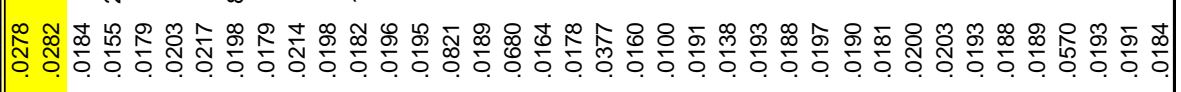 \\
\hline 它产莞 & 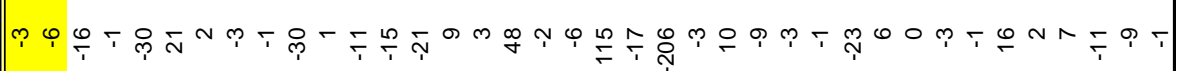 \\
\hline & ナナの \\
\hline 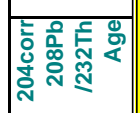 & 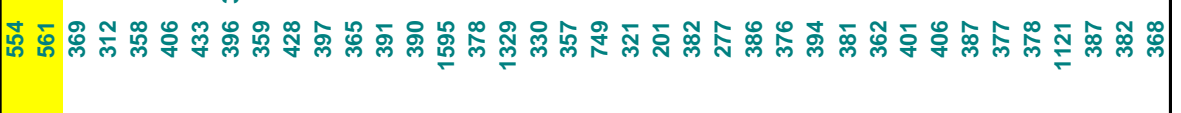 \\
\hline & 으웅 g \& \\
\hline 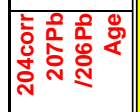 & 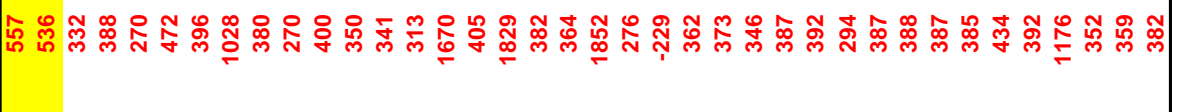 \\
\hline 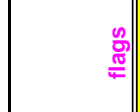 & 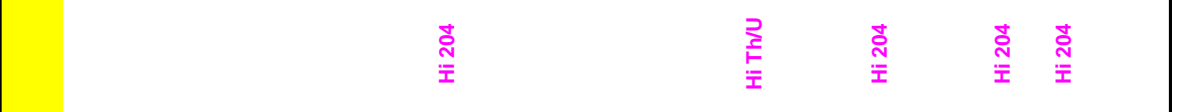 \\
\hline$\stackrel{\circ}{\circ}=$ & 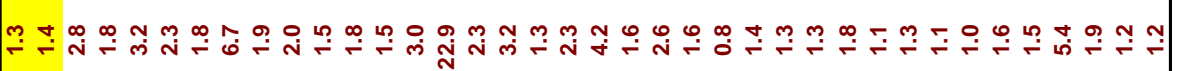 \\
\hline 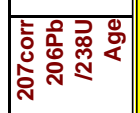 & 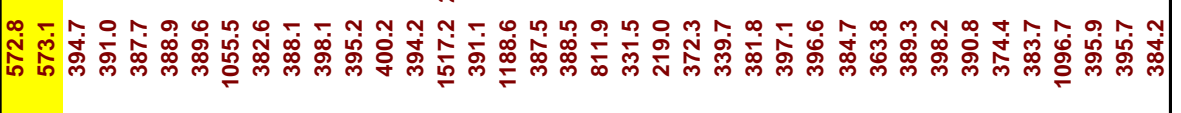 \\
\hline 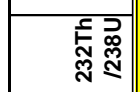 & 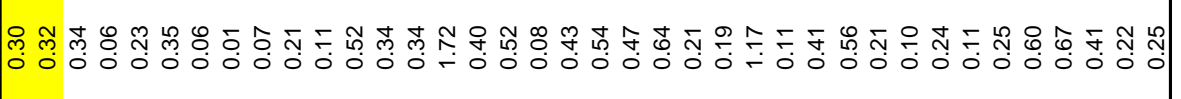 \\
\hline$\frac{E}{2} F$ & 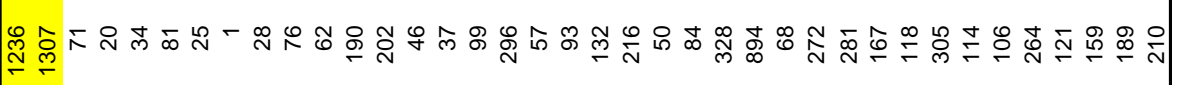 \\
\hline $\bar{\varepsilon}^{\underline{2}}$ & 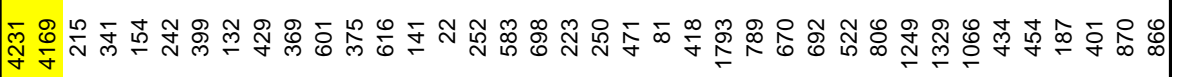 \\
\hline 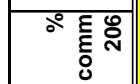 & 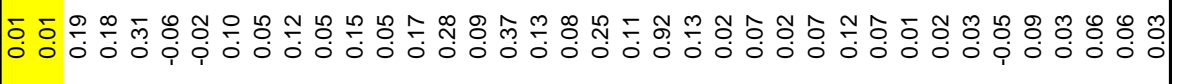 \\
\hline 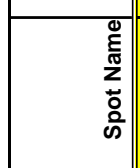 & 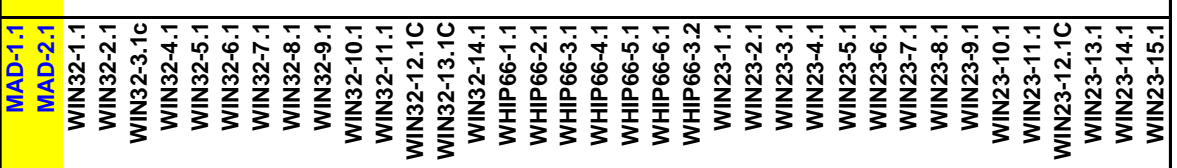 \\
\hline
\end{tabular}




\begin{tabular}{|c|c|}
\hline 它产 & 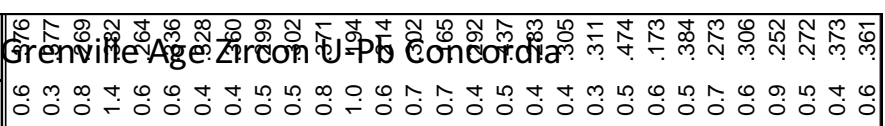 \\
\hline 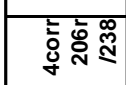 & 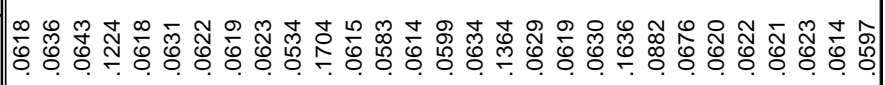 \\
\hline & 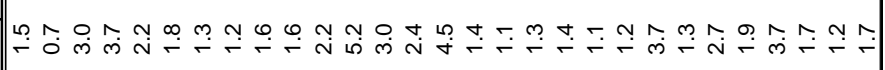 \\
\hline 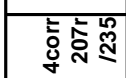 & 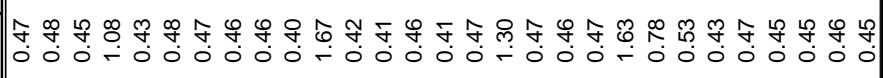 \\
\hline & 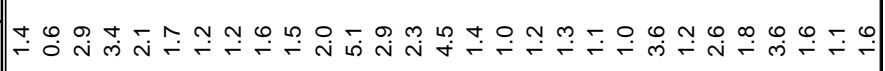 \\
\hline & 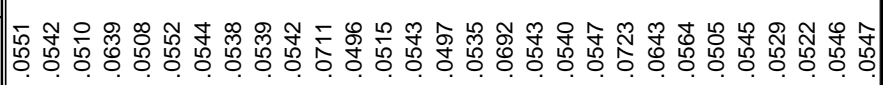 \\
\hline & 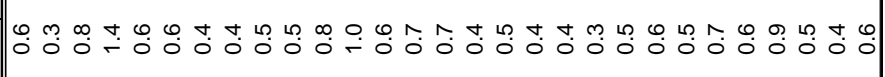 \\
\hline 容学 & 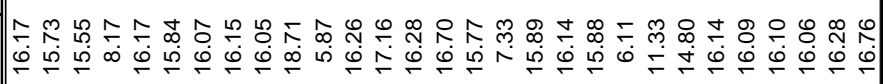 \\
\hline & 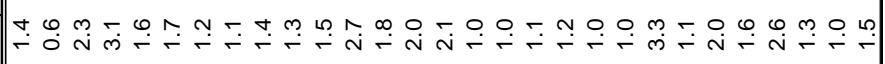 \\
\hline & 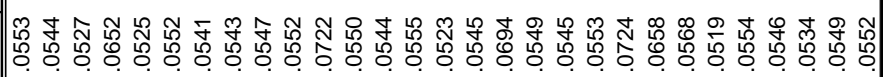 \\
\hline & 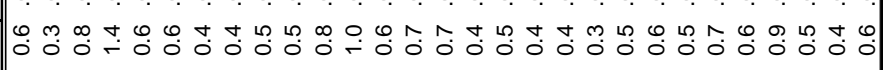 \\
\hline & 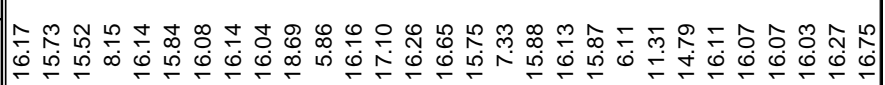 \\
\hline & 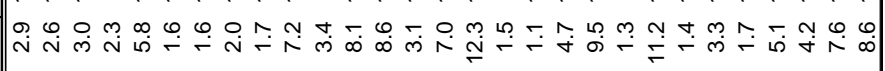 \\
\hline & 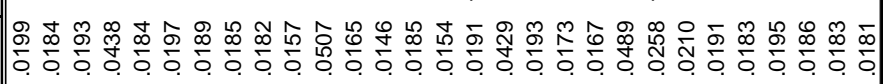 \\
\hline 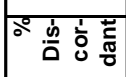 & 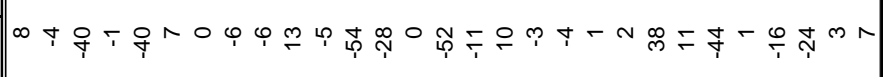 \\
\hline & 누우 ㅈㅅ \\
\hline 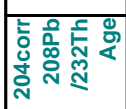 & 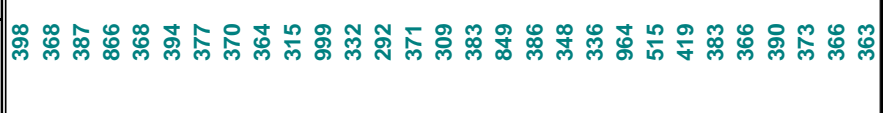 \\
\hline & 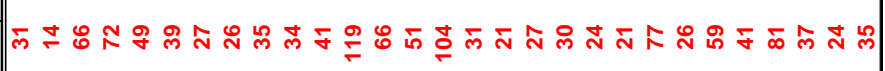 \\
\hline 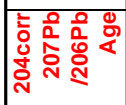 & 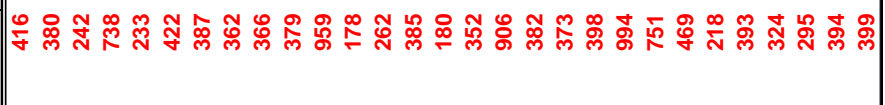 \\
\hline 过 & $\underset{\substack{P \\
F}}{\stackrel{P}{I}}$ \\
\hline & 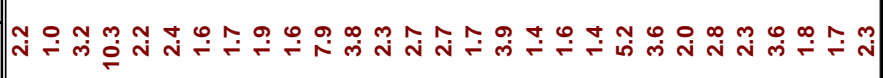 \\
\hline 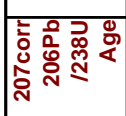 & 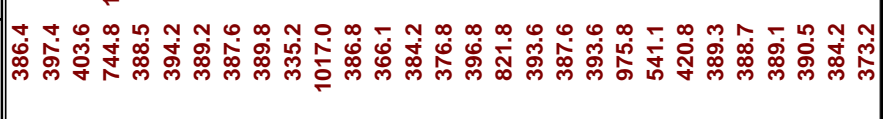 \\
\hline 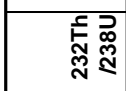 & 怤 \\
\hline$\frac{E}{E} \overline{2}$ & 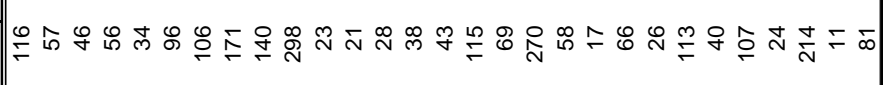 \\
\hline${\frac{g_{0}}{2}}^{J}$ & 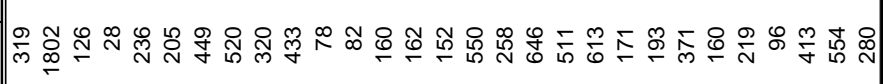 \\
\hline 응 & 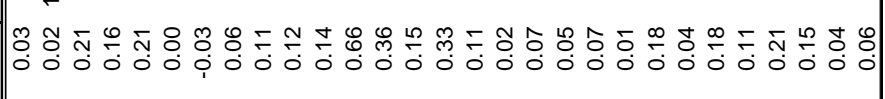 \\
\hline $\begin{array}{l} \\
\frac{1}{2} \\
\frac{\pi}{2} \\
\text { के }\end{array}$ & 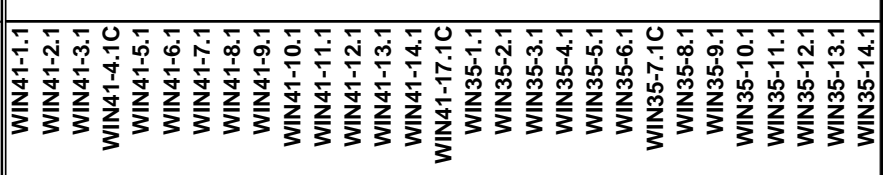 \\
\hline
\end{tabular}


Grenville age zircons:

\begin{tabular}{|c|c|c|c|c|c|c|c|c|c|c|c|c|}
\hline Spot Name & $\begin{array}{c}\% \\
\text { comm } \\
206\end{array}$ & $\begin{array}{c}\text { ppm } \\
\text { U }\end{array}$ & $\begin{array}{c}\text { ppm } \\
\text { Th }\end{array}$ & $\begin{array}{l}232 \mathrm{Th} \\
\text { /238U }\end{array}$ & $\begin{array}{c}207 \text { corr } \\
206 \mathrm{~Pb} \\
/ 238 \mathrm{U} \\
\text { Age }\end{array}$ & $\begin{array}{l}1 \sigma \\
\text { err }\end{array}$ & flags & $\begin{array}{c}204 \text { corr } \\
207 \mathrm{~Pb} \\
/ 206 \mathrm{~Pb} \\
\text { Age }\end{array}$ & $\begin{array}{l}1 \sigma \\
\text { err }\end{array}$ & $\begin{array}{c}204 \text { corr } \\
208 \mathrm{~Pb} \\
/ 232 \mathrm{Th} \\
\text { Age }\end{array}$ & $\begin{array}{l}1 \sigma \\
\text { err }\end{array}$ & $\begin{array}{c}\% \\
\text { Dis- } \\
\text { cor- } \\
\text { dant }\end{array}$ \\
\hline WHIP4-4 & 0.44 & 88 & 35 & 0.41 & 1193.1 & 13.7 & & 1101 & 60 & 1100 & 66 & -7 \\
\hline WHIP4-7 & 0.15 & 101 & 41 & 0.42 & 1047.2 & 11.8 & & 968 & 46 & 995 & 28 & -7 \\
\hline GOFF2-2 & 0.04 & 268 & 109 & 0.42 & 1310.0 & 8.8 & & 1305 & 21 & 1247 & 23 & 0 \\
\hline GOFF2-18.1C & 0.09 & 101 & 27 & 0.28 & 1014.2 & 8.1 & & 1039 & 32 & 1011 & 30 & 2 \\
\hline COLD2-10.1C & 0.00 & 102 & 32 & 0.33 & 1035.8 & 8.8 & & 1049 & 31 & 1012 & 21 & 1 \\
\hline COLD2-11.1C & 0.14 & 69 & 13 & 0.19 & 1276.2 & 11.9 & Hi 204 & 1316 & 31 & 1299 & 45 & 3 \\
\hline COLD4-6.1C & 0.01 & 150 & 49 & 0.34 & 1001.5 & 6.6 & & 1007 & 25 & 1009 & 18 & 1 \\
\hline COLD4-7.1C & 0.16 & 94 & 31 & 0.34 & 1002.0 & 8.6 & & 965 & 38 & 964 & 25 & -4 \\
\hline COLD4-13.1 & 0.05 & 150 & 38 & 0.26 & 1139.6 & 7.6 & Hi 204 & 1179 & 36 & 1017 & 27 & 3 \\
\hline WIN32-6.1 & 0.10 & 132 & 1 & 0.01 & 1055.5 & 6.7 & & 1028 & 26 & 396 & 354 & -3 \\
\hline WIN32-13.1C & 0.28 & 22 & 37 & 1.72 & 1517.2 & 22.9 & Hi 204 & 1670 & 63 & 1595 & 35 & 9 \\
\hline WIN23-12.1C & 0.03 & 187 & 121 & 0.67 & 1096.7 & 5.4 & Hi 204 & 1176 & 17 & 1121 & 11 & 7 \\
\hline WIN41-11.1 & 0.14 & 78 & 23 & 0.31 & 1017.0 & 7.9 & & 959 & 41 & 999 & 34 & -5 \\
\hline
\end{tabular}

